UNIVERSIDADE DE SÃO PAULO

ESCOLA DE ENGENHARIA DE SÃO CARLOS

DEPARTAMENTO DE HIDRÁULICA E SANAMENTO

VINÍCIUS CARVALHO ROCHA

\title{
PROCESSAMENTO ANAERÓBIO DE VINHAÇA PRÉ-TRATADA COM BIOPOLÍMERO À BASE DE CÁLCIO
}

Dissertação apresentada à Escola de Engenharia de São Carlos, da Universidade de São Paulo, como parte dos requisitos para a obtenção do Título de Mestre em Ciências. Área de Concentração: Hidráulica e Saneamento

Orientador: Prof. Tit. Eduardo Cleto Pires

\section{VERSÃO CORRIGIDA}

São Carlos - SP 
AUTORIZO A REPRODUÇÃO E DIVULGAÇÃO TOTAL OU PARCIAL DESTE TRABALHO, POR QUALQUER MEIO CONVENCIONAL OU ELETRÔNICO, PARA FINS DE ESTUDO E PESQUISA, DESDE QUE CITADA A FONTE.

Ficha catalográfica preparada pela Seção de Tratamento da Informação do Serviço de Biblioteca - EESC/USP

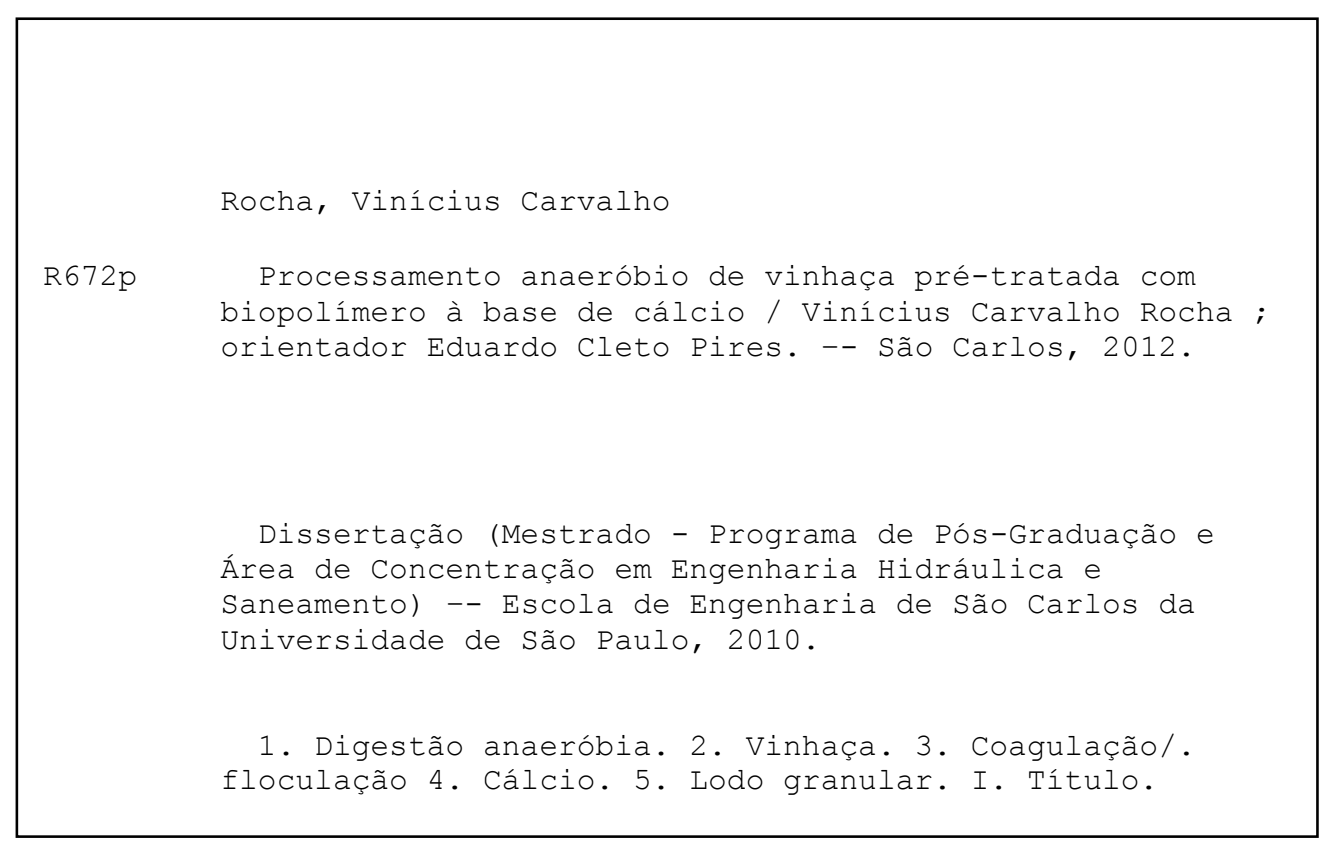




\section{FOLHA DE JULGAMENTO}

\section{Candidato: Engenheiro VINÍCIUS CARVALHO ROCHA.}

Título da dissertação: "Processamento anaeróbio de vinhaça pré-tratada com biopolímero à base de cálcio".

Data da defesa: 04/05/2012

\section{Comissão Julgadora:}

Prof. Titular Eduardo Cleto Pires (Orientador)

(Escola de Engenharia de São Carlos/EESC)

Prof ${ }^{ \pm}$. Drª , Márcia Helena Rissato Zamariolli Damianovic (Escola de Engenharia de São Carlos/EESC)

Prof ${ }^{2}$. Dri ${ }^{-1}$. Giovana Tommaso

(Faculdade de Zootecnia e Engenharia de Alimentos/USP)
Resultado:
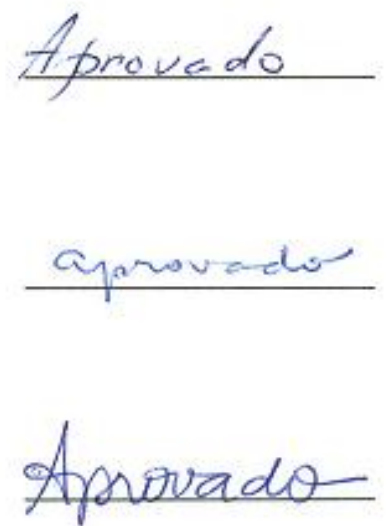

Coordenador do Programa de Pós-Graduação em Engenharia Hidráulica e Saneamento:

Prof. Titular Edson Cezar Wendland

Presidente da Comissão de Pós-Graduação:

Prof. Associado Paulo Cesar Lima Segantine 

"Experiência é o nome que nós damos aos nossos próprios erros.”

Oscar Wilde

"Uma experiência nunca é um fracasso, pois sempre vem demonstrar algo."

Thomas A. Edison

Dedico esta experiência a meus pais, Marta e Vanderlande. 



\section{AGRADECIMENTOS}

Agradeço a Deus por sempre me iluminar e me guiar por onde eu percorra meu caminho.

À minha família que sempre me apoiou e me deu força para continuar a batalhar e conseguir o sucesso. Obrigado Marta e Vanderlande, exemplos de paz, carinho e amor. Obrigado, também, aos meus irmãos Marcelo e Henrique, que sempre me apoiaram, mesmo à distância.

Ao Professor Dr. Eduardo Cleto Pires, pela excelente orientação, confiança, amizade e atenção dada em todos os momentos que foram necessários.

À Professora Márcia Damianovic pelas incontáveis contribuições materiais e intelectuais. Obrigado pela amizade e orientação.

À minha namorada Aline, que sempre me apoiou e incentivou durante todo o período da pesquisa, e também me ajudou com os desenhos em CAD.

Às técnicas Janja, Isabel e Maria Teresa pelo apoio técnico em todos os momentos em que precisei.

Às funcionárias do SHS, Sá, Pavi e Rose, que sempre estiveram ajudando-nos a resolver nossos problemas burocráticos.

Aos meus amigos Leandro, Marjolly, Dico, Piu, Lênin, Priscila, Gustavo, Txê, Osvaldo, Samuel, Rudner, Dr. Ivan, Marisco, Madruga, Mineiro, Murillo, Montanha e todos que não citei, mas têm papel importante nesta conquista. Ao pessoal do futebol semanal pela ótima companhia dentro e fora da universidade. E não pode faltar agradecer nossa querida cadelinha, Zupa, que é a alegria de todo mundo!

À FAPESP pelo financiamento da pesquisa por meio do projeto temático.

À CAPES e CNPq pela bolsa concedida durante o mestrado. 



\section{RESUMO}

ROCHA, V. C. Processamento Anaeróbio de Vinhaça Pré-tratada com Biopolímero à Base de Cálcio. 2012. 104 F. Dissertação (Mestrado) - Escola de Engenharia de São Carlos, Departamento de Hidráulica e Saneamento, Universidade de São Paulo, São Carlos. 2012.

O objetivo principal desta pesquisa foi comparar o desempenho de dois reatores anaeróbios híbridos de biomassa e imobilizada (RAHBI), em escala de laboratório, no processamento de vinhaça de cana-de-açúcar. Um (reator 1) recebendo vinhaça sem tratamento prévio e outro (reator 2) processando vinhaça previamente submetida à coagulação, utilizando-se de um biopolímero experimental a base de cálcio. Os reatores foram construídos em acrílico, com volume de 1,5 litros cada, provido de sistema de recirculação com razão igual a 3. A operação dos reatores foi dividida em duas etapas: a primeira, com duração de 69 dias, teve seu fim caracterizado por um colapso apresentado pelo reator 2. A segunda fase, com duração de 37 dias, onde se observou outro colapso. O principal parâmetro de controle no monitoramento dos reatores foi a quantificação de matéria orgânica, em termos de Demanda Química de Oxigênio (DQO). Durante a Fase I, o reator 1 apresentou eficiência de remoção média de 82,9 $\pm 4,4 \%$, e o reator 2 de $72,2 \pm 18,1 \%$. A carga orgânica volumétrica (COV) média aplicada para o reator 1 , durante esta fase, foi de $5,3 \pm 1,3 \mathrm{~kg}$ DQO $/ \mathrm{m}^{3} \mathrm{~d}$, e para o reator 2 foi de $5,3 \pm$ $1,6 \mathrm{~kg} \mathrm{DQO} / \mathrm{m}^{3} \mathrm{~d}$. O colapso ocorrido no reator 2 foi evidenciada pelo decréscimo acentuado da eficiência de remoção, chegando a 33,7\%. Durante a Fase II, o reator 1 apresentou eficiência de remoção média de 77,5 $\pm 9,4 \%$, e o reator 2 de 79,2 $\pm 9,7 \%$. A carga orgânica volumétrica $(\mathrm{COV})$ média aplicada para o reator 1 , durante esta fase, foi de $5,1 \pm 2,4 \mathrm{~kg}$ $\mathrm{DQO} / \mathrm{m}^{3} \mathrm{~d}$, e para o reator 2 foi de $5,0 \pm 2,3 \mathrm{~kg} \mathrm{DQO} / \mathrm{m}^{3} \mathrm{~d}$. Ao final desta fase o reator 1 apresentou eficiência de remoção de $80,9 \%$, e o reator $265.8 \%$. Foram analisados, também, alcalinidade e produção de metano $\left(\mathrm{CH}_{4}\right)$. Durante todas as fases, a alcalinidade dos dois reatores esteve acima de $1000 \mathrm{mg} \mathrm{CaCO}_{3} / \mathrm{l}$, indicando estabilidade, em relação a este parâmetro, dos reatores. A produção de $\mathrm{CH}_{4}$ do reator 1 foi de $0,0507 \pm 0,02321 \mathrm{CH}_{4} / \mathrm{h}$ e $0,0838 \pm 0,0326 \mathrm{l} \mathrm{CH}_{4} / \mathrm{h}$ nas fases I e II, respectivamente. Para o reator 2, esta produção foi de $0,0307 \pm 0,0137 \mathrm{l} \mathrm{CH}_{4} / \mathrm{h}$ e $0,08 \pm 0,0297 \mathrm{l} \mathrm{CH}_{4} / \mathrm{h}$, para as fases I e II, respectivamente. Foram feitos ensaios de resistência mecânica dos grânulos, análise de microscopia eletrônica de varredura (MEV), Espectrometria de Energia Dispersiva de Raios-X (EDS) e análise da comunidade microbiana, empregando técnicas de biologia molecular. Os testes de resistência mecânica dos grânulos indicam que os grânulos contidos no inóculo, reatores 1 e 2 possuíam resistência à desintegração. As análises de MEV e EDS indicam a presença do elemento cálcio com aproximadamente $22 \%$ para o inóculo, $39 \%$ para o reator 1 e $50 \%$ para o reator 2 , na massa dos elementos analisados das amostras de grânulos. As análises de biologia molecular indicaram similaridades entre os reatores 1 e 2 de 66,5 e $58 \%$, para os domínios Bacteria e Archaea, respectivamente. Desta forma, supõe-se que esta diferença da biota entre os reatores não estaria contribuindo para a falha ocorrida no reator 2 .

Palavras-chave: Vinhaça, digestão anaeróbia, coagulação/floculação, cálcio, lodo granular. 


\begin{abstract}
ROCHA, V. C. Anaerobic Processing of Vinasse Pre-treated with Biopolymer-Based Calcium. 2012. 104 F. Dissertation (Master's Degree) - Department of Hydraulic and Sanitation, School of Engineering of São Carlos, University of São Paulo, São Carlos, 2012.
\end{abstract}

This research aimed to compare the performance of two hybrid anaerobic immobilized biomass reactors (HAIB), in laboratory scale, processing vinasse from a sugar cane alcohol distillery. Reactor 1 received vinasse without pre-treatment. Reactor 2 processed coagulated vinasse using a calcium-based biopolymer as coagulant. The two reactors were built in acrylic, with a volume of 1,5 liters each. The recirculation flow rate was 3 . The operation of the reactors was divided in two phases: first, lasting 69 days, came to an end characterized by a failure (collapse) presented by the reactor 2 . The second phase, lasting 37 days, came to an end characterized by another collapse. The main control parameter in the monitoring of the reactors was the quantification of organic matter in terms of COD. During Phase I, the reactor 1 showed average removal efficiency of $82,9 \pm 4,4 \%$, and the reactor $272,2 \pm 18,1 \%$. The average organic loading rate (VOC) applied to reactor 1, during this phase, was $5,3 \pm 1,3 \mathrm{~kg}$ $\mathrm{DQO} / \mathrm{m}^{3} \mathrm{~d}$, and $5,3 \pm 1,6 \mathrm{~kg} \mathrm{DQO} / \mathrm{m}^{3} \mathrm{~d}$ for the reactor 2 . The failure occurred in the reactor 2 was evidenced by the sharp decrease of removal efficiency, reaching 33.7\%. During Phase II, the reactor 1 showed average removal efficiency of 77,5 $\pm 9,4 \%$, and the reactor $279,2 \pm 9,7$ $\%$. The average VOC applied to reactor 1, during this phase, was $5,1 \pm 2,4 \mathrm{~kg} \mathrm{DQO} / \mathrm{m}^{3} \mathrm{~d}$, and $5,0 \pm 2,3 \mathrm{~kg} \mathrm{DQO} / \mathrm{m}^{3} \mathrm{~d}$ for reactor 2 . At the end of this phase, the reactor 1 showed a removal efficiency of $80.9 \%$, and the reactor $265.8 \%$. Has also been analyzed, alkalinity and methane $\left(\mathrm{CH}_{4}\right)$. During all the phases, the alkalinity of both reactors was above $1000 \mathrm{mg} \mathrm{CaCO} / \mathrm{l}$, indicating stability in the reactors. The production of $\mathrm{CH}_{4}$ was $0,0507 \pm 0,02321 \mathrm{CH}_{4} / \mathrm{h}$ and $0,0326 \pm 0,08381 \mathrm{CH}_{4} / \mathrm{h}$ in phases I and II, respectively. For the reactor 2 , the production of $\mathrm{CH}_{4}$ was $0,0307 \pm 0,01371 \mathrm{CH}_{4} / \mathrm{h}$ e $0,08 \pm 0,02971 \mathrm{CH}_{4} / \mathrm{h}$ for the phases I and II, respectively. Assays were performed in mechanical granules strength, analysis of scanning electron microscopy (SEM), Energy Dispersive Spectroscopy X-ray (EDS) and analysis of the microbial community, using molecular biology techniques. The tests of mechanical of granules strength indicate that the granules contained in the inoculum, reactors 1 and 2 were resistant to disintegration. The SEM and EDS analysis indicated the presence of calcium element with approximately $22 \%$ inoculum, $39 \%$ for reactor 1 and $50 \%$ for reactor 2 , in the mass of the elements analyzed samples of granules. The microbial community analyzes indicated molecular similarity between the first and second reactor of 66,5 and $58 \%$ for Bacteria and Archaea domain, respectively. Thus, it is assumed that the difference between the biota of the reactors would not be contributing to the failure occurred in the reactor 2 .

Keywords: Vinasse, anaerobic digestion, coagulation / flocculation, calcium, granular sludge. 


\section{LISTA DE FIGURAS}

Figura 3.1 - Produção Mundial de Cana-De-Açúcar (Em Milhões de Toneladas) (VIEIRA, 2007) .6

Figura 3.2 - Setor Sucroenergético - Mapa de Produção.........................................................6

Figura 3.3 - Comparação Evolutiva da Produção de Álcool e Vinhaça entre 1967 e 2003 ....14

Figura 4.1 - Jar Test utilizado para a aplicação do biopolímero experimental na vinhaça......23

Figura 4.2 - Clareamento da vinhaça após 1h de sedimentação utilizando o biopolímero

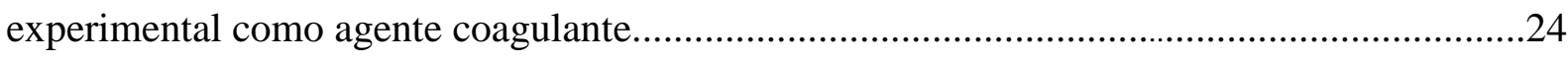

Figura 4.3 - Estrutura do polieletrólito formado durante o processo de floculação..................35

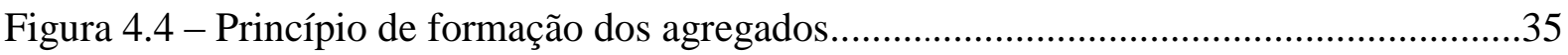

Figura 4.5 - a) Reator Anaeróbio Híbrido de Biomassa e Imobilizada (RAHBI); b) bomba de alimentação de vinhaça; c) frasco de coleta de efluente; d) medidor de gás (frasco de Mariotte).....

Figura 4.6 - Desenho esquemático do reator anaeróbio híbrido de biomassa e imobilizada. a) Esponja de aço inox; b) biomassa imobilizada em material suporte flutuante móvel; c) espaço de biomassa; e d) biomassa (floculenta)

Figura 4.7 - Material utilizado como meio suporte para a biomassa contida nos reatores.......28

Figura 4.8 - Lodo granular utilizado com inóculo. 31

Figura 4.9 - Frasco de Mariotte utilizado no experimento.

Figura 5.1 - Vinhaça antes (a) e após (b) tratamento físico-químico.

Figura 5.2 - Efeito da correção do pH na vinhaça coagulada. a) pH não corrigido (próximo de 12); b) $\mathrm{pH}$ corrigido (próximo de 7).

Figura 5.3 - Variação da COV e eficiência de remoção de DQO na fase de adaptação no reator 1 .

Figura 5.4 - Variação da COV e eficiência de remoção de DQO na fase de adaptação no reator 2

Figura 5.5 - Variação da carga orgânica volumétrica (COV) e eficiência do reator 1 durante a Fase I

Figura 5.6 - Variação da DQO afluente e efluente ao reator 1 durante a Fase I, e sua respectiva eficiência de remoção de DQO. 
Figura 5.8 - Variação da alcalinidade total do afluente e do efluente do reator 1 durante a Fase I....... .45

Figura 5.9 - Variação da carga orgânica volumétrica (COV) e eficiência do reator 1 durante a Fase I

Figura 5.10 - Variação da DQO afluente e efluente ao reator 2 durante a Fase I, e sua respectiva eficiência de remoção de DQO.............................................................................48

Figura 5.11 - Valores de $\mathrm{pH}$ afluente e efluente ao reator 1 na Fase I....................................48

Figura 5.12 - Variação da alcalinidade total do afluente e do efluente do Reator 1 durante a Fase I.

Figura 5.13 - Variação da carga orgânica volumétrica (COV) e eficiência do reator 1 durante a Fase II. .51

Figura 5.14 - Variação da DQO afluente e efluente ao reator 1 durante a Fase II, e sua respectiva eficiência de remoção de DQO..............................................................................52

Figura 5.15 - Valores de $\mathrm{pH}$ afluente e efluente ao reator 1 na Fase II...................................53

Figura 5.16 - Variação da alcalinidade total do afluente e do efluente do reator 1 durante a Fase II.

Figura 5.17 - Variação da carga orgânica volumétrica (COV) e eficiência do reator 2 durante a Fase II. .54

Figura 5.18 - Variação da DQO afluente e efluente ao reator 2 durante a Fase II, e sua respectiva eficiência de remoção de DQO... .55

Figura 5.19 - Valores de pH afluente e efluente ao reator 2 na Fase II. .56

Figura 5.20 - Variação da alcalinidade total do afluente e do efluente do reator 2 durante a Fase II.

Figura 5.21 - Produção de metano, em 1/h, em relação à COV aplicada ao reator 1 durante das Fases I e II. .58

Figura 5.22 - Produção de metano, em 1/h, em relação à COV aplicada ao reator 2 durante das Fases I e II. .58

Figura 5.23 - Produção de $\mathrm{CH}_{4}$ relacionada à DQO removida para os reatores 1 (a) e 2 (b), durante as Fases I e II. .59

Figura 5.24 - Gráfico Box-plot de distribuição de resultados de eficiência de remoção de DQO dos reatores 1 e 2, para a Fase I.

Figura 5.25 - Gráfico de Box-plot de distribuição dos resultados da eficiência de remoção de DQO dos reatores 1 e 2, para a Fase II. .61 
Figura 5.26 - Micrografia eletrônica de varredura de grânulo de reator UASB; Inóculo.

Figura 5.27 - Micrografia Eletrônica de Varredura de grânulo de reator UASB; Reator 1

Figura 5.28 - Micrografia Eletrônica de Varredura de grânulo de reator UASB; Reator 2.

Figura 5.29 - Distribuição percentual dos elementos analisados em EDS nas amostras de lodo granular do inóculo e reatores 1 e 2 .

Figura 5.30 - Micrografia Eletrônica de Varredura da superfície de uma grânulo retirado do reator 1

Figura 5.31 - Micrografia Eletrônica de Varredura da superfície de um grânulo retirado do reator 2 .

Figura 5.32 - Dendrograma relativo aos perfis de bandas do Domínio Archaea e os respectivos índices de similaridade em porcentagem (índice de similaridade de Jaccard)......67 Figura 5.33 - Dendrograma relativo aos perfis de bandas do Domínio Bacteria e os respectivos índices de similaridade em porcentagem (índice de similaridade de Jaccard)

Figura 5.34 - Gráfico tipo Box-plot dos dados obtidos no teste de resistência ao cisalhamento dos grânulos do Inóculo. .70

Figura 5.35 - Imagens utilizadas para medição das áreas médias dos grânulos do inóculo.....71 Figura 5.36 - Gráfico tipo Box-plot dos dados obtidos no teste de resistência ao cisalhamento dos grânulos do reator 1 . .72

Figura 5.37 - Imagens utilizadas para medição das áreas médias dos grânulos do reator $1 . . .72$ Figura 5.38 - Gráfico tipo Box-plot dos dados obtidos no teste de resistência ao cisalhamento dos grânulos do reator 2 .

Figura 5.39 - Imagens utilizadas para medição das áreas médias dos grânulos do reator 2....74 


\section{LISTA DE TABELAS}

Tabela 3.1 - Composição da vinhaça de cana-de-açúcar segundo vários autores 12

Tabela 3.2 - Dados obtidos na aplicação de diferentes coagulantes à vinhaça. .17

Tabela 4.1 - Valores de entrada monitorados nos sistemas de processamento

Tabela 4.2 - Caracterização dos lotes de vinhaça utilizada no experimento .29

Tabela 5.1 - Análises físico-químicas da vinhaça bruta e coagulada. .38

Tabela 5.2 - Características das fases do experimento e as condições adotadas. 40

Tabela 5.3 - Resultados das análises dos parâmetros de monitoramento dos efluentes dos Reatores 1 e 2 . .40

Tabela 5.4 - Concentrações de DQO, COV e íon sulfato do afluente e do efluente e eficiência de remoção de DQO para o reator 1 na Fase I.

Tabela 5.5 - Concentrações de DQO, COV e íon sulfato do afluente e do efluente e eficiência de remoção de DQO para o reator 2 na Fase I.

Tabela 5.6 - Concentrações de DQO, COV e íon sulfato do afluente e do efluente e eficiência de remoção de DQO para o reator 1 na Fase II

Tabela 5.7 - Concentrações de DQO, COV e íon sulfato do afluente e do efluente e eficiência de remoção de DQO para o reator 2 na Fase II

Tabela 5.8 - Análise de EDS para os grânulos do inóculo e reatores 1 e 2.

Tabela 5.9 - Valores médios do diâmetro dos grânulos antes e após o teste de resistência mecânica.

Tabela 5.10 - Dados estatísticos descritivos obtidos no cálculo das áreas médias dos grânulos, $\mathrm{em} \mathrm{mm}^{2}$ 


\section{LISTA DE ABREVIATURAS E SIGLAS}

AME - Atividade Metanogênica Específica

CETESB - Companhia Ambiental do Estado de São Paulo

CONAB - Companhia Nacional de Abastecimento

CONAMA - Conselho Nacional do Meio Ambiente

COT - Carbono Orgânico Total

COV - Carga Orgânica Volumétrica

DBO - Demanda Bioquímica de Oxigênio

DGGE - Eletroforese em Gel de Gradiente Desnaturante

DQO - Demanda Química de Oxigênio

EDS - Espectrometria de Energia Dispersiva de Raios-X

ETE - Estação de Tratamento de Esgotos

MEV - Microscopia Eletrônica de Varredura

NTK - Nitrogênio Total Kjealdahl

PCR - Reação em Cadeia da Polimerase

pH - Potencial Hidrogeniônico

$\mathrm{R} 1$ - Reator 1

R2 - Reator 2

RAHBI - Reator Anaeróbio Híbrido de Biomassa Imobilizada

SSF - Sólidos Suspensos Fixos

SST - Sólidos Suspensos Totais

SSV - Sólidos Suspensos Voláteis 
viii

ST - Sólidos Totais

STD - Sólidos Totais Dissolvidos

STF - Sólidos Totais Fixos

SVT - Sólidos Voláteis Totais

UASB - Upflow Anaerobic Sludge Blanket

UDOP - União dos Produtores de Bioenergia

UNICA - União da Indústria da Cana-de-Açúcar 


\section{SUMÁRIO}

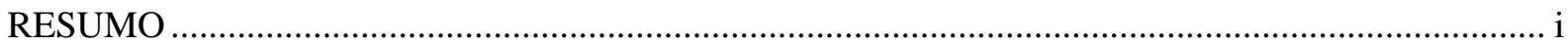

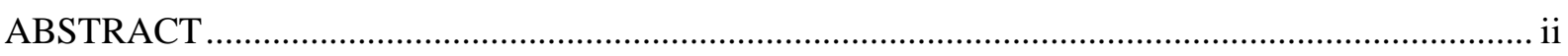

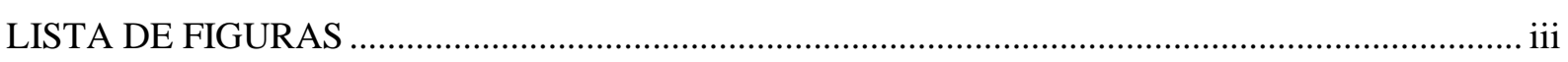

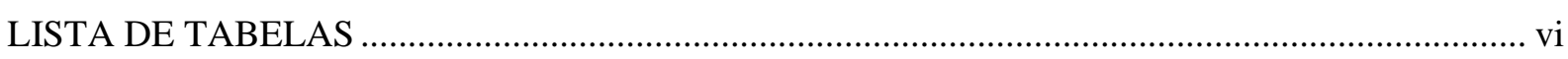

LISTA DE ABREVIATURAS E SIGLAS _............................................................................... vii

1. INTRODUÇÃ

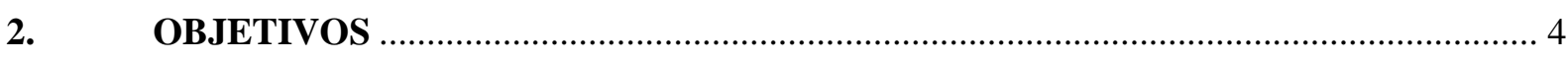

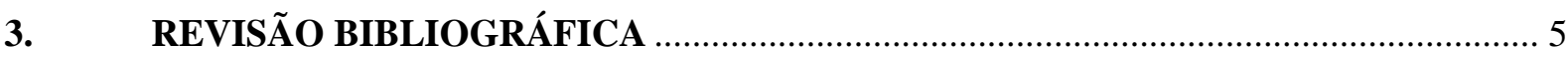

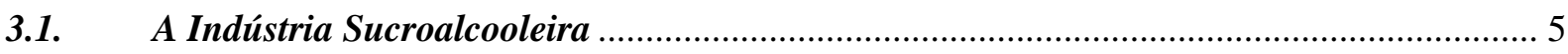

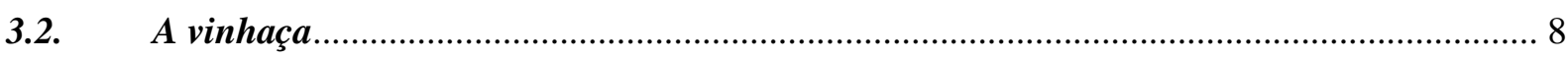

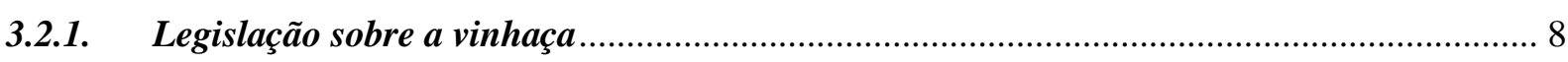

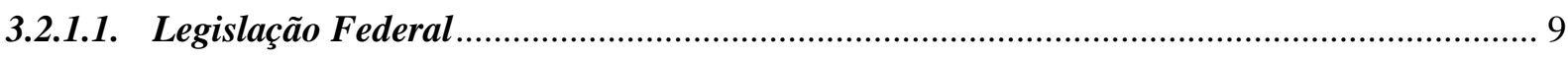

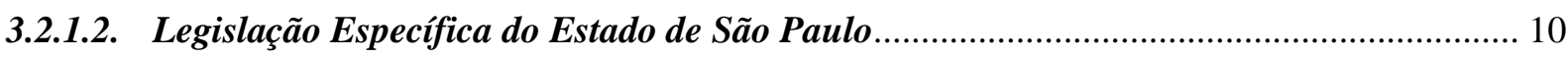

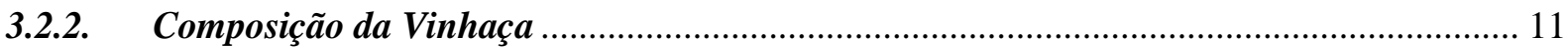

3.2.3. Disposição da Vinhaça - Fertirrigação e seus Impactos Ambientais ................................ 13

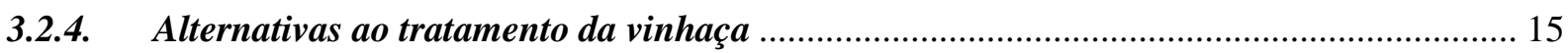

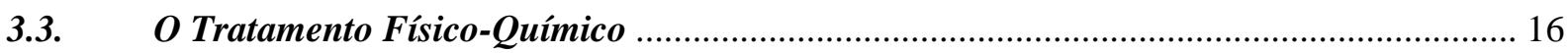

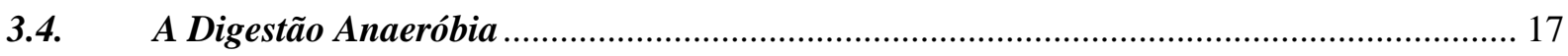

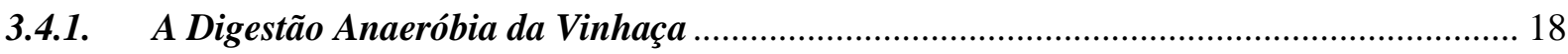

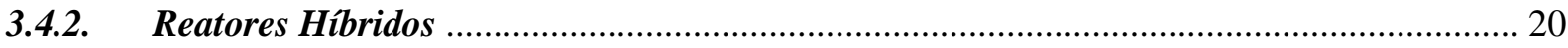

3.4.3. Potencias Inibidores da Biodigestão Anaeróbia da Vinhaça ............................................. 21

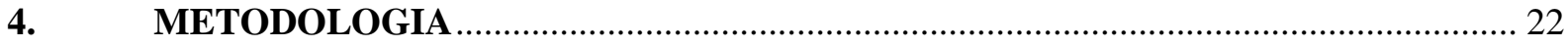

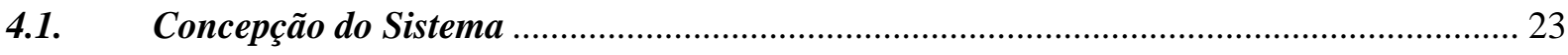

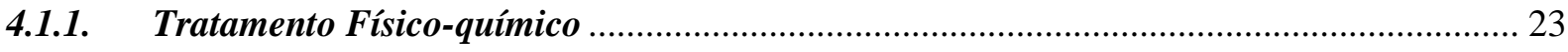

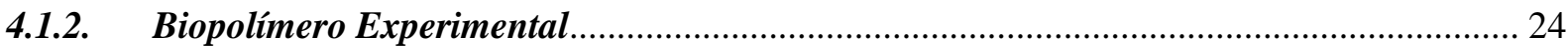

4.1.3. Reator Anaeróbio Híbrido em Escala de Bancada ……................................................... 26

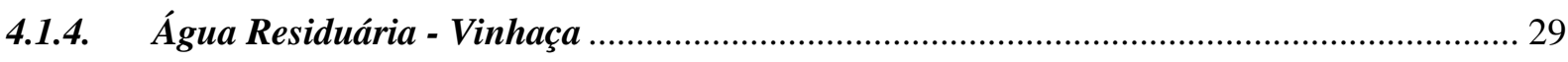

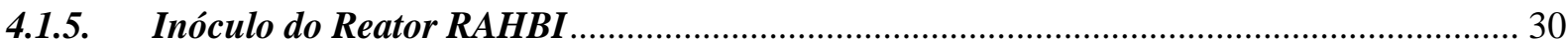

4.2. Análises de Monitoramento e Caracterização ……............................................................ 32

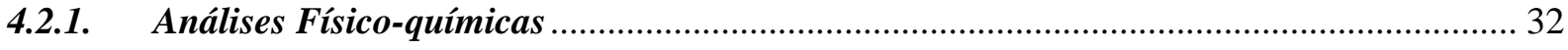

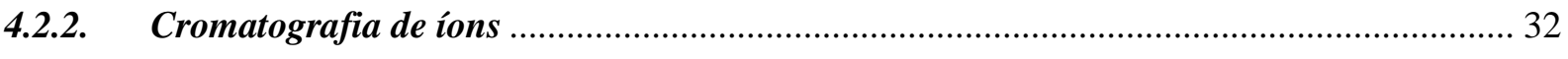

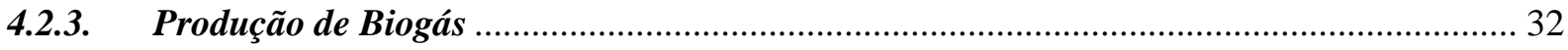




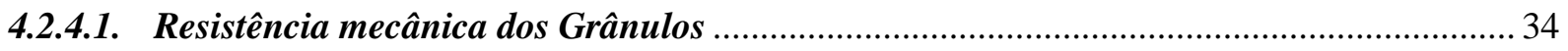

4.2.4.2. Análise estatística dos grânulos submetidos ao teste de resistência mecânica ...................35

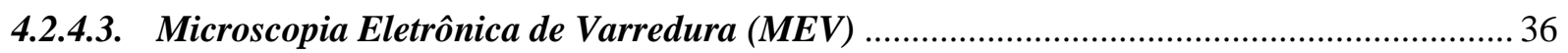

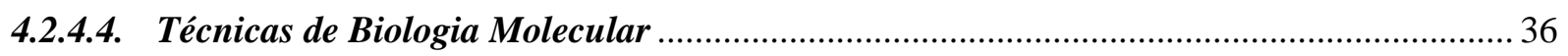

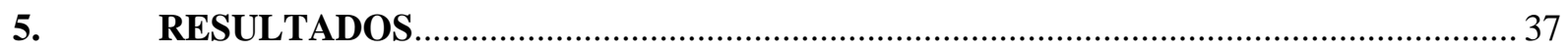

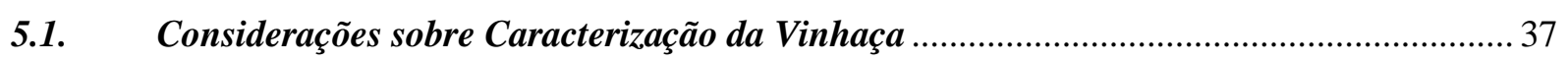

5.2. Tratamento Físico-Químico - Processo de Coagulação da Vinhaça.................................. 38

5.3. Fases do processamento Anaeróbio da Vinhaça .........................................................40

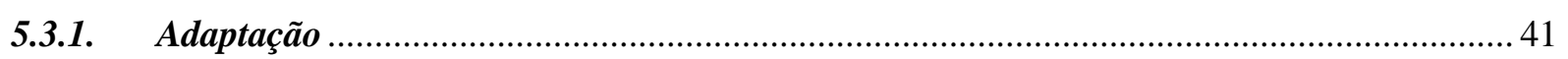

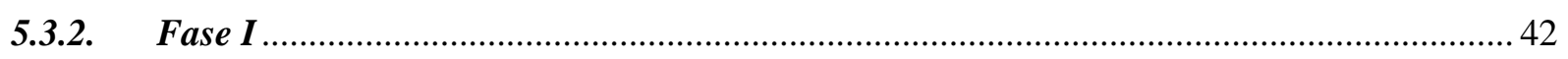

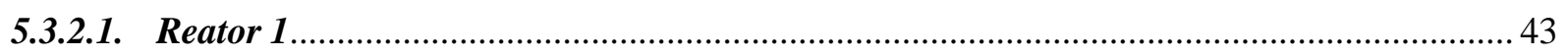

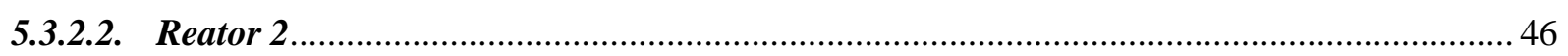

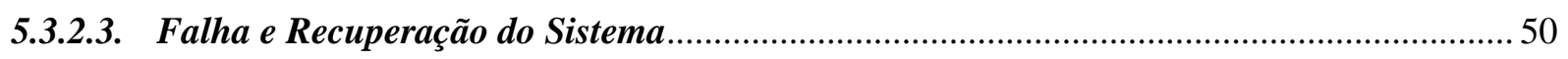

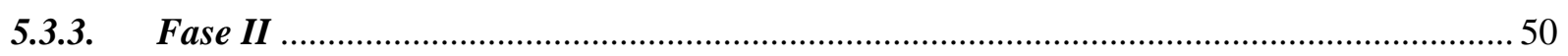

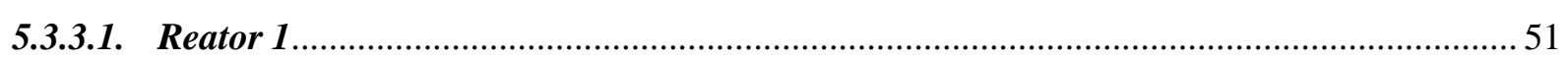

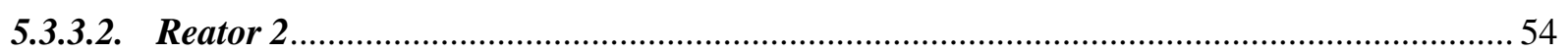

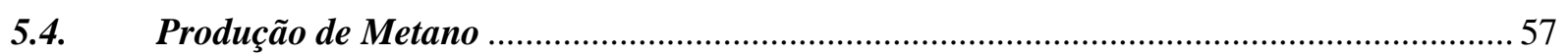

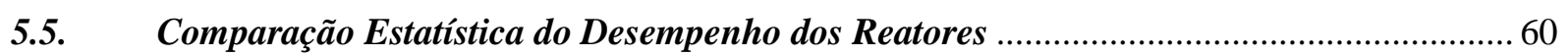

5.6. $\quad$ Análises do Lodo Granular presente no Inóculo, reator 1 e reator 2 ...............................62

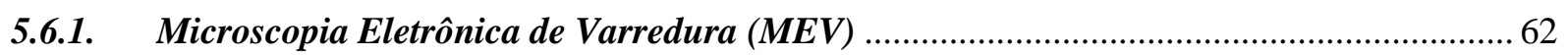

5.6.2. Análise Qualitativa da Comunidade Microbiana presente no Inóculo, reator 1 e reator 267

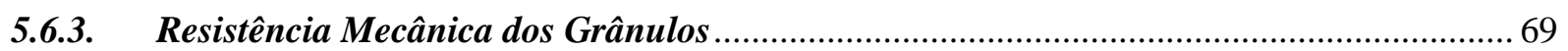

5.6.3.1. Análise estatística dos dados obtidos no teste de resistência mecânica dos grânulos......... 70

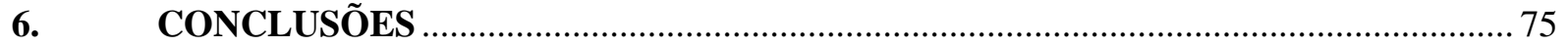

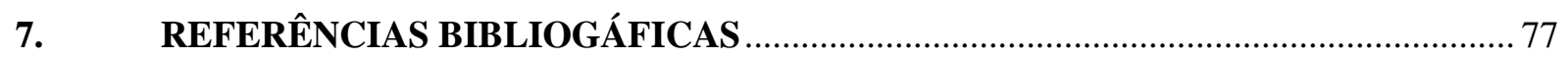

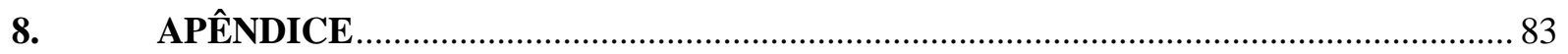

8.1. Comparativo entre as eficiências de remoção de DQO dos reatores 1 e 2 (Item 5.5) ........83

8.2. Comparativo entre as áreas dos grânulos do inóculo no teste de resistência mecânica ao cisalhamento (item 5.6.3.1)

8.3. Comparativo entre as áreas dos grânulos do reator 1 no teste de resistência mecânica ao cisalhamento (item 5.6.3.1)

8.4. Comparativo entre as áreas dos grânulos do reator 2 no teste de resistência mecânica ao cisalhamento (item 5.6.3.1) 


\section{INTRODUÇÃO}

Segundo a União da Indústria da Cana-de-Açúcar (UNICA), a produção de álcool para a safra de 2011/2012 foi de 20,38 bilhões de litros. A vinhaça, subproduto do processo de fermentação do caldo da cana-de-açúcar para a fabricação de álcool, é produzida na proporção de 14:1 em relação ao álcool, ou seja, para cada litro de álcool, aproximadamente 14 litros de vinhaça são produzidos. Isto equivale a 285,32 bilhões de litros desta água residuária no Brasil em apenas uma safra (UNICA, 2012; VIANA, 2006).

A vinhaça é uma água residuária muito concentrada, podendo atingir concentrações acima de $100 \mathrm{~g} / \mathrm{L}$ de DQO (matéria orgânica), valor que é 200 vezes acima do normalmente encontrado em esgotos domésticos, e sendo produzida à temperatura em torno de 80 e $90^{\circ} \mathrm{C}$. Para evitar maiores danos ambientais é despejada, após resfriamento, in natura no solo como fertilizante, sem qualquer tratamento (VIANA, 2006).

Mesmo com os efeitos benéficos da vinhaça no solo (CAMBIUM, 1983), CENTURÍON et al. (1989) alertam sobre a aplicação excessiva da vinhaça no solo. Esta forma de aplicação conduz a efeitos indesejáveis, como a queda da qualidade da cana para produção de açúcar, contaminação do lençol freático e até a salinização do solo.

Com o objetivo de reduzir o potencial poluidor da aplicação de vinhaça diretamente ao solo, faz-se necessário pensar em algum tipo de tratamento prévio da vinhaça, visando reduzir, principalmente, a elevada carga orgânica presente na vinhaça.

Estudos sobre o processo de coagulação e floculação da vinhaça ainda são incipientes no mundo. Em um trabalho publicado por GONÇALVES e SILVA (2000), foram estudados os efeitos dos coagulantes óxido de cálcio e sulfato ferroso na vinhaça. Como resultado deste trabalho, verificou-se que há maior remoção de DQO quando o pH desta água residuárias é próximo a 12,4.

A presença de metais em coagulantes utilizados para o tratamento de água e águas residuárias pode ocasionar danos indesejáveis ao organismo humano, principalmente o sistema nervoso. Este fato cientificamente comprovado é alvo de frequentes pesquisas médicas no mundo inteiro, exigindo controle rígido sobre a presença dos metais tanto na água potável quanto nos mananciais.

Uma alternativa para os tratamentos que necessitam da utilização de coagulantes metálicos são os de origem natural. Estes tipos de coagulantes apresentam vantagens em 
relação aos químicos por serem biodegradáveis e não tóxicos. Outra característica destes coagulantes é a menor geração de lodo e menores teores de metais (KAWAMURA, $1991^{1}$ apud BONGIOVANI et al., 2010)

Outra forma de redução do conteúdo orgânico da vinhaça é o tratamento biológico que, em geral, possui baixos custos de implantação e operação, sendo uma forma alternativa e eficaz para o tratamento. O sistema deve ser robusto, tendo capacidade de assimilar grandes variações de vazão e carga. O processo de tratamento anaeróbio é interessante no ponto de vista econômico, pois requer menor consumo energético frente ao tratamento aeróbio.

Dentre os reatores anaeróbios, o UASB (Upflow Anaerobic Sludge Blanket), reator anaeróbio de fluxo ascendente e manta de lodo se enquadra nessa necessidade. O UASB é um reator de alta taxa de grande potencial de carga, sendo possível aplicação de até $30 \mathrm{~kg} / \mathrm{m}^{3}$ dia de DQO. Sua característica principal é a presença de um separador interno trifásico, que permite a separação das fases líquida/sólida/gasosa da água residuária, otimizando seu tratamento.

A evolução da tecnologia no desenvolvimento de reatores anaeróbios impulsionou a pesquisa de configurações que permitissem alcançar alta eficiência na remoção da matéria orgânica em tanques de dimensões cada vez menores e em curtos períodos de tempo. O reator anaeróbio híbrido, o qual possui uma manta de lodo na parte inferior e recheio na parte superior, foi desenvolvido por MAXHAM e WAKAMIYA (1981).

DEFOUR et al. (1994) discorre sobre diferentes sistemas de acumulação de biomassa em reator com tecnologia anaeróbia e acrescentaram que o reator híbrido é apropriado para efluentes complexos ou muito concentrados, como a vinhaça.

Entretanto, o tratamento anaeróbio de águas residuárias apresenta alguns problemas, principalmente no que tange aos distúrbios causados no ciclo natural do enxofre, presente em altas concentrações na vinhaça. Este comportamento leva a desequilíbrios locais, tanto nesse ciclo, como também nos ciclos de matéria orgânica, nitrogênio e metais. (LENS et al., 2002).

Muitos são os efeitos adversos da poluição por compostos de enxofre. Isso inclui poluição de compartimentos ambientais como a água (e.g., acidificação, lixiviação de metais tóxicos, produção potencial de sulfetos tóxicos e corrosivos), ar (emissão de $\mathrm{SO}_{2}, \mathrm{H}_{2} \mathrm{~S}$ e compostos de enxofre voláteis odorantes) e sedimentos (liberação de metais pesados em sedimentos dragados expostos ao oxigênio) (SUBTIL, 2007).

\footnotetext{
${ }^{1}$ KAWAMURA, S. Effectiveness of natural polyelectrolytes in water treatment. Journal American Water Works Association, v. 83, n. 10, p. 88-91, 1991.
} 
O processamento da vinhaça na sequência coagulação/floculação, visando à separação líquido-sólido, complementado pela digestão anaeróbia das fases líquida e sólida, em princípio, possibilita um tratamento mais eficiente e simplificado, tanto para a remoção de carga orgânica quanto para a produção de metano. As vantagens técnicas concebidas teriam como base a diminuição da carga aplicada ao tratamento da fase líquida, permitindo um menor tempo de detenção e o fornecimento de um lodo concentrado, que apesar de exigir um tempo de detenção elevado, possui um volume pequeno. Em conjunto a isso, o efluente final apresentaria uma qualidade para fins de fertirrigação melhorada. Esta hipótese foi testada neste estudo, aplicando-se um biopolímero à base de cálcio para a coagulação/floculação. Nesta etapa da pesquisa foram avaliados os efeitos do uso do biopolímero no rendimento do reator anaeróbio no processamento da vinhaça. 


\section{OBJETIVOS}

O objetivo geral dessa pesquisa foi comparar o desempenho de dois reatores anaeróbios híbridos de biomassa e imobilizada (RAHBI) de fluxo ascendente contínuo, em escala de laboratório, no processamento da vinhaça de cana-de-açúcar. Um dos reatores recebeu vinhaça sem tratamento prévio (vinhaça pura) e outro vinhaça previamente submetida a tratamento físico-químico (coagulação), com adição de um biopolímero experimental à base de cálcio.

Para isso foram fixados os seguintes objetivos específicos:

a. Avaliar o desempenho, em termos de eficiência de remoção de DQO, sulfato e produção de $\mathrm{CH}_{4}$, dos reatores RAHBI quando submetido ao aumento gradual de carregamento orgânico;

b. Verificar a eficácia do uso da coagulação, utilizando o biopolímero como coagulante, anteriormente à digestão anaeróbia da vinhaça;

c. Avaliar os efeitos da aplicação da vinhaça, com e sem pré-tratamento, na biomassa contida em cada reator, comparando com os grânulos do inóculo. 


\section{REVISÃO BIBLIOGRÁFICA}

\subsection{A Indústria Sucroalcooleira}

Em 1975, o governo brasileiro criou o Programa Nacional do Álcool (Proálcool), que diversificou a atuação da indústria açucareira com grandes investimentos apoiados pelo Banco Mundial, possibilitando a ampliação da área plantada com cana-de-açúcar e a implantação de destilarias de etanol. A experiência serviu como alternativa para diminuir a vulnerabilidade energética do País, devido à crise mundial do petróleo.

O desenvolvimento da engenharia nacional, após o segundo choque do petróleo, em 1979, permitiu o surgimento de motores especialmente desenvolvidos para funcionar com etanol hidratado. Em 1984, os carros a etanol passaram a responder por 94,4\% da produção das montadoras instaladas no Brasil. Desde 1986, a redução do impacto da crise do petróleo e os planos econômicos internos para combater a inflação estimularam uma curva descendente na produção de carros a etanol, que culminou com a crise de abastecimento de 1989. Com isso, a participação anual dos veículos a etanol caiu para 1,02\% na frota nacional, em 2001.

A queda da demanda do etanol hidratado foi compensada pelo maior uso do etanol anidro (sem água) misturado à gasolina, o que acompanhou o crescimento da frota brasileira de veículos leves. Em março de 2003, foi lançado o carro Flex-Fuel, movido a etanol, gasolina ou com qualquer mistura entre os dois, iniciando uma nova onda de crescimento do setor. Além disso, o aumento da preocupação com a disponibilidade e preço dos combustíveis fósseis e as preocupações com o meio-ambiente e o aquecimento global têm tornado o etanol uma alternativa renovável de combustível para o Brasil e o mundo (UNICA, 2012).

Uma das principais culturas do mundo, a cana-de-açúcar é cultivada em mais de cem países, numa área de cerca de 20,1 milhões de hectares. Apesar dessa distribuição, 75\% da produção está concentrada em oito países, entre os quais o Brasil, que é o maior produtor com $31,2 \%$ do total mundial.

A cana-de-açúcar ocupa cerca de 7 milhões de hectares ou cerca de $2 \%$ de toda a terra arável do País, que é o maior produtor mundial, seguido por Índia, China, Tailândia e Paquistão, conforme demonstrado na Figura 3.1. 


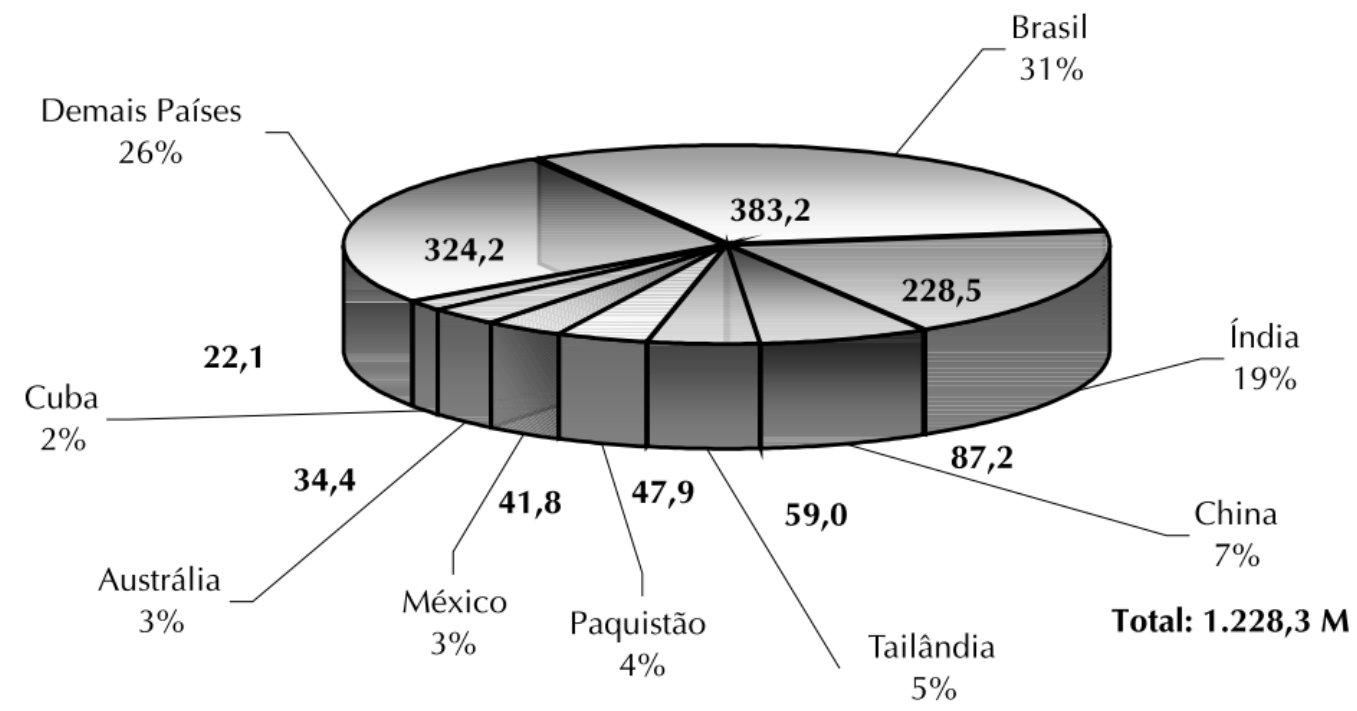

Figura 3.1 - Produção Mundial de Cana-de-Açúcar (em milhões de toneladas) (VIEIRA, 2007).

As regiões de cultivo são Sudeste, Centro-Oeste, Sul e Nordeste, permitindo duas safras por ano (Figura 3.2). Portanto, durante todo o ano o Brasil produz açúcar e etanol para os mercados interno e externo.

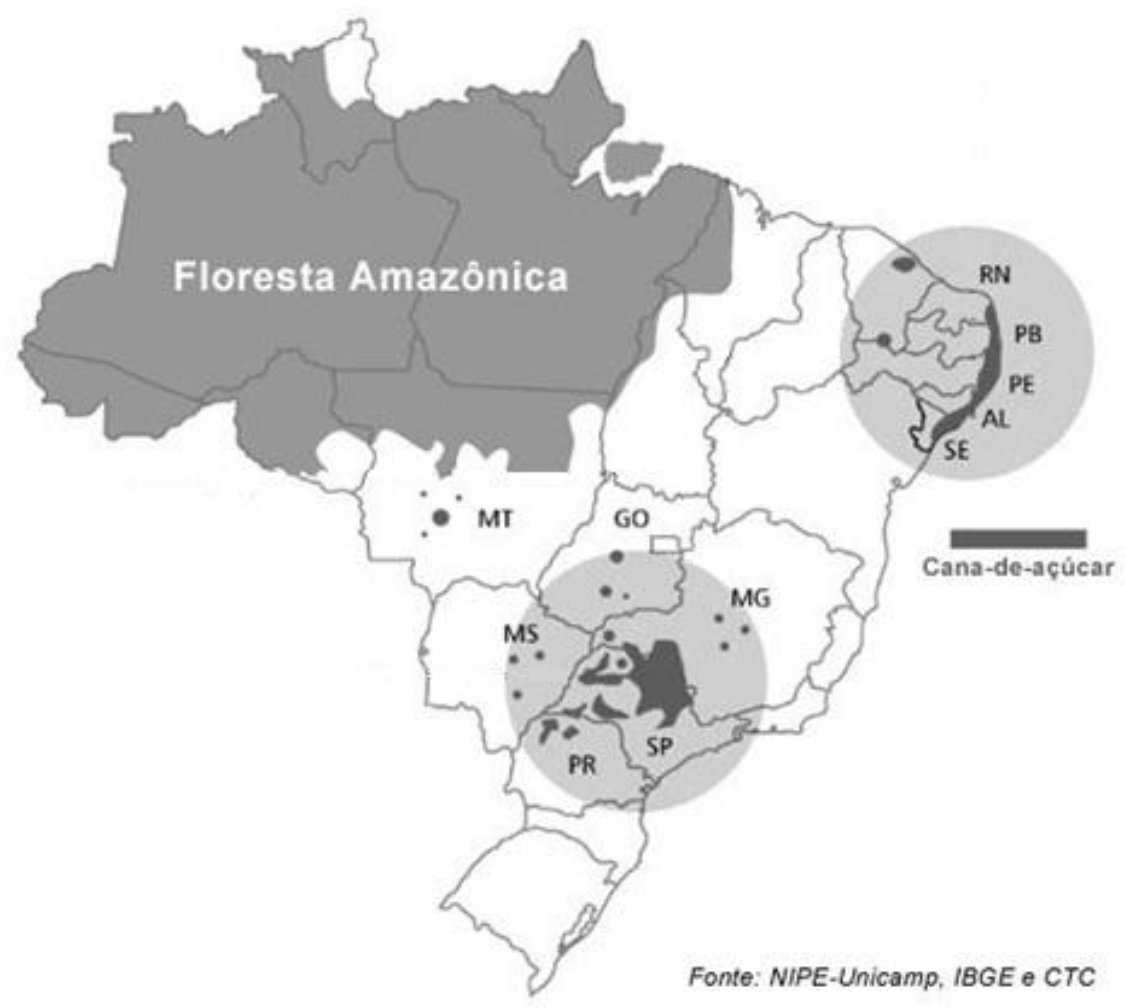

Figura 3.2 - Setor Sucroenergético - Mapa de Produção. 
O setor sucroalcooleiro brasileiro prevê que na safra de 2011/2012 serão moídas um total 588,915 milhões de toneladas de cana-de-açúcar. A previsão de esmagamento de cana para a produção de açúcar é de 288,287 milhões de toneladas, correspondendo a 48,95\% da previsão de moagem de 588,915 mil toneladas. Para a produção de etanol serão esmagadas 300,628 milhões de toneladas de cana-de-açúcar com geração de 23,687 bilhões de litros de etanol (CONAB, 2011) $)^{2}$.

Atualmente o setor conta com 411 usinas registradas na União dos Produtores de Bioenergia (UDOP), sendo 161 localizadas do estado de São Paulo. (UDOP, 2012); (SMA, 2012). As exportações da cadeia produtiva da cana somaram US\$ 9,29 bilhões, em 2010, representando $67 \%$ das exportações brasileiras desse segmento. $\mathrm{O}$ principal produto foi o açúcar, com US\$ 8,62 bilhões (IVESTE SP, 2011).

A área cultivada com cana-de-açúcar na safra de 2011/2012 que será colhida e destinada à atividade sucroalcooleira está estimada em 8.434,3 mil hectares, distribuídos em todos estados produtores. O Estado de São Paulo continua sendo o maior produtor com 52,6\% (4.436,53 mil hectares), seguido por Minas Gerais com 9,00\% (759,21 mil hectares), Goiás com 7,97\% (672,43 mil hectares), Paraná com 7,26\% (612,25 mil hectares), Mato Grosso do Sul com 5,70\% (480,86 mil hectares), Alagoas com 5,39\% (454,54 mil hectares), e Pernambuco com 3,85\% (324,73 mil hectares). Nos demais estados produtores as áreas são menores, mas, com bons índices de produtividade (CONAB, 2011).

A cana-de-açúcar no Brasil praticamente não é irrigada. As necessidades hídricas, na fase agrícola, são sanadas naturalmente pelo regime de chuvas das regiões produtoras, principalmente no Centro-sul do país, e complementadas pela aplicação da vinhaça (subproduto da produção do etanol que é rica em água e nutrientes orgânicos) em processo chamado de fertirrigação. Os níveis de captação e lançamento de água para uso industrial têm sido reduzidos substancialmente nos últimos anos, de cerca de 5 metros cúbicos por tonelada para cerca de 1 metro cúbico por tonelada processada. (UNICA, 2012).

\footnotetext{
${ }^{2}$ Dados obtidos no ano de 2011.
} 


\subsection{A vinhaça}

Durante o processo de produção do etanol, é gerada vinhaça em elevada quantidade e sua produção varia em função dos diferentes processos, como fermentação do mosto ${ }^{3}$ e destilação do vinho. Para se produzir um litro de etanol, é gerado em torno de 10 a 18 litros de vinhaça, dependendo das condições operacionais e das instalações utilizadas (UNICA, 2012).

Trata-se de um efluente com 2 a $6 \%$ de constituintes sólidos, onde se destaca a matéria orgânica, em maior quantidade. Em termos minerais apresenta quantidade apreciável de potássio e quantidade média de cálcio e magnésio.

Dos resíduos da fabricação do álcool, a vinhaça é o mais importante, não só em termos de volume gerado, mas também em potencial poluidor, que se adiciona à dificuldade para a sua eliminação.

Segundo WILKIE, RIEDESEL e OWENS (2000) considera-se que a destilação eficiente na produção de etanol, a partir da cana-de-açúcar, deixa um residual de 0,1 a $0,2 \%$ de etanol no despejo. Estima-se que cada $1 \%$ de glicose efluente na vinhaça pode equivaler a $16 \mathrm{~g}$ de $\mathrm{DQO} / 1$ e que, $0,1 \%$ de etanol residual na vinhaça representa um incremento de $2,0 \mathrm{~g}$ de DQO/l no efluente.

A vinhaça apresenta ainda, problemas de insalubridade, tem mau cheiro, devido à formação de gases decorrentes da decomposição anaeróbia, podendo transferir para água (corpo receptor) características de toxicidade, turbidez e cor (CRUZ, 1991).

\subsubsection{Legislação sobre a vinhaça}

Devido à grande produção deste efluente, desde 1965 houve preocupação em criar um código jurídico que restringisse o descarte sem controle de vinhaça. Com o passar dos anos, os códigos evoluíram de forma a ser possível tornar a reutilização da vinhaça cada vez mais controlada (SOUZA, 2010). Apresentam-se, nos próximos dois itens, um breve resumo

\footnotetext{
${ }^{3}$ Todos os líquidos susceptíveis à fermentação são denominados mostos; daí tem-se o mosto de cana. Uma vez fermentado, o mosto passa a chamar-se vinho, que pode ser destilado possibilitando a recuperação do álcool produzido na fermentação, restando o resíduo que é a vinhaça (VIANA, 2006).
} 
com algumas das mais importantes leis criadas tanto pelo governo federal, quanto as específicas para o Estado de São Paulo.

\subsubsection{Legislação Federal}

Algumas leis importantes para a manutenção do meio ambiente vigentes no país mostram, desde a criação do Código Florestal, em 1965, uma crescente preocupação com os impactos causados pela indústria sucroalcooleira (SOUZA, 2010).

A seguir estão citadas algumas destas leis, cujo impacto no setor sucroalcooleiro é importante.

- Lei $\mathrm{n}^{\circ} 4.771$, de 15 de setembro de 1965 - código Florestal;

- Portaria MINISTÉRIO n 323, de 29/11/1978 - proíbe o lançamento da vinhaça nos mananciais superficiais;

- Portaria do Ministério do Interior $n^{\circ} 158$, de 03 de novembro de 1980 - dispõe sobre o lançamento de vinhoto em coleções hídricas e sobre efluentes de destilarias e usinas de açúcar;

- Portaria do Ministério do Interior n ${ }^{\circ} 124$, de 20 de agosto de 1980 - normas para localização e construção de instalações que armazenem substâncias que possam causar poluição hídrica;

- Resolução Conselho Nacional do Meio Ambiente - CONAMA - n0002, de 05/06/1984 - determinação da realização de estudos e apresentação de projeto de resolução contendo normas para controle da poluição causada pelos efluentes das destilarias de álcool e pelas águas de lavagem da cana;

- Resolução Conselho Nacional do Meio Ambiente - CONAMA - n0001, de 23/01/1986 - obrigatoriedade da Avaliação de Impacto Ambiental (AIA) e do Relatório de Impacto Ambiental (RIMA) para novas indústrias instaladas ou qualquer ampliação efetuada nas existentes;

- Resolução do CNRH no 15 , de 01 de junho de 2001 - diretrizes para a gestão integrada das águas superficiais, subterrâneas e de chuvas. 


\subsubsection{2. $\quad$ Legislação Específica do Estado de São Paulo}

Algumas das mais importantes leis focadas na manutenção do meio ambiente específicas do Estado de São Paulo são listadas com o objetivo de mostrar que a preocupação nesse Estado foi maior, principalmente, por conter mais de $60 \%$ da produção de cana-deaçúcar (SOUZA, 2010).

- Lei $\mathrm{n}^{\circ}$ 997, de 31 de maio de 1976 - dispõe sobre o controle da poluição do meio ambiente;

- Decreto $n^{\circ} 8.468$, de 08 de setembro de 1976 - aprova o regulamento da Lei $n^{\circ} 997$ de31 de maio de 1976 - Controle da poluição das águas, ar, resíduos, padrões, exigências, licenciamento, penalidades;

- Lei $\mathrm{n}^{\circ}$ 6.134, de 02/06/1988, art. 5, do Estado de São Paulo. - “Os resíduos líquidos, sólidos ou gasosos, provenientes de atividades agropecuárias, industriais, comerciais ou de qualquer outra natureza, só poderão ser conduzidos ou lançados de forma a não poluírem as águas subterrâneas";

- Lei $\mathrm{n}^{\mathrm{o}}$ 6.171, de 04 de julho de 1988 - dispõe sobre o uso, conservação e preservação do solo agrícola;

É importante citar a norma técnica P4.231 da Companhia Ambiental do Estado de São Paulo (CETESB), versão de Dezembro de 2006, que estabelece os critérios e procedimentos para o armazenamento, transporte e aplicação da vinhaça. Esta norma pode ser consultada na página da web da CETESB ( $\underline{\text { www.cetesb.sp.gov.br }}$ )

Tendo em vista tais legislações sobre a preservação do meio ambiente e o controle do lançamento da vinhaça, justificam-se várias pesquisas nacionais na área, como:

- o impacto da disposição da vinhaça nas propriedades do solo e do lençol freático (SILVA, GRIEBELER e BORGES, 2007) e (LYRA, ROLIM e SILVA, 2003);

- o processamento biológico da vinhaça (RIBAS, 2006), (VIANA, 2006), (CAMILO et al., 2007), (CABELLO, SCOGNAMIGLIO e TERÁN, 2009), (MACHADO e FREIRE, 2009), (BROWN et al., 2011), dentre outros.

- o tratamento físico-químico da vinhaça (GONÇALVES e SILVA, 2000), (RAPHAEL et al., 2009), (SANTIAGO, GIRARDI e GIMENES, 2009) dentre outros. 


\subsubsection{Composição da Vinhaça}

A composição da vinhaça pode variar, dependendo das características e qualidade do vinho submetido à destilação. Também depende da composição da matéria prima, do preparo do mosto, do método de fermentação adotado e do modo de conduzir a fermentação alcoólica.

Além disso, deve-se considerar a linhagem de levedura utilizada, o tipo de aparelho destilador, a forma de destilação, a localização da destilaria e a época de amostragem (SILVA e ORLANDO FILHO, 1981).

De acordo com o tipo de mosto, a vinhaça pode resultar de três origens distintas: (i) vinhaça de mosto de melaço - o mosto é produzido a partir de um subproduto da produção de açúcar, chamado melaço; (ii) vinhaça de mosto de caldo - produzida em destilarias que produzem apenas álcool - é produzida a partir da fermentação alcoólica do caldo e (iii) vinhaça de mosto misto - o mosto é produzido com mistura de caldo e melaço. Em uma única safra, a vinhaça pode se apresentar nas diversas categorias, resultantes do uso de caldo, melaço ou com mistura de caldo mais melaço (SANTOS, 2000).

O constituinte principal da vinhaça é a matéria orgânica, basicamente sob a forma de ácidos orgânicos e, em menor quantidade, por cátions como o K, Ca e Mg. Dos efluentes líquidos da indústria sucroalcooleira, a vinhaça é a que possui maior carga poluidora. A temperatura da vinhaça que sai dos aparelhos de destilação é de 85 a $90{ }^{\circ} \mathrm{C}$ (ROSSETTO, 1987). Em termos de demanda química de oxigênio (DQO), a concentração de matéria orgânica da vinhaça pode atingir valores superiores a cem vezes a DQO do esgoto sanitário, que varia entre 450 e $800 \mathrm{mg} / \mathrm{L}$ (VON SPERLING, 2005).

De acordo com a Tabela 3.1, observa-se uma relação média de 46\% de DBO/DQO, ou seja, quase metade de toda a DQO presente na vinhaça, é constituída de matéria orgânica biodegradável. Este é um dado importante, pois indica o potencial poluidor deste resíduo e uma possibilidade de tratamento biológico para a remoção desta parcela, em especial o tratamento anaeróbio. Isto melhoraria a viabilidade da fertirrigação como um pós-tratamento adequado para a manutenção do solo e reposição de macro-nutrientes, ao mesmo tempo em que impede o lançamento direto da vinhaça em corpos hídricos receptores. 
Tabela 3.1 - Composição da vinhaça de cana-de-açúcar segundo vários autores.

\begin{tabular}{|c|c|c|c|c|c|c|c|c|}
\hline Referência & $\begin{array}{c}\text { Tipo de } \\
\text { Mosto de } \\
\text { Vinhaça }\end{array}$ & $\mathrm{pH}$ & $\begin{array}{l}\mathrm{DBO} \\
(\mathrm{g} / \mathrm{l})\end{array}$ & $\begin{array}{c}\text { DQO } \\
(\mathrm{g} / \mathrm{l})\end{array}$ & $\begin{array}{c}\mathrm{N} \\
\text { (total) } \\
(\mathrm{g} / \mathrm{l})\end{array}$ & $\begin{array}{l}\mathrm{SO}_{4} \\
(\mathrm{~g} / \mathrm{l})\end{array}$ & $\begin{array}{c}\mathrm{P}(\text { total }) \\
(\mathrm{g} / \mathrm{l})\end{array}$ & $\begin{array}{c}\mathrm{K}\left(\mathrm{K}_{2-}\right. \\
\left.\mathrm{O}_{5}\right) \\
(\mathrm{g} / \mathrm{l})\end{array}$ \\
\hline $\begin{array}{c}\text { Van Haandel } \\
\text { e Catunda, } \\
\text { (1994) }\end{array}$ & Caldo & 3,5 & 12,0 & 25,0 & 0,40 & 0,20 & 0,80 & - \\
\hline $\begin{array}{c}\text { Driessen et } \\
\text { al. (1994) }\end{array}$ & Caldo & 3,5 & 15,0 & 22,0 & 0,40 & 0,06 & - & 0,40 \\
\hline $\begin{array}{l}\text { Costa et. } \\
\text { al. }(1986)\end{array}$ & Caldo & 4,2 & 16,5 & 33,0 & 0,70 & 0,09 & 1,74 & 0,76 \\
\hline $\begin{array}{c}\text { Callander e } \\
\text { Badford } \\
(1983)\end{array}$ & Caldo & 3,9 & - & 26,0 & 1,19 & 0,32 & 2,10 & 1,47 \\
\hline $\begin{array}{c}\text { Lampoglia e } \\
\text { Rossel } \\
(1997)\end{array}$ & Caldo & 4,1 & 11,0 & 24,0 & 0,45 & 0,65 & 0,11 & 1,65 \\
\hline $\begin{array}{c}\text { Lampoglia e } \\
\text { Rossel } \\
(1997) \\
\end{array}$ & Misto & 4,5 & 19,8 & 45,0 & 0,60 & 3,70 & 0,10 & 4,00 \\
\hline $\begin{array}{c}\text { Costa et al. } \\
(1986)\end{array}$ & Misto & 4,5 & 19,8 & 45,0 & 0,71 & 0,09 & 3,82 & 3,73 \\
\hline $\begin{array}{c}\text { Souza et al. } \\
(1992)\end{array}$ & Misto & 3,9 & - & 31,5 & 0,37 & 0,03 & 1,30 & 0,42 \\
\hline $\begin{array}{c}\text { Costa et al, } \\
(1986)\end{array}$ & Melaço & 4,6 & 25,0 & 65,0 & 1,61 & 0,13 & 6,50 & 6,40 \\
\hline $\begin{array}{c}\text { de Menezes, } \\
(1989)\end{array}$ & Melaço & 4,1 & 25,8 & 48,0 & 0,82 & 0,16 & - & - \\
\hline $\begin{array}{l}\text { Harada et al. } \\
\text { (1996) }\end{array}$ & Melaço & 4,1 & 30,0 & 120 & 1,60 & 0,06 & 1,92 & 4,60 \\
\hline $\begin{array}{c}\text { Sheehan e } \\
\text { Greenfield, } \\
(1980)\end{array}$ & Melaço & 4,2 & 35,7 & 77,7 & 1,78 & 0,17 & 8,90 & 4,36 \\
\hline $\begin{array}{l}\text { Driessen et } \\
\text { al. }(1994)\end{array}$ & Melaço & 3,9 & 39,0 & 100 & 1,03 & 0,03 & 7,00 & 9,5 \\
\hline $\begin{array}{c}\text { Goyal et al, } \\
(1996)\end{array}$ & Melaço & 4,1 & 60,0 & 98,0 & 1,20 & 1,50 & 1,20 & 5,00 \\
\hline $\begin{array}{c}\text { Sanchez } \\
\text { Riera } \\
\text { et al. }(1985)\end{array}$ & Melaço & 4,8 & - & 100 & 2,5 & 0,30 & 1,75 & 0,70 \\
\hline $\begin{array}{l}\text { Casarini et } \\
\text { al. (1987) }\end{array}$ & Melaço & 4,2 & - & 24,6 & 0,81 & 0,03 & 1,98 & 0,61 \\
\hline $\begin{array}{c}\text { Lampoglia e } \\
\text { Rossel, } \\
\text { (1997) }\end{array}$ & Melaço & 4,6 & 25,0 & 65,0 & 1,03 & 6,40 & 0,20 & 5,60 \\
\hline $\begin{array}{c}\text { de Bazua et } \\
\text { al. }(1991)\end{array}$ & Melaço & 5,0 & 27,5 & 64,0 & 1,30 & - & - & 2,80 \\
\hline
\end{tabular}

Fonte: WILKIE, RIEDESEL e OWENS (2000) 


\subsubsection{Disposição da Vinhaça - Fertirrigação e seus Impactos Ambientais}

Até o final da década de 1970, quando a prática foi proibida, grande volumes de vinhaça eram lançados nos mananciais superficiais, principalmente os cursos d'água como rios e ribeirões das proximidades das usinas de açúcar e álcool. Em função do crescimento do setor, a quantidade despejada tendia a aumentar.

Atualmente a disposição da vinhaça no solo é a solução mais empregada pelas usinas, pois seu conteúdo, principalmente potássio, cálcio e magnésio, e também pelo seu elevado teor de matéria orgânica, qualifica este efluente como de alto poder fertilizante. A vinhaça também se apresenta rica em nitrogênio, fósforo e sulfatos, características necessárias à recomposição dos solos agrícolas da agroindústria.

Entretanto, a possibilidade de infiltração e contaminação do lençol freático por meio desta aplicação ficou em evidência, além do comprometimento na qualidade da cana-deaçúcar, em consequência da sua aplicação prolongada no solo, demonstrada em alguns estudos realizados (GONÇALVES e SILVA, 2000; VIANA, 2006).

Com a perspectiva do aumento substancial da produção de vinhaça e tendo em vista o aumento do controle sobre a disposição do resíduo, surgiram diversas iniciativas de busca de tecnologias para solucionar o problema. Neste sentido, observa-se que a política ambiental (neste caso via legislação ambiental) pode ter um papel ativo na seleção de possibilidades tecnológicas (CORAZZA e SALLES-FILHO, 2000).

A composição da vinhaça, rica em minerais e água, e as dificuldades técnicas e econômicas envolvidas em seu tratamento, colaboram para o uso predominante da fertirrigação como um destino final deste efluente. Este é o nome pelo qual ficou conhecida a técnica amplamente adotada pela agroindústria canavieira nacional, notadamente a partir da década de 80 em substituição ao lançamento do resíduo em cursos d'água, que consiste na infiltração da vinhaça in natura no solo, com objetivo de fertilizá-lo e, ao mesmo tempo, de irrigar a cultura da cana-de-açúcar. A fertirrigação é empregada como expediente substituto ao uso da fertilização química, constituindo uma fonte de nutrientes minerais, principalmente de potássio (CORAZZA e SALLES-FILHO, 2000).

As principais razões da ampla difusão (quase a totalidade das indústrias utiliza a vinhaça produzida para fertirrigação) desta prática são (VIANA, 2006):

I. Baixo investimento inicial requerido (tanques de decantação, caminhões, e atualmente bombas e dutos); 
II. Baixo custo de manutenção (pouco pessoal, baixo consumo de óleo diesel e eletricidade gerada localmente);

III. Rápida disposição da vinhaça no solo (sem necessidade de grandes reservatórios reguladores);

IV. Ganhos compatíveis com o investimento (há lucros com a reciclagem do potássio no solo e o retorno do investimento é bastante rápido);

V. Fecha o ciclo interno que envolve a parte agrícola e a industrial no mesmo setor, diminuindo a dependência de insumos externos (fertilizante);

VI. Não envolve uso de tecnologia complexa;

VII. Aumento da produtividade da safra e da produtividade na fabricação do açúcar.

A Figura 3.3 mostra a evolução da produção de vinhaça relacionada à produção de álcool no Brasil desde 1967 a 2003. Foi adotado a proporção álcool:vinhaça de 14:1 e os valores estão expressos em $10^{3} \mathrm{~m}^{3}$.

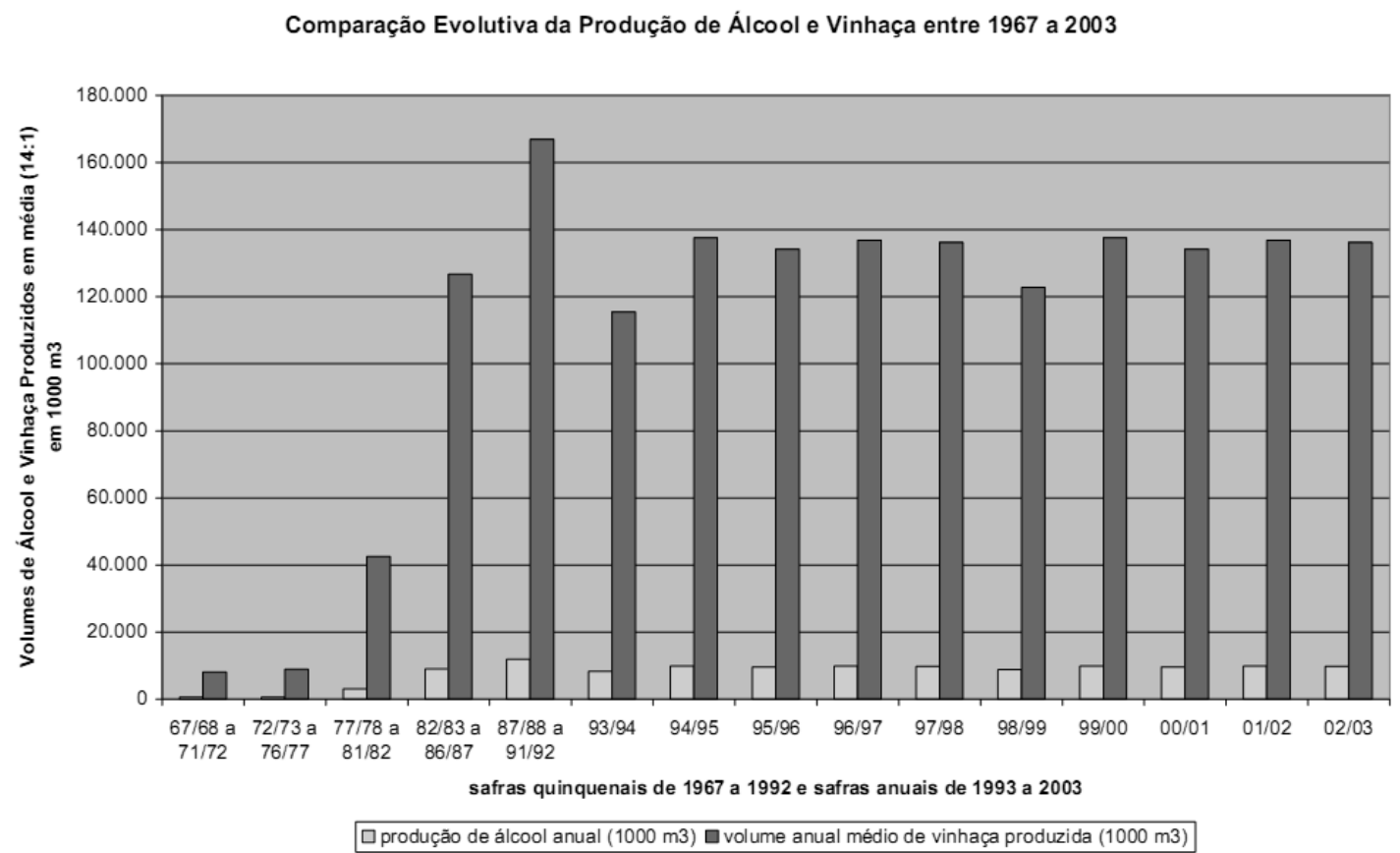

Figura 3.3 - Comparação Evolutiva da Produção de Álcool e Vinhaça entre 1967 e 2003 Fonte: UNICA e UDOP (2005).

Mesmo diante das vantagens proporcionadas pela adoção da fertirrigação, restam ainda dúvidas quanto à adequação da prática do ponto de vista da proteção dos recursos naturais, principalmente no que diz respeito a seus efeitos de longo prazo. $\mathrm{O}$ uso de volumes elevados de vinhaça pode aumentar o nível de potássio no caldo da cana. Além disso, há controvérsias sobre salinização do solo e contaminação de aquíferos subterrâneos. Se os 
efeitos da descarga da vinhaça sobre os mananciais de superfície são bastante conhecidos a ponto de não mais suscitarem disputas, o mesmo parece não ocorrer com os impactos ambientais de sua disposição no solo (CORAZZA, 1999).

\subsubsection{Alternativas ao tratamento da vinhaça}

Em citação ao trabalho de LUKSENBERG et al., (1980) ${ }^{4}$, VIANA (2006) mostra várias possibilidades de tratamento e aproveitamento da vinhaça, tais como:

I. tratamentos físico-químicos - coagulação, floculação e sedimentação com baixo consumo de energia e remoção de DQO de até $50 \%$, havendo inclusive remoção de cor;

II. osmose reversa - a vinhaça é passada por pressão por uma membrana seletiva, no permeado há redução na DQO de 90\%. É um processo caro com grande consumo energético e dificuldade em encontrar uma membrana adequada;

III. evaporação - para atingir cerca de 60 Brix, deixando a vinhaça com consistência pastosa;

IV. incineração - sistema de reação em leito fluidizado. Apesar de reaproveitar os sais minerais nas cinzas, é economicamente inviável;

V. reciclagem industrial - a vinhaça gerada é usada até 15 vezes para diluir o melaço antes da fermentação, isto reduz o volume de vinhaça para 1 a 2 litros/litro de álcool destilado;

VI. lagoas aeróbias de jacinto - a planta aquática, conhecida vulgarmente como Jacinto (aguapé), e a biomassa vegetal produzida a partir da remoção da matéria orgânica e nutriente da vinhaça, pode ser aproveitada na ração animal ou para produção de biogás;

VII. lagoas de estabilização - o resíduo pode ser estabilizado com prazo de até 9 meses por ação fermentativa natural, onde há desprendimento de gases com odor desagradável, infiltrações e contaminações do lençol freático;

VIII. filtros biológicos - biodegradação anaeróbia;

\footnotetext{
${ }^{4}$ LUKSENBERG, J. M.; SÁ. A., DURSO, M. N. Processo para a produção de álcool combustível, sem vinhoto. Relatório Descritivo da patente de invenção. Dyna Engenharia S.A., 1980.
} 
IX. produção de biomassa proteica fúngica ou unicelular - necessidade de tratamento posterior;

X. digestão anaeróbia - produção de gás metano durante a degradação anaeróbia da vinhaça;

XI. fertirrigação - a vinhaça in natura é utilizada na lavoura para reaproveitamento do nitrogênio, fósforo e potássio, como já explanado anteriormente.

Entretanto, de todos os tratamentos citados acima, a fertirrigação é a mais difundida e utilizada, devido à sua viabilidade técnica e econômica. Pesquisas sobre a viabilidade dos tratamentos físico-químico e digestão anaeróbia estão sendo realizadas, mas os resultados ainda não foram amplamente utilizados pelas usinas de processamento de cana-de-açúcar.

Nos itens 3.3 e 3.4 serão explicados detalhadamente dois tipos de tratamentos possíveis para a vinhaça, o físico-químico e a digestão anaeróbia, pois são o foco de estudo nesta dissertação.

\subsection{O Tratamento Físico-Químico}

O emprego do tratamento físico-químico da vinhaça se apresenta como uma boa alternativa, dado seu potencial de tratamento. De fato, quando se adotam os processos de coagulação e floculação, objetiva-se com estas técnicas a redução da DQO do sobrenadante, arrastando para o lodo formado as partículas coloidais presentes na vinhaça, onde se concentra parte da matéria orgânica, para aproveitá-la como fertilizante.

GONÇALVES e SILVA (2000) realizaram testes com dois coagulantes, o óxido de cálcio $(\mathrm{CaO})$ e o sulfato de ferro II $\left(\mathrm{FeSO}_{4}\right)$, verificando a eficiência na remoção de DQO de cada um. Com esta aplicação de coagulantes chegou-se a remoções de DQO na faixa de 30$52 \%$.

SANTIAGO, GIRARDI e GIMENES (2009) realizaram testes de coagulação e floculação na vinhaça utilizando três diferentes coagulantes naturais: Quitosana (polímero modificado derivado da quitina), Tanino (polímeros biodegradáveis aniônicos obtidos de plantas como casca do carvalho, do castanheiro, noz-de-galha etc.) e Moringa (Moringa oleifera). A Quitosana apresentou uma redução de $29 \%$ da DQO, $78 \%$ da cor e $97 \%$ da turbidez. O Tanino resultou em uma eficiência de 35\% na remoção de DQO, $87 \%$ da cor e 
98\% da turbidez, sendo este o coagulante que apresentou maior rendimento na remoção destes parâmetros. Já a Moringa, uma planta tropical de grande relevância medicinal e industrial, apresentou uma remoção de $28 \%$ de DQO, $78 \%$ de cor e $90 \%$ de turbidez. Os autores destacam a eficiência do Tanino na remoção de cor e turbidez, $87 \%$ e $98 \%$, respectivamente, e sugerem o uso de coagulantes naturais como pré-tratamento da vinhaça à outro método que reduza ainda mais a DQO, por exemplo, a digestão anaeróbia.

SAPLA (2012) comparou resultados obtidos com testes de coagulação e floculação de um biopolímero experimental à base de cálcio (o mesmo utilizado nesta pesquisa), com coagulantes comerciais disponíveis no mercado, como o óxido de cálcio $(\mathrm{CaO})$, sulfato férrico $\left(\mathrm{Fe}_{2}\left(\mathrm{SO}_{4}\right)_{3}\right)$ e cloreto férrico $\left(\mathrm{FeCl}_{3}\right)$. Foram comparadas as eficiências de remoção de DQO e a influência no $\mathrm{pH}$ da vinhaça. Variaram-se os parâmetros dosagem do coagulante, rotação das paletas do Jar Test e tempo de mistura (rápida e lenta). A Tabela 3.2 contém os resultados obtidos por SAPLA (2012).

Tabela 3.2 - Dados obtidos na aplicação de diferentes coagulantes à vinhaça.

\begin{tabular}{|c|c|c|c|c|c|c|c|}
\hline \multirow[b]{2}{*}{ Coagulante } & \multirow[b]{2}{*}{$\begin{array}{l}\text { Dosagem } \\
(\mathrm{g} / \mathrm{l})\end{array}$} & \multicolumn{2}{|c|}{ Mistura Rápida } & \multicolumn{2}{|c|}{ Mistura Lenta } & \multirow[b]{2}{*}{$\mathrm{pH}$} & \multirow{2}{*}{$\begin{array}{c}\text { Eficiência } \\
\text { de } \\
\text { Remoção } \\
\text { de DQO } \\
(\%)\end{array}$} \\
\hline & & $\begin{array}{l}\text { Rotações } \\
\text { por } \\
\text { Minuto } \\
\text { (rpm) }\end{array}$ & $\begin{array}{l}\text { Tempo } \\
\text { de } \\
\text { Mistura } \\
\text { (min) }\end{array}$ & $\begin{array}{c}\text { Rotações } \\
\text { por } \\
\text { Minuto } \\
\text { (rpm) }\end{array}$ & $\begin{array}{l}\text { Tempo } \\
\text { de } \\
\text { Mistura } \\
\text { (min) }\end{array}$ & & \\
\hline Biopolímero & 14,0 & 200 & 0,50 & - & - & natural & 25,12 \\
\hline $\mathrm{CaO}$ & 18,0 & 200 & 1,0 & - & - & natural & 18,83 \\
\hline $\mathrm{FeCl}_{3}$ & 4,5 & 200 & 10,0 & 80 & 10,0 & natural & 23,24 \\
\hline $\mathrm{Fe}_{2}\left(\mathrm{SO}_{4}\right)_{3}$ & 4,0 & 200 & 10,0 & 80 & 10,0 & natural & 21,40 \\
\hline
\end{tabular}

Fonte: Adaptado de SAPLA (2012).

Como relatado pelos trabalhos supracitados, o tratamento físico-químico é uma alternativa interessante para o tratamento da vinhaça. Pode-se usar esta forma de tratar a vinhaça como complemento a outro tipo de tratamento, por exemplo, o anaeróbio.

\subsection{A Digestão Anaeróbia}

A biodigestão anaeróbia é uma alternativa de aproveitamento energético da vinhaça, por ser economicamente viável e um efetivo meio de remoção da carga orgânica, pois produz 
biogás, que é um combustível prontamente utilizado pela indústria de álcool (WILKIE, RIEDESEL e OWENS, 2000)

Para o leitor interessado nos processos relacionados à digestão anaeróbia, recomenda-se as seguintes publicações:

- Reatores Anaeróbios (Livro). Autor: Carlos A. L. Chernicharo. $2^{\mathrm{a}}$ Edição Ampliada e Revisada (2008). Editora UFMG. Este livro explicita os fundamentos da digestão anaeróbia, a questão da biomassa, apresenta os principais sistemas de tratamento e, didaticamente, demonstra projetos de reatores anaeróbios, controle operacional, e de sistemas de pós-tratamento.

- Tratamento de Esgotos Sanitários por Processo Anaeróbio e Disposição Controlada no Solo (Livro) - PROSAB. Coord. José Roberto Campos. $1^{\text {a }}$ Edição (1999). Neste exemplar pode-se encontrar, além de uma descrição sucinta dos fundamentos do tratamento anaeróbio, uma coletânea de trabalhos técnicos no assunto. Pode-se adquirir esta e outras publicações do PROSAB gratuitamente pelo endereço na web: http://www.finep.gov.br/prosab/produto.

Além destas duas obras supracitadas, pode-se facilmente encontrar artigos em periódicos, dissertações e teses sobre o tema da digestão anaeróbia em bibliotecas e na internet.

\subsubsection{A Digestão Anaeróbia da Vinhaça}

Neste item serão elucidados apenas fatores relevantes sobre a digestão anaeróbia da vinhaça, pois o esclarecimento do processo em si pôde ser indicado no item anterior.

O processo de biodigestão anaeróbia consiste na biodegradação de sua carga orgânica. Este processo gera biogás e um efluente com reduzida carga orgânica, que pode ser reaproveitado como fertilizante.

Apesar de a vinhaça apresentar caráter ácido, após sua introdução no reator, devido ao consumo dos ácidos orgânicos e formação de compostos como amônia, ocorre rápida elevação do pH do meio reacional sem necessidade de adição de compostos alcalinos. 
Com relação aos nutrientes básicos para suprimento das necessidades dos microrganismos presentes no reator, de uma forma geral o conteúdo de nitrogênio, fósforo e micronutrientes da vinhaça são adequados para o bom desenvolvimento do processo.

Observa-se, ainda, que o lodo anaeróbio possui baixa taxa de autoconsumo, mesmo em prolongados períodos de inatividade, sendo capaz de conservar sua atividade específica com a mesma intensidade anterior à paralisação. Essa característica do reator permite sua volta ao funcionamento após os períodos de entressafra sem que ocorra a necessidade de substituir ou readaptar o lodo biológico.

O potencial de geração de biogás a partir da vinhaça é variável conforme seu conteúdo de matéria orgânica biodegradável durante o processo. Segundo POMPERMAYER (2000), nos caso de resíduos concentrados como a vinhaça, a produção livre de biogás é alta em relação às sobras dissolvidas. A proporção de $\mathrm{CH}_{4}$ no biogás produzido é de 55 a $65 \%$, sendo o restante constituído principalmente por $\mathrm{CO}_{2}$.

O reator UASB possui uma configuração que, através da retenção dos microrganismos auto-imobilizados, permite a manipulação independente dos tempos de retenção celular e hidráulica, sendo possível sua operação com tempo de retenção hidráulica de poucas horas. Isto proporciona, em decorrência, a redução dos volumes e custos envolvidos na aplicação.

O reator UASB conjuga fundamentalmente as propriedades de elevada sedimentabilidade do lodo e o uso de um separador das fases sólidas, líquidas e gasosas, na sua parte superior. Esse reator possibilita a formação, em seu interior, de três regiões distintas, com comportamentos dinâmicos característicos embora inter-relacionados. No fundo do reator forma-se um leito biológico constituído de material de alta sedimentabilidade, o qual é sobreposto por uma região constituída de material biológico, com menor grau de sedimentabilidade em relação ao leito inferior. A terceira região, já interna ao separador, tem características que permitem a floculação e o retorno do lodo para a zona ativa do reator. Dessa forma a perda de microrganismos é drasticamente reduzida e apenas o lodo em suspensão deixa o sistema.

Podem ser observadas taxas de aplicação, parâmetro que melhor caracteriza a eficiência de um reator, representando a quantidade de matéria orgânica que pode ser introduzida por unidade de volume do reator e de tempo, atingindo valores de até $20 \mathrm{~kg}$ DQO/m³.dia/reator (GRANATO, 2003). 
A Usina São Martinho, em Pradópolis-SP, utiliza da tecnologia de digestão anaeróbia da vinhaça e se mostra como um exemplo nesta área, visto que ainda são poucas usinas no Brasil que promovem o processamento biológico da vinhaça.

O reator UASB da Usina São Martinho opera na faixa termofílica $\left(55\right.$ a $75^{\circ} \mathrm{C}$ ), possui um volume de $5200 \mathrm{~m}^{3}$, com dimensões de $34 \mathrm{~m}$ de diâmetro e $6 \mathrm{~m}$ de altura, totalmente fabricado na usina. Embora já tenha processado sem problemas $21 \mathrm{~kg} \mathrm{DQO} / \mathrm{m}^{3} \mathrm{dia}$, com uma vazão de $170 \mathrm{~m}^{3} / \mathrm{h}$ (PINTO, 1999).

\subsubsection{Reatores Híbridos}

O emprego de sistemas de tratamento de esgoto sanitário por meio de reatores anaeróbios ocupa uma posição de destaque em nosso país. A evolução da tecnologia no desenvolvimento de reatores anaeróbios impulsionou a pesquisa de configurações que permitissem alcançar alta eficiência na remoção da matéria orgânica em tanques de dimensões cada vez menores e em curtos períodos de tempo. Deste modo surgiram várias combinações de reatores, como o caso do reator anaeróbio híbrido - UAHB, formado pela associação do reator anaeróbio de fluxo ascendente e manta de lodo - UASB e o filtro anaeróbio de fluxo ascendente (LOPES, RIBEIRO e TERAN, 2009).

A utilização desse reator híbrido procura combinar as vantagens e minimizar as desvantagens do UASB e do filtro anaeróbio em um só reator (GUIOT e VAN DEN BERG, 1984). Desta maneira, busca-se uma configuração capaz de acumular na câmara inferior, elevadas concentrações de biomassa, eventualmente granulada, que permanece no reator pela existência de uma camada de enchimento colocada na parte superior, servindo como separador de gás-sólido-líquido e auxiliando na retenção do lodo. Esta configuração deve propiciar, também, uma zona de polimento do efluente, aumentando a estabilidade do processo mesmo sob condições de operação transientes (CRAVEIRO, 1994).

Escassas são as informação sobre o uso de reatores anaeróbios híbridos no tratamento da vinhaça estão disponíveis na literatura. Portanto, acredita-se que este trabalho seja pioneiro na área de processamento anaeróbio de vinhaça utilizando reatores anaeróbios híbridos. 


\subsubsection{Potencias Inibidores da Biodigestão Anaeróbia da Vinhaça}

A digestão anaeróbia da vinhaça, apesar de viável tecnicamente e ter possibilidade de geração de energia alternativa, pode ser limitada pela presença de compostos inibidores, como compostos fenólicos, que limitam severamente o processo de degradação anaeróbia da vinhaça. Estes compostos reduzem a cinética química do processo de digestão anaeróbia, reduzem as concentrações de metano produzidas, a vazão do gás, e coeficientes cinéticos de degradação, acumulando os ácidos orgânicos no interior do reator e exercendo uma série de eventos que podem infligir o colapso do processo.

Muitos compostos fenólicos são conhecidos por serem tóxicos aos processos de digestão anaeróbia, afetando diretamente a atividade das arqueas metanogênicas. Diversos autores observaram a presença dessa toxicidade provocada pela presença ou produção desses compostos inibidores na digestão anaeróbia da vinhaça e outros resíduos industriais, fazendose necessário a adoção de tempos de detenção hidráulicos maiores (PEARSON et al., 1980; BRITZ et al., 1992; JIMÉNEZ et al., 2003).

Além disso, os principais inibidores em potencial encontrados na vinhaça são os íons dos compostos de enxofre e o potássio solúvel, que apresentam concentrações mais críticas nas vinhaças oriundas de mosto de melaço e misto de caldo e melaço (TOLEDO, 2001).

Ressalta-se que o sulfato como tal não é um inibidor de processo, mas este composto, ao ser utilizado pelas bactérias redutoras do enxofre, também presentes no reator anaeróbio, é transformado em sulfeto, o qual em sua forma solúvel é um agente inibidor em concentrações da ordem de $200 \mathrm{mg} / \mathrm{l}$. A inibição será então função do equilíbrio resultante no sistema entre as formas solúvel, insolúvel e gasosa do sulfeto (PINTO, 1999). 


\section{METODOLOGIA}

Neste capítulo, estão descritos os materiais e os métodos utilizados, assim como os procedimentos para acompanhamento e avaliação do sistema anaeróbio, composto por um Reator Anaeróbio Híbrido de Biomassa e Imobilizada (RAHBI) ${ }^{5}$ em escala de bancada alocado em câmara de madeira com temperatura controlada $\left(30^{\circ} \mathrm{C}\right)$.

Esta pesquisa envolveu as seguintes etapas:

- Dimensionamento e montagem do sistema: RAHBI, câmara de temperatura controlada e sistema de medida de biogás, bem como a aquisição de um Jar Test para a aplicação do biopolímero experimental como coagulante da vinhaça;

- Operação do sistema, construído em escala de laboratório, no tratamento físicoquímico e no processamento anaeróbio da vinhaça;

- Análise dos dados obtidos durante a operação, para tomada de decisões mitigadoras de problemas operacionais;

- Avaliação do desempenho do sistema anaeróbio para remoção de matéria orgânica carbonácea e produção de biogás;

- Avaliação do efeito da aplicação do biopolímero experimental como pré-tratamento físico-químico da vinhaça.

- Análise comparativa entre os reatores nos âmbitos da:
- eficiência de remoção de matéria orgânica;
○ geração de alcalinidade em bicarbonato;
○ geração de ácidos orgânicos voláteis e íons (ânions e cátions);
○ produção de biogás;
○ biologia molecular e;
- morfologia e característica do lodo granular.

\footnotetext{
${ }^{5}$ Os reatores anaeróbios utilizado neste estudo têm o princípio de um reator UASB, mas devido a questões técnicas e operacionais na concepção do reator, optou-se por utilizar um material suporte como um dos componentes separadores no interior do reator. Este material suporte desempenhou a função de separar o material sólido afluente ao reator.
} 


\subsection{Concepção do Sistema}

A instalação e operação do sistema de processamento anaeróbio foram feitas no Laboratório de Biotoxicologia em Águas Continentais e Efluentes (BIOTACE) da Universidade de São Paulo (Campus I) em São Carlos (EESC/USP).

\subsubsection{Tratamento Físico-químico}

Os ensaios de coagulação, floculação e sedimentação foram realizados no Jar Test apresentado na Figura 4.1. Inicialmente adicionou-se 2,0 1 de vinhaça em cada uma das seis cubas que compõem o equipamento. Em seguida, agitou-se a vinhaça a uma rotação de 200 rpm e aplicou-se o biopolímero, deixando em mistura rápida por um minuto.

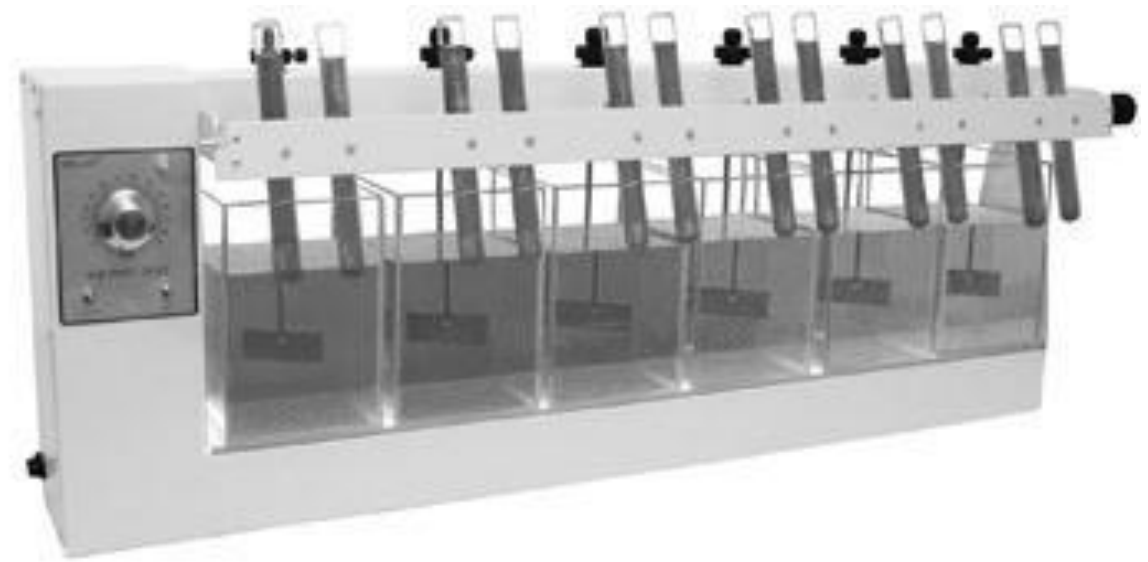

Figura 4.1 - Jar Test utilizado para a aplicação do biopolímero experimental na vinhaça.

Adotou-se, para este estudo, a dosagem de 14 g/l do biopolímero experimental. Esta decisão se baseou em estudos prévios de aplicação deste coagulante, quando foram aplicadas cinco dosagens do coagulante $(10,12,14,16$ e $18 \mathrm{~g} / \mathrm{l})$, e tempo de sedimentação de uma hora. Escolheu-se aquela dosagem que apresentou uma remoção de cor satisfatória, mas uma produção de lodo não elevada (Figura 4.2). A decisão, inicialmente visual, foi corroborada por resultados de análises de DQO e turbidez nas dosagens testadas, confirmando a escolha da dosagem a ser utilizada para a coagulação da vinhaça antes de ser encaminhada para o reator 2. 


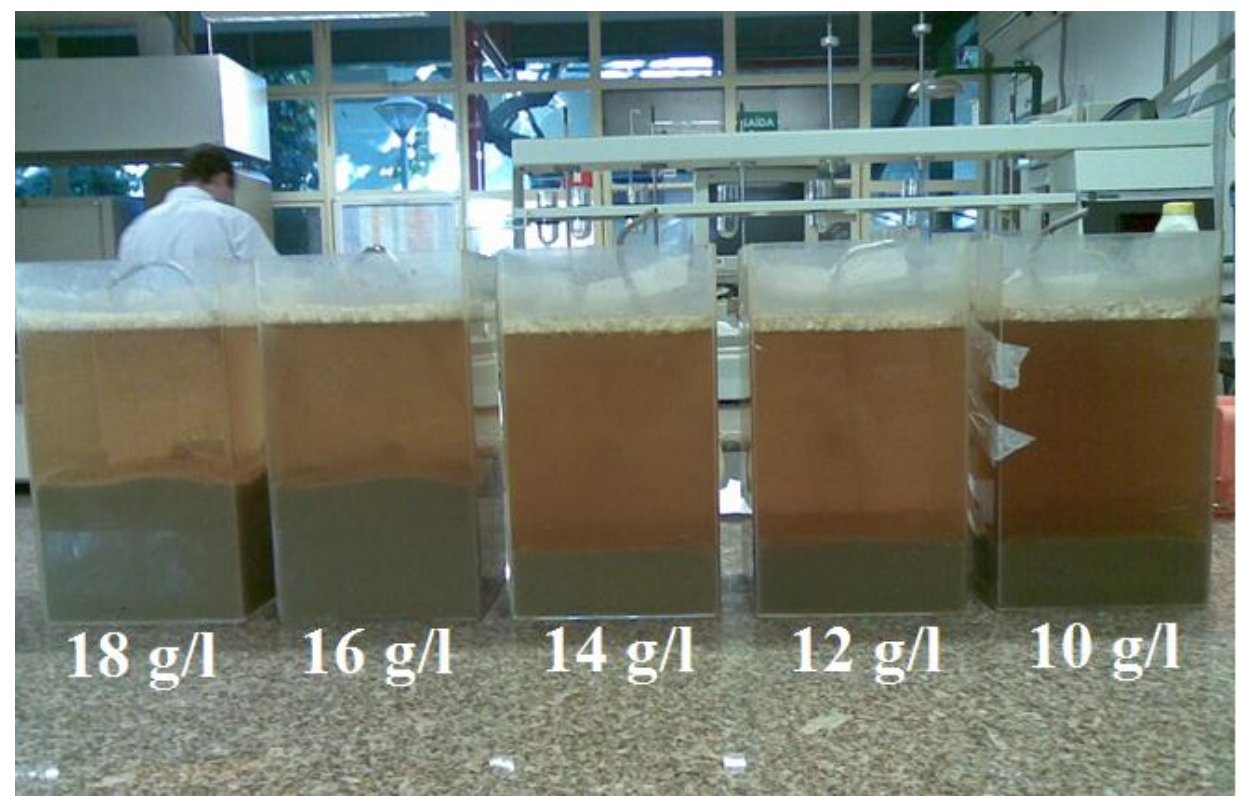

Figura 4.2 - Clareamento da vinhaça após 1h de sedimentação utilizando o biopolímero experimental como agente coagulante.

\subsubsection{Biopolímero Experimental ${ }^{6}$}

O biopolímero consiste em um produto de base natural, obtido pela reação enzimática entre um polissacarídeo extraído de algas e óxido de cálcio. Trata-se de uma tecnologia versátil, na qual em função do tratamento a ser executado é definido o peso molecular do polissacarídeo obtido. Essa etapa é extremamente importante, pois o tipo de nutrição e a condição de luminosidade define o tamanho da cadeia polissacarídica produzida pelas algas. Esse polissacarídeo, devido ao tamanho da cadeia, pode ter características anfóteras, não sendo um catiônico real, mesmo devido à presença do cálcio. Independente do meio iônico, o biopolímero tem funcionalidade.

A tecnologia do biopolímero experimental é baseada no conceito de geração de um polieletrólito a partir da extração e indução enzimática de microalgas da espécie Spirillum Calcium. O biopolímero possui função catiônica devido à formação de um complexo via oxidação com óxido de cálcio, formando um sistema de coagulação, floculação e neutralização de odores gerados em processo de tratamento aeróbio e anaeróbo de matéria orgânica. De uma forma simplificada, os íons de cálcio têm a característica de formar

\footnotetext{
${ }^{6}$ Texto fornecido pelo produtor do biopolímero.
} 
agregados, e com o aumento do $\mathrm{pH}$, fazem com que o polissacarídeo formado pelas micro algas, funcionem como uma tela que arrasta e rastreia as partículas orgânicas ou minerais, desencadeando o processo de floculação e neutralização de odores. As Figuras 4.3 e 4.4 ilustram o processo que ocorre nos tratamentos com essa tecnologia.

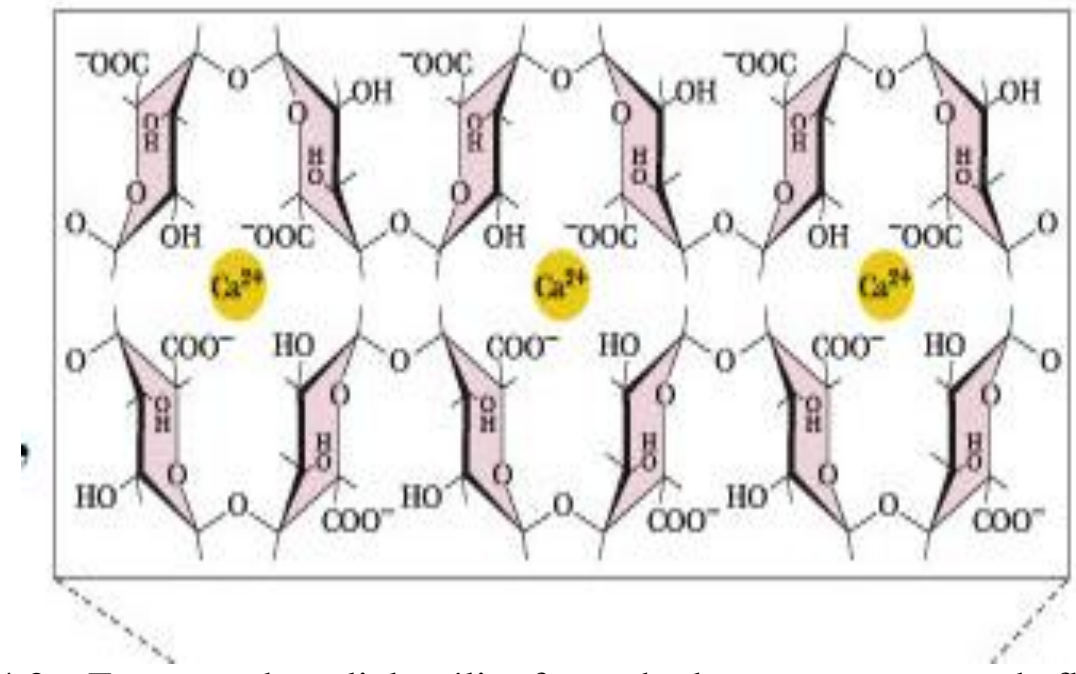

Figura 4.3 - Estrutura do polieletrólito formado durante o processo de floculação.

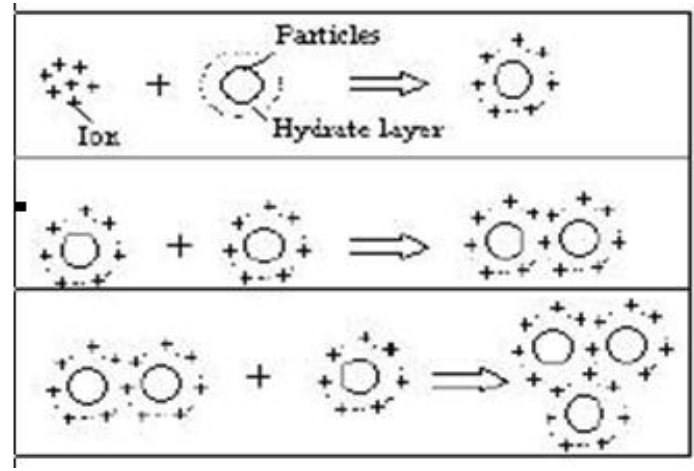

Figura 4.4 - Princípio de formação dos agregados.

Quando esse material é adicionado a efluentes, devido a formação de agregados e aumento do $\mathrm{pH}$, o polieletrólito se distende, formando estrutura do tipo rede de complexação, arrastando os sólidos em suspensão ou os íons liberados pelas reações químicas de degradação, fazendo com isso a clarificação do resíduo e, devido ao sequestro da matéria orgânica, a redução de DQO ou DBO (Texto fornecido pelo fornecedor do biopolímero experimental). ${ }^{7}$

\footnotetext{
${ }^{7} \mathrm{O}$ produtor do biopolímero solicitou que sua empresa não posse citada, pois trata-se ainda de um produto experimental.
} 


\subsubsection{Reator Anaeróbio Híbrido em Escala de Bancada}

Os reatores, do tipo anaeróbio híbrido de biomassa e imobilizada (RAHBI), de bancada utilizados nesta pesquisa foram confeccionados em acrílico com formato cilíndrico, separado em dois compartimentos: o corpo e a parte superior (Figura 4.5). Para o primeiro reator, nominado reator 1 (R1), aplicou-se vinhaça sem tratamento prévio, e ao segundo reator, nominado reator 2 (R2), aplicou-se o sobrenadante do tratamento físico-químico.

As dimensões são mostradas na Figura 4.6 e conferem um volume de 1,5 litros para o reator.

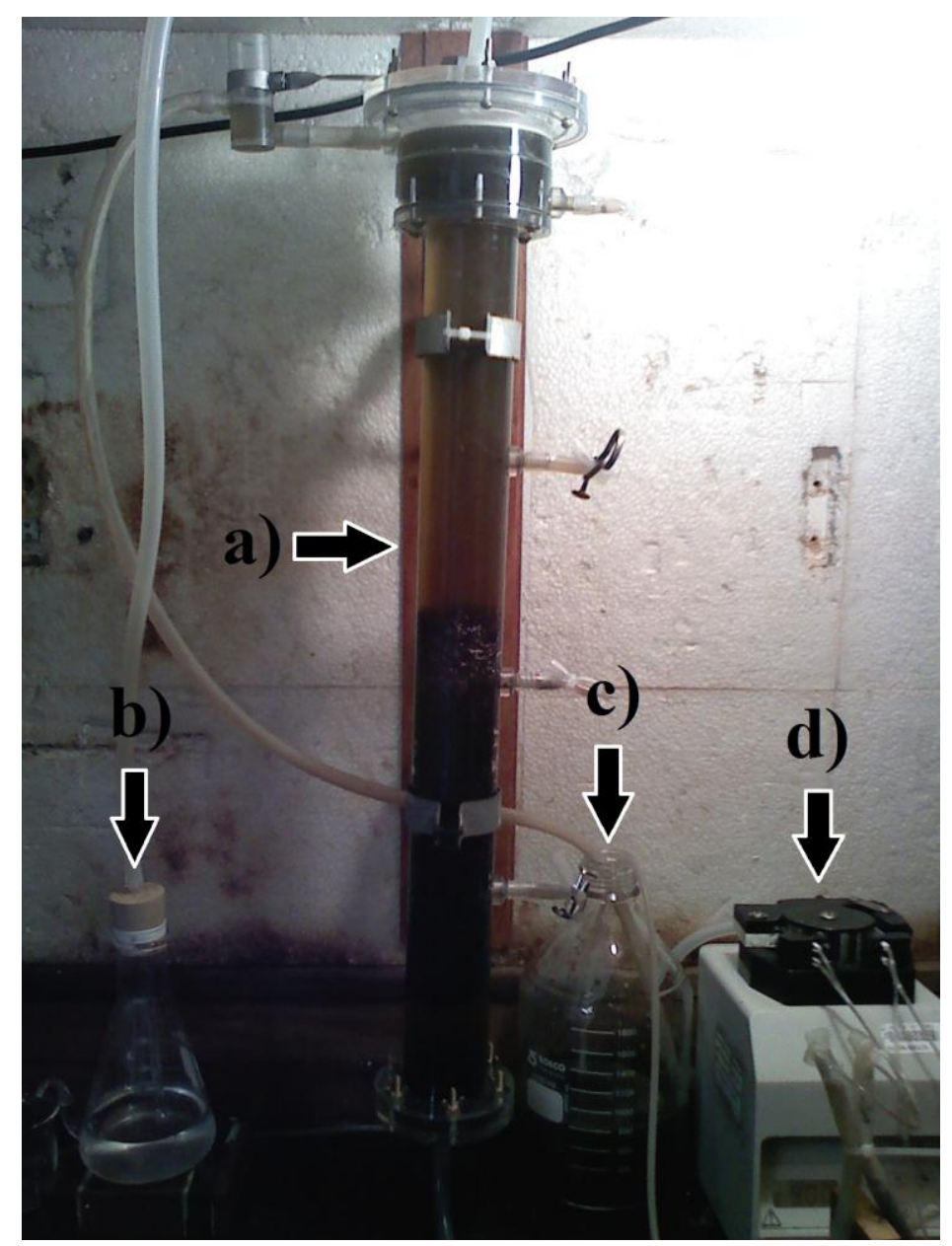

Figura 4.5 - a) Reator Anaeróbio Híbrido de Biomassa e Imobilizada (RAHBI); b) bomba de alimentação de vinhaça; c) frasco de coleta de efluente; d) medidor de gás (frasco de Mariotte). 


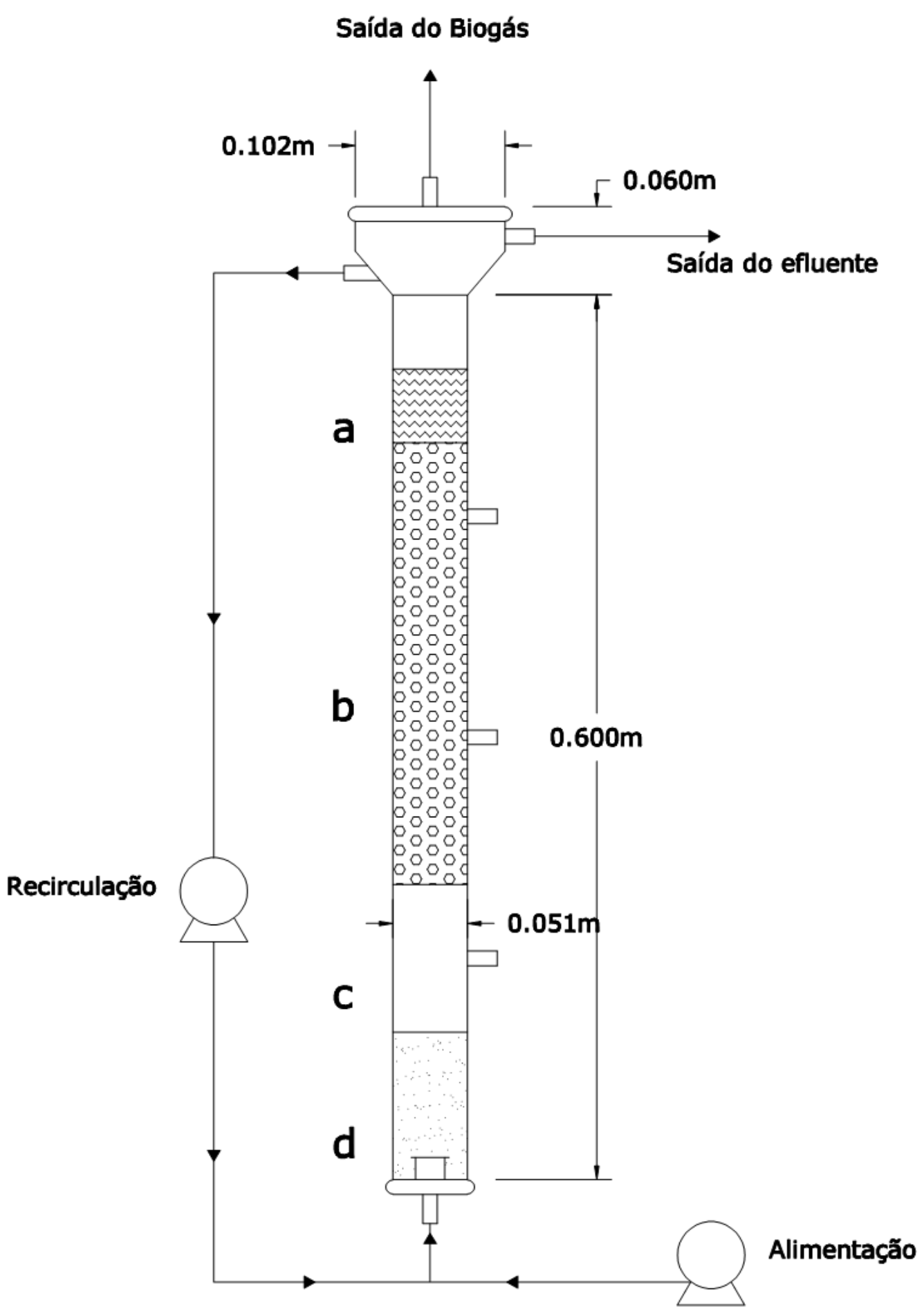

Figura 4.6 - Desenho esquemático do reator anaeróbio híbrido de biomassa e imobilizada. a) Esponja de aço inox; b) biomassa granular imobilizada em material suporte flutuante móvel; c) espaço livre de biomassa; e d) biomassa (floculenta).

Os materiais usados como meio suporte para a biomassa foram discos plásticos de baixa densidade utilizados em reatores do tipo MBBR (Moving Bed Biofilm Reactor) (Figura 4.7). Como a densidade do suporte é menor do que a densidade da vinhaça, utilizou-se uma 
esponja de aço inox (modelo Scotch-Brite - 3M) como anteparo ao conjunto suporte/grânulo, para manter a biomassa completamente imersa.

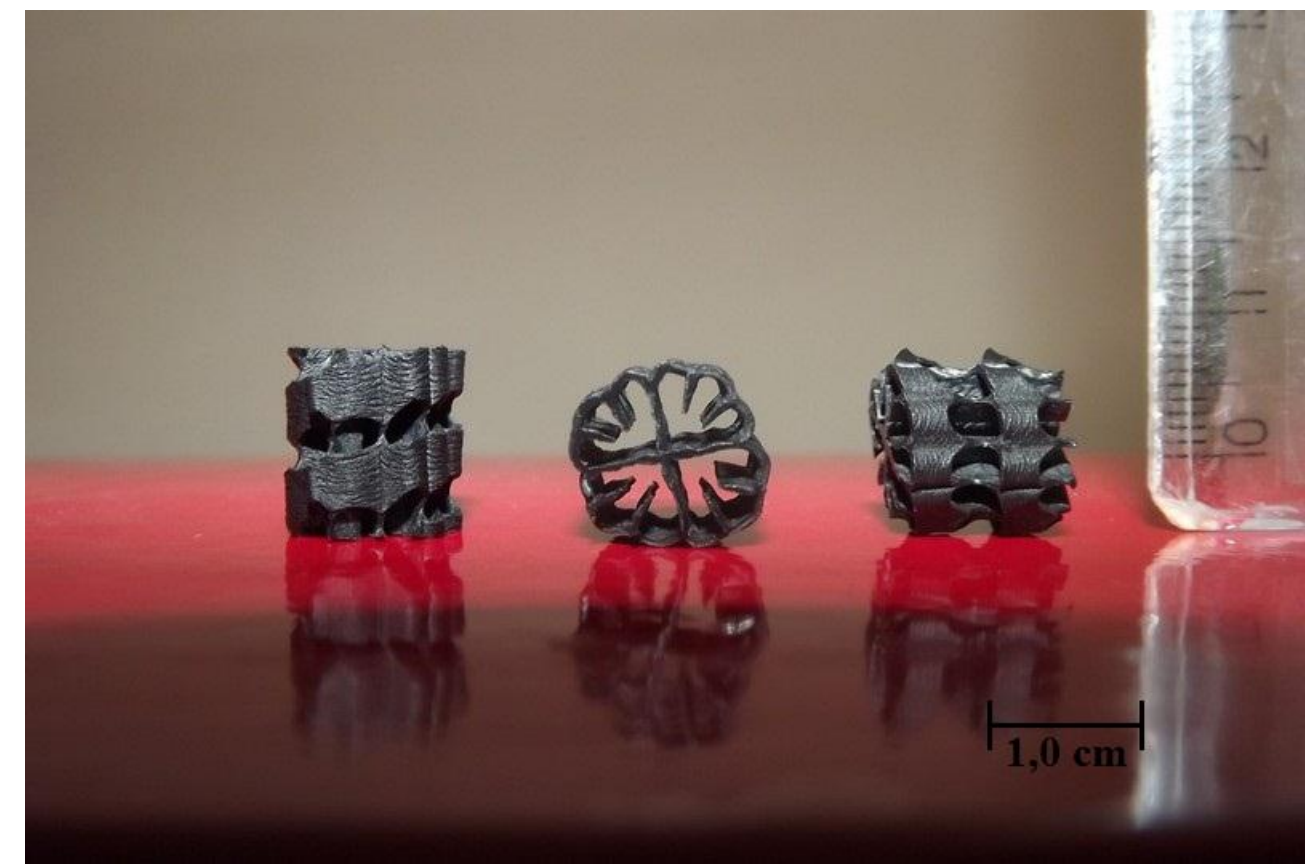

Figura 4.7 - Material utilizado como meio suporte para a biomassa contida nos reatores.

Na seção 4.1.5será explicado o processo e a forma como foi feita a inoculação, e o porquê de o reator possuir biomassa granular e floculenta.

Acima do corpo principal do reator, situa-se o sistema de separação gás/líquido, na forma de tronco de pirâmide invertido. O dispositivo de saída é constituído por tubos submersos que descarregam em um recipiente externo para coleta de amostras. O gás é retirado de dentro da campânula do separador e, após passar por selo hídrico, segue para o sistema de medição.

Foram utilizados dois tipos de bombas que carregavam os reatores de vinhaça. Durante a adaptação do inóculo utilizou-se uma bomba peristáltica da marca Gilson modelo Miniplus 3 com cabeçote duplo. Nesta fase não houve recirculação de parte do efluente, pois a carga de entrada nos reatores era baixa. Após adaptação foram utilizadas quatro bombas dosadoras da marca Grundfos do tipo SMART digital Dosing Pumps, sendo três modelos DDC $(6 \mathrm{ml} / \mathrm{h}-6 \mathrm{l} / \mathrm{h})$ e um DDA $(30 \mathrm{ml} / \mathrm{h}-30$ l/h). Destas bombas, duas foram designadas para a alimentação de vinhaça e duas para a recirculação na proporção de 3:1. A Tabela 4.1 contém os valores médios dos parâmetros de entrada dos reatores. 
Tabela 4.1 - Valores de entrada monitorados nos sistemas de processamento.

\begin{tabular}{ccccc}
\hline Reator & $\begin{array}{c}\text { Vazão } \\
(1 / \mathrm{d})\end{array}$ & $\begin{array}{c}\text { Recirculação } \\
(1 / \mathrm{d})\end{array}$ & $\begin{array}{c}\mathrm{COV} \\
\text { mínima } \\
\left(\mathrm{kg} / \mathrm{m}^{3} \mathrm{~d}\right)\end{array}$ & $\begin{array}{c}\mathrm{COV} \\
\text { máxima } \\
\left(\mathrm{kg} / \mathrm{m}^{3} \mathrm{~d}\right)\end{array}$ \\
\hline $\mathbf{1}$ & 1,00 & 3,00 & 0,92 & 12,89 \\
$\mathbf{2}$ & 1,00 & 3,00 & 0,88 & 10,97 \\
\hline
\end{tabular}

\subsection{4. Água Residuária - Vinhaça}

A água residuária utilizada foi a vinhaça in natura, coletada na Usina São Martinho, em Pradópolis/SP. As coletas foram realizadas em julho, setembro e novembro de 2011, período da safra de 2011/2012, e a vinhaça foi armazenada, durante todo o período de operação, a $4^{\circ} \mathrm{C}$ para evitar alterações em sua característica inicial.

Foram feitas caracterizações da vinhaça a cada coleta e seus volumes separados por lotes, de acordo com a data da coleta.

A Tabela 4.2 mostra a caracterização da vinhaça coletada na Usina São Martinho S/A. Foram feitas três coletas durante a pesquisa, em julho, setembro e novembro de 2011, e os volumes coletados separados em lotes.

Tabela 4.2 - Caracterização dos lotes de vinhaça utilizada no experimento.

\begin{tabular}{|c|c|c|c|c|}
\hline Parâmetros & Unidade & Coleta 1 & Coleta 2 & Coleta 3 \\
\hline$\overline{\mathrm{pH}}$ & - & 4,6 & 4,6 & 4,6 \\
\hline Condutividade & $\mu \mathrm{S} / \mathrm{cm}$ & 14,6 & 12,98 & - \\
\hline Sacarose & $\mathrm{g} / \mathrm{l}$ & 4,4 & 4,1 & - \\
\hline DQO Bruta & $\mathrm{g} / 1 \mathrm{O}_{2}$ & 34,5 & 38,1 & 40,7 \\
\hline DQO Particulada & $\mathrm{g} / 1 \mathrm{O}_{2}$ & 13,1 & 19 & - \\
\hline DQO Solúvel & $\mathrm{g} / \mathrm{l} \mathrm{O}_{2}$ & 10,2 & 14,9 & 27,2 \\
\hline $\mathrm{COT}$ & $\mathrm{g} / \mathrm{l}$ & 10,85 & 13,88 & - \\
\hline NTK & $\mathrm{mg} \mathrm{N} / 1$ & 188,7 & 758 & 853 \\
\hline N. Amoniacal & $\mathrm{mg} \mathrm{N}-\mathrm{NH}_{3} / \mathrm{l}$ & 12,8 & 48 & 55 \\
\hline Nitrito & $\mathrm{mg} \mathrm{N}-\mathrm{NO}_{2} / 1$ & $<0,1$ & $<0,1$ & $<0,1$ \\
\hline Nitrato & $\mathrm{mg} \mathrm{N}-\mathrm{NO}_{3} / \mathrm{l}$ & $<1$ & $<1$ & $<1$ \\
\hline Fósforo & $\mathrm{mg} \mathrm{P}-\mathrm{PO}_{4}{ }^{3+} / 1$ & 243 & 212,5 & 147 \\
\hline Sulfato & $\mathrm{mg} \mathrm{S}-\mathrm{SO}_{4} / \mathrm{l}$ & 1145 & 1200 & 1865 \\
\hline
\end{tabular}


Tabela 4.2 - Caracterização dos lotes de vinhaça utilizada no experimento (continuação).

\begin{tabular}{lcccc}
\hline Parâmetros & Unidade & Coleta 1 & Coleta 2 & Coleta 3 \\
\hline Sódio & $\mathrm{mg} \mathrm{Na} / 1$ & 920 & 970 & 1079,5 \\
Potássio & $\mathrm{mg} \mathrm{K} / 1$ & 4675 & 5525 & 4675 \\
Lítio & $\mathrm{mg} \mathrm{Li} / 1$ & 0,003 & 0,001 & 0,002 \\
Cálcio & $\mathrm{mg} \mathrm{Ca} / 1$ & 1153 & 1675 & 1144 \\
Magnésio & $\mathrm{mg} \mathrm{Mg} / \mathrm{l}$ & 293 & 336 & 312 \\
Zinco & $\mathrm{mg} \mathrm{Zn/l}$ & 0,338 & 1,014 & 0,29 \\
Chumbo & $\mathrm{mg} \mathrm{Pb/1}$ & 0,44 & 0,42 & 0,15 \\
Cromo total & $\mathrm{mg} \mathrm{Cr} / 1$ & 0,108 & 0,035 & 0,112 \\
Cádmio & $\mathrm{mg} \mathrm{Cd} / 1$ & 0,135 & 0,097 & 0,052 \\
Níquel & $\mathrm{mg} \mathrm{Ni} / 1$ & 0,305 & 0,232 & 0,121 \\
Manganês & $\mathrm{mg} \mathrm{Mn} / 1$ & 4,17 & 3,47 & 5,45 \\
Ferro total & $\mathrm{mg} \mathrm{Fe} / 1$ & 14,66 & 12,61 & 18,17 \\
Cobre & $\mathrm{mg} \mathrm{Cu} / 1$ & 0,489 & 0,547 & 0,59 \\
\hline Sólidos & & & & \\
\hline STD & $\mathrm{g} / 1$ & 27,9 & 29,2 & 31,7 \\
ST & $\mathrm{g} / 1$ & 32,0 & 37,1 & 39,5 \\
SVT & $\mathrm{g} / 1$ & 18,8 & 24,4 & 25,3 \\
STF & $\mathrm{g} / 1$ & 13,2 & 12,7 & 14,2 \\
SST & $\mathrm{g} / 1$ & 5,2 & 7,9 & 7,8 \\
SSV & $\mathrm{g} / 1$ & 3,6 & 6,7 & 6,5 \\
SSF & & 1,6 & 1,2 & 1,3 \\
\hline
\end{tabular}

\subsubsection{Inóculo do Reator RAHBI}

O reator foi inoculado com lodo anaeróbio granular proveniente de reator UASB usado no tratamento de água residuária de abatedouro de aves, a Dacar Avícola S/A, situada no município de Tietê, no estado de São Paulo.

A escolha do lodo é justificada por sua utilização em diversas pesquisas no Laboratório de Processos Biológicos (Campus 2) da Universidade de São Paulo em São Carlos (EESC/USP), devido principalmente à grande diversidade microbiana apresentada (HIRASAWA, 2003). 
O lodo granular inicial foi adaptado para o processamento de vinhaça durante a partida do reator. BROWN (2012) analisou as condições de adaptação deste lodo para a vinhaça e concluiu que a adaptação, de um efluente constituído basicamente por material proteico para outro essencialmente carboidrático, foi bem sucedida, e que este inóculo pode ser usado em reatores tratando vinhaça.

Foram utilizados $500 \mathrm{ml}$ de lodo para a inoculação (1/3 do volume do reator) contendo $47 \mathrm{gSSV} / 1$. Antes de aplicar o lodo no reator, $250 \mathrm{ml}$ da biomassa foram macerados em um cadinho e misturados com a parte não macerada, com o intuito de prover um maior contato com o material suporte, facilitando a formação de biofilme. Aplicou-se a mistura grânulo/macerado no reator contendo aproximadamente $500 \mathrm{ml}$ do suporte. A Figura 4.8 contém imagens do lodo granular utilizado como inóculo.

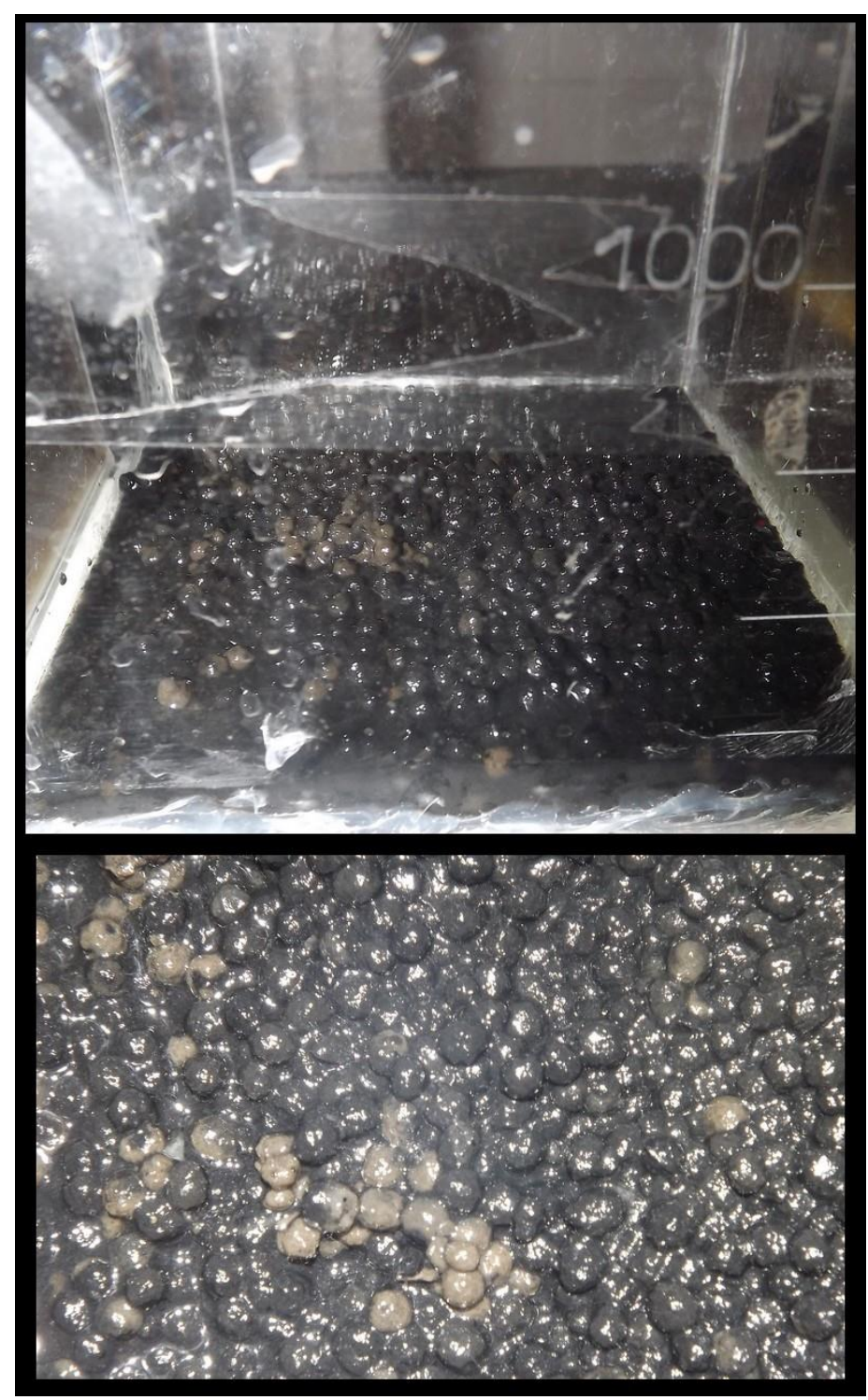

Figura 4.8 - Lodo granular utilizado como inóculo. 


\subsection{Análises de Monitoramento e Caracterização}

\subsubsection{Análises Físico-químicas}

Foram realizadas as seguintes análises físico-químicas das amostras afluente e efluente aos reatores: demanda química de oxigênio solúvel $\left(\mathrm{DQO}_{\mathrm{s}}\right)$, onde as amostras foram previamente filtradas em membranas de fibra de vidro com $45 \mu \mathrm{m}$ de abertura, $\mathrm{pH}$ e alcalinidade total e parcial de acordo com Standard Methods for the Examination of Water and Wastewater (APHA, 2005).

\subsubsection{Cromatografia de ions}

As análises de sulfato foram realizadas por cromatografia de íons, em cromatógrafo Dionex ICS-3000, localizado no Laboratório de Processos Biológicos, no Campus II da Universidade de São Paulo/São Carlos.

\subsubsection{Produção de Biogás}

A produção de biogás foi medida empregando-se o método de deslocamento de líquido utilizando frascos de Mariotte. Em cada reator foi acoplado um frasco de Mariotte como mostrado na Figura 4.9. 


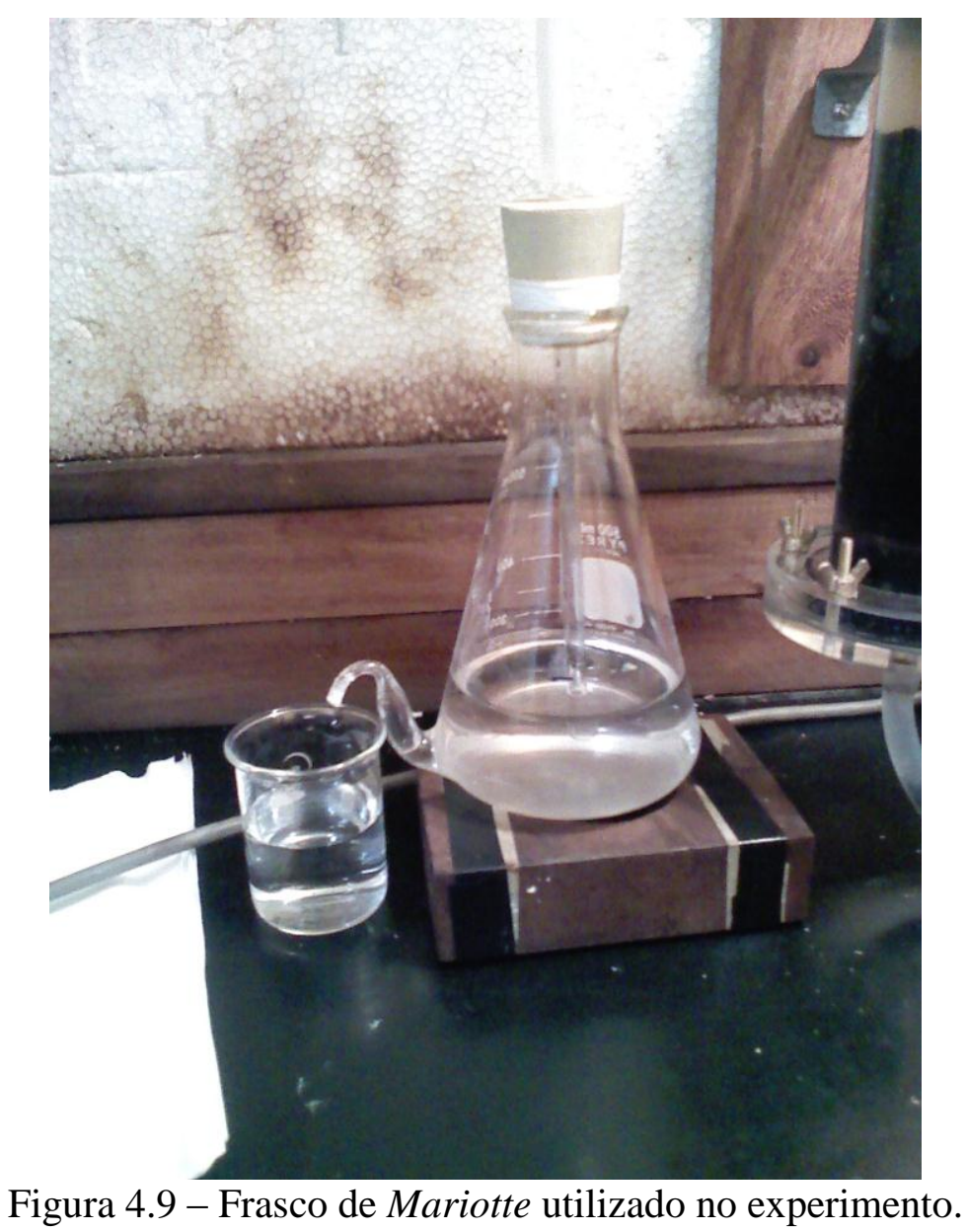

Como o objetivo era o de realizar a medição do gás metano $\left(\mathrm{CH}_{4}\right)$, nos frascos lavouse o biogás com uma solução de soda $\mathrm{NaOH}$ a $15 \%(\mathrm{~m} / \mathrm{v})$, cujo objetivo foi absorver o $\mathrm{CO}_{2}$ presente no biogás, de acordo com as seguintes reações:

$$
\begin{aligned}
& \mathrm{H}_{2} \mathrm{O}+\mathrm{CO}_{2} \leftrightarrow \mathrm{H}_{2} \mathrm{CO}_{3} \\
& \mathrm{H}_{2} \mathrm{CO}_{3}+2 \mathrm{NaOH} \leftrightarrow \mathrm{Na}_{2} \mathrm{CO}_{3}+2 \mathrm{H}_{2} \mathrm{O} \\
& \mathrm{CO}_{2}+2 \mathrm{NaOH} \Rightarrow \mathrm{Na}_{2} \mathrm{CO}_{3}+\mathrm{H}_{2} \mathrm{O}
\end{aligned}
$$

$\mathrm{Na}$ aplicação deste procedimento, considerou-se que o $\mathrm{CO}_{2}$ e o $\mathrm{CH}_{4}$ eram os principais constituintes do biogás. Essa consideração é válida uma vez que em pH neutro a maior parte da amônia $\left(\mathrm{NH}_{3}\right)$ e metade do sulfeto de hidrogênio $\left(\mathrm{H}_{2} \mathrm{~S}\right)$, se presentes, estarão ionizados e dissolvidos na fase líquida como $\mathrm{NH}_{4}{ }^{+}$e $\mathrm{HS}^{-}$(AQUINO, et al., 2007).

Diferentes grupos de pesquisa brasileiros usam esta metodologia (ROCHA et al, 2001; ALVES et al, 2005), e o monitoramento da produção de metano também pode ser feito diariamente. A grande vantagem dessa metodologia é que ela dispensa o cromatógrafo para a quantificação do gás metano. Por isso essa técnica tem baixo custo e pode ser implementada 
em qualquer laboratório de monitoramento, e mesmo em ETEs pequenas sem grande capacidade de infraestrutura.

\subsubsection{Análises do Lodo Granular}

Com o intuito de observar as características dos lodos granulares do inóculo e nos reatores 1 e 2, tratando vinhaça e vinhaça pré-tratada, respectivamente, foram realizadas análises de:

- Resistência mecânica dos grânulos;

- Microscopia Eletrônica de Varredura (MEV) e Espectrometria de Energia Dispersiva de Raios-X (EDS) e

- Biologia molecular.

É importante ressaltar que as amostras foram coletadas somente ao fim da operação dos reatores, e a amostra do lodo do inóculo permaneceu em câmara de temperatura controlada em $4^{\circ} \mathrm{C}$.

\subsubsection{Resistência mecânica dos Grânulos}

Para avaliar a resistência dos grânulos foi utilizado um agitador Jar Test, modelo- JT - 102/6. Foram utilizados dez mililitros de amostras do lodo granular empregado como inóculo, assim como os grânulos dos reatores 1 e 2, em jarros com capacidade de $2000 \mathrm{ml}$. Os jarros foram completados com água até o volume de $1000 \mathrm{ml}$. Posteriormente foi aplicada agitação com velocidade de 200 rpm, durante 30 minutos. Após a agitação se deixaram os jarros em repouso, para conseguir a sedimentação dos grânulos e seus fragmentos. Desta foram coletados os grânulos num volume total de $50 \mathrm{ml}$.

Foram feitas imagens dos grânulos dispostos em Placas de Petri em um fotocopiador (scanner) HP G4050 em modo de escaneamento de filme em alto contraste. As áreas médias dos grânulos foram medidas pelo programa Sigma Scan Pro 5.0. 
Por comparação entre os tamanhos dos grânulos antes e após a aplicação do teste foi possível avaliar, indiretamente, de forma qualitativa a resistência dos grânulos ao cisalhamento.

Este experimento foi realizado de acordo com a descrição de TERRY-BROWN (2012), adaptado de (PEREBOOM, 1997).

\subsubsection{Análise estatística dos grânulos submetidos ao teste de resistência mecânica}

Foi realizado o teste $\mathrm{t}$ de Student, que verifica a relação entre duas médias populacionais, neste caso, as amostras dos grânulos antes e depois dos ensaios de resistência mecânica dos grânulos.

O objetivo deste teste foi verificar se duas populações, supõe-se população 0 e população 1, apresentam um mesmo valor médio para uma determinada característica, isto é deseja-se verificar se $\mathrm{m}_{0}=\mathrm{m}_{1}$, sendo 0 as amostras antes dos teste de resistência e 1 as amostras depois do teste de resistência mecânica dos grânulos. Com esta finalidade é necessário obter uma amostra de cada população. As amostras dos grânulos são dependentes uma da outra, logo o teste realizado foi um teste de hipóteses para o caso de duas amostras dependentes.

Para realizar estes testes foi utilizado o software SigmaStat 3.5, com os seguintes termos de hipóteses estatísticas:

$$
\begin{aligned}
& \mathrm{H}_{0}: \mathrm{m}_{0}-\mathrm{m}_{1}=0 \quad \text { versus } \\
& \mathrm{H}_{\mathrm{a}}: \mathrm{m}_{0}-\mathrm{m}_{1}>0 .
\end{aligned}
$$

Em que, $\mathrm{H}_{0}=$ hipótese nula, $\mathrm{H}_{\mathrm{a}}=$ hipótese alternativa, $\mathrm{m}_{0}=$ média da área dos grânulos antes do teste de resistência mecânica dos grânulos, e $\mathrm{m}_{1}=$ média da área dos grânulos depois do teste de resistência mecânica dos grânulos.

Considerou-se a média das áreas dos grânulos antes dos testes de resistência dos grânulos maior do que a média dos grânulos após o teste de resistência mecânica. Esta consideração baseou-se na hipótese de que a aplicação de uma força cisalhante aos grânulos causaria um desgaste da superfície do grânulo, ou até a total destruição dos grânulos. 


\subsubsection{Microscopia Eletrônica de Varredura (MEV)}

Foi utilizado o Microscópio Eletrônico de Varredura TMP Phillips (XL-30), localizado no Laboratório de Caracterização Estrutural (LCE) da Universidade Federal de São Carlos (UFSCar). Esta técnica foi utilizada para a determinação de duas análises:

- Obtenção de imagens para a observação das características estruturais da superfície dos grânulos;

- Estimativa da composição química dos grânulos por meio de EDS

\subsubsection{Técnicas de Biologia Molecular}

A caracterização qualitativa da comunidade microbiana dos lodos granulares foi realizada por meio da técnica de reação em cadeia da polimerase (PCR) seguida da eletroforese em gel de gradiente desnaturante (DGGE) nas amostras do inóculo, da manta de lodo e dos grânulos imobilizados no material suporte.

A técnica de PCR/DGGE consiste nas seguintes etapas: a) extração do DNA ribossomal, b) amplificação por reação em cadeia da polimerase do fragmento de interesse, c) separação do fragmento-alvo pela desnaturação parcial da dupla hélice. Esta metodologia está descrita detalhadamente em SAKAMOTO et al. (2005), DUARTE (2006), SARTI, et al. (2006), SAAVEDRA (2007) e HIRASAWA (2007).

As análises de PCR/DGGE, bem como o uso do software BioNumerics para interpretação das bandas, foram realizadas no Laboratório de Processos Biológicos, localizado no Campus II da Universidade de São Paulo/São Carlos. 


\section{RESULTADOS}

Neste capítulo estão apresentados e discutidos os resultados obtidos durante todo o período de operação dos reatores. Inicialmente o experimento foi projetado para ser contínuo, tendo apenas as fases de adaptação do inóculo e do carregamento orgânico. Mas o que se observou foi uma falha no reator tratando vinhaça coagulada (reator 2) após 91 dias de operação. Devido a este fato ocorrido, a apresentação do experimento foi divida em duas fases, antes e depois da falha do reator 2, que serão chamadas a partir de agora de Fase I e Fase II, respectivamente.

\subsection{Considerações sobre Caracterização da Vinhaça}

De acordo com a caracterização da vinhaça de cada coleta é possível perceber que as características são similares, indicando que o processo de produção de álcool e açúcar e a qualidade da cana-de-açúcar utilizados ao longo das safras se mantiveram estáveis. Observam-se diferenças significativas entre os valores de Nitrogênio Total Kjeldahl (NTK) e o Nitrogênio Amoniacal, e um ligeiro aumento nas concentrações de cálcio e potássio. Isto provavelmente foi ocasionado pela diferença de aplicação de fertilizantes à base de nitrogênio, potássio e cálcio na lavoura de cana-de-açúcar.

As análises de quantificação DQO e COT demonstram um efluente de alto teor de matéria orgânica. Embasado nestas determinações, optou-se por não aplicar a vinhaça aos reatores na concentração natural, mas sim após diluições. Esta decisão foi tomada a fim assegurar que os reatores não fossem submetidos a um choque capaz de incapacitá-los de exercerem a digestão anaeróbia. 


\subsection{Tratamento Fúsico-Químico - Processo de Coagulação da Vinhaça}

O uso do biopolímero experimental como coagulante da vinhaça resultou nos dados demonstrados na Tabela 5.1.

Tabela 5.1 - Análises físico-químicas da vinhaça bruta e coagulada.

\begin{tabular}{ccccccc}
\hline \multirow{2}{*}{ Parâmetro } & \multicolumn{3}{c}{ Vinhaça Bruta } & \multicolumn{3}{c}{ Vinhaça Coagulada } \\
\cline { 2 - 7 } & Coleta 1 & Coleta 2 & Coleta 3 & Coleta 1 & Coleta 2 & Coleta 3 \\
\hline pH & 4,6 & 4,6 & 4,6 & 12,4 & 12,3 & 12,7 \\
Turbidez (U.T.) & $>6000$ & $>6000$ & $>6000$ & 450 & 890 & 1120 \\
DQO (g/l) & 29,7 & 38,1 & 41,2 & 20,1 & 27,8 & 32,03 \\
Eficiência de remoção & - & - & - & 32,32 & 27,03 & 22,26 \\
de DQO $(\%)$ & - & & & & & \\
\hline
\end{tabular}

Ao analisar os dados obtidos a partir da coagulação da vinhaça, em ambas as coletas, é possível perceber uma redução significativa de turbidez, aumento do $\mathrm{pH}$ de 4,6 para em torno de 12,3 e eficiência de remoção de DQO foi em média 27\%. A Figura 5.1 demonstra antes e depois da aplicação do biopolímero na vinhaça.
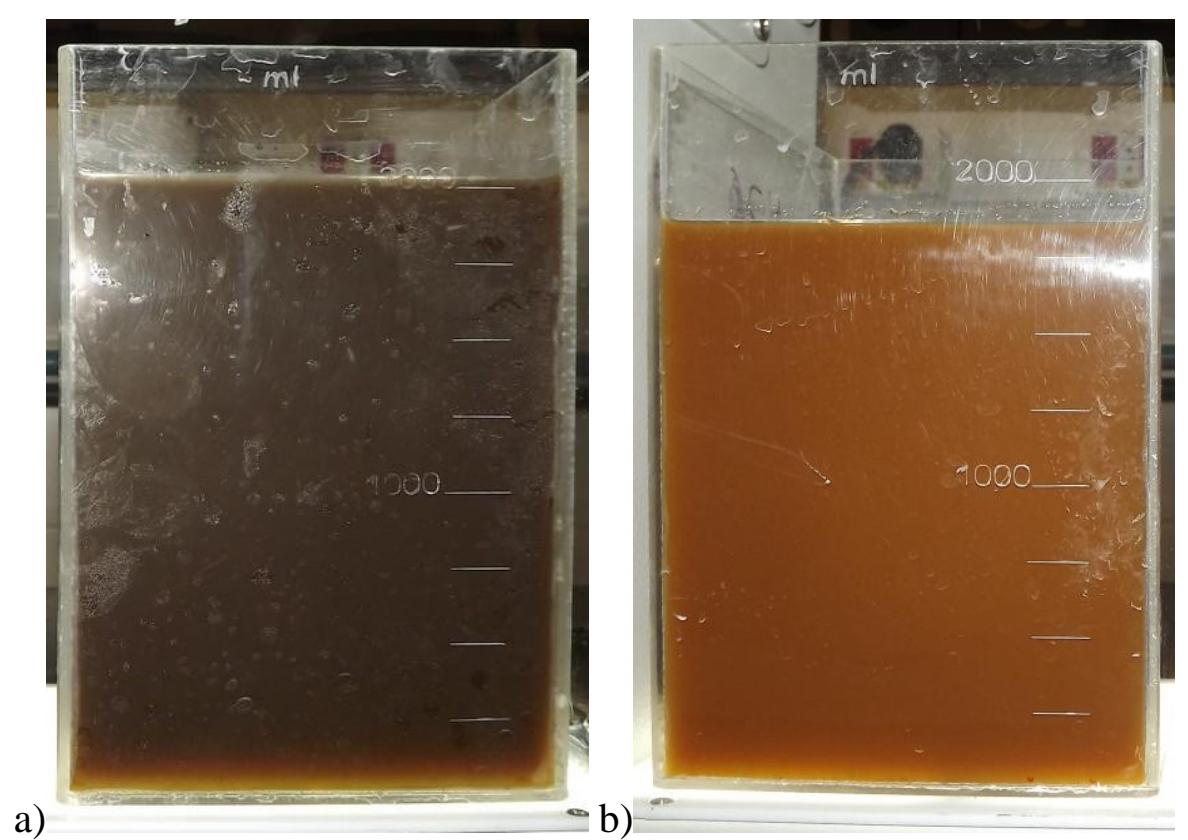

Figura 5.1 - Vinhaça: antes (a) e após (b) tratamento físico-químico.

Este aumento de $\mathrm{pH}$ inviabilizou a vinhaça coagulada de ser aplicada diretamente ao RAHBI, portanto tornou-se necessária a correção do pH. Esta correção alterava o equilíbrio 
químico da solução vinhaça/biopolímero e conferia ao sobrenadante uma cor escura, próxima da cor original da vinhaça (Figuras 5.2a e 5.2b). O pH corrigido durante toda a operação dos reatores variou entre 6,0 e 9,2. Mais detalhes sobre as características da vinhaça aplicada nos reatores serão fornecidas nos itens 5.3.2 e 5.3.3.

Observação:

- Após a correção do pH foram observados dois comportamentos diferentes da vinhaça. Se o galão fosse conservado à temperatura ambiente, a cor voltava a ser amarronzada (Figura 5.2a) após algumas horas. Porém, se o galão fosse conservado em refrigerador à $4^{\circ} \mathrm{C}$ a cor não se alterava e continuava com coloração escura (Figura 5.2b)
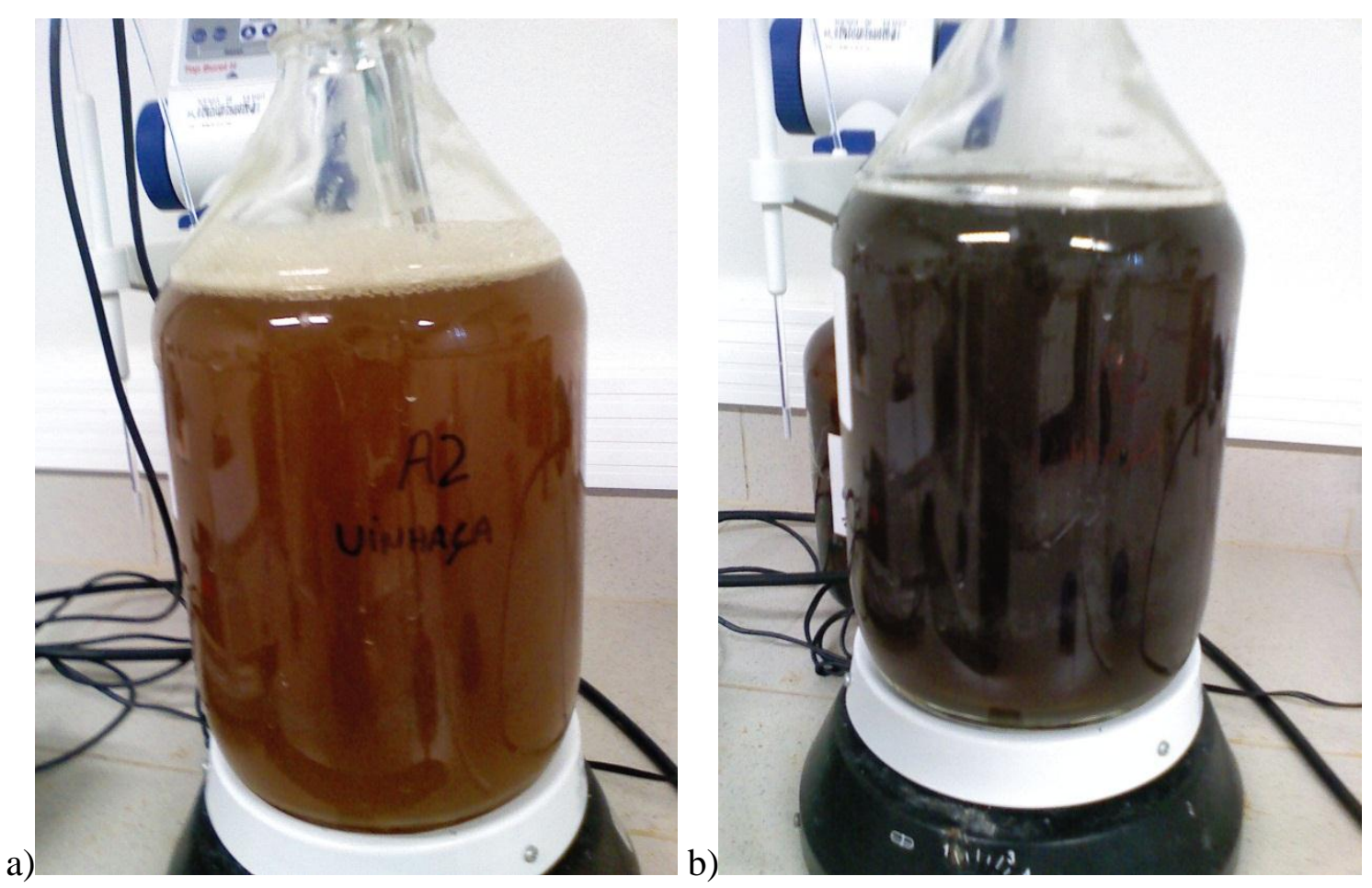

Figura 5.2 - Efeito da correção do pH na vinhaça coagulada. a) pH não corrigido (próximo de 12); b) pH corrigido (próximo de 7).

Detalhes dos resultados do estudo de coagulação/floculação da vinhaça utilizando este biopolímero podem ser encontrados em SAPLA (2012). 


\subsection{Fases do processamento Anaeróbio da Vinhaça}

Neste item são explicitadas as análises das fases da operação com respectivos resultados e desempenhos individuais.

As Tabelas 5.2 e 5.3 apresentam um resumo dos resultados obtidos nas diversas fases do experimento, o detalhamento e análise dos gráficos se fazem a seguir, com a discussão de cada fase do processo. Nestas tabelas podem ser observadas as condições adotadas e seus intervalos, e os resultados obtidos e seus desvios-padrão.

Tabela 5.2 - Características das fases do experimento e as condições adotadas.

\begin{tabular}{|c|c|c|c|c|c|c|c|}
\hline Fase & $\begin{array}{c}\text { Duração } \\
\text { (dias) }\end{array}$ & Reator & DQO $(\mathrm{g} / \mathrm{l})$ & $\begin{array}{c}\text { Adição de } \\
\text { Bicarb. } \\
\left(\mathrm{gHCO}_{3} / \mathrm{gDQO}\right)\end{array}$ & $\begin{array}{c}\text { TDH } \\
\text { (h) }\end{array}$ & $\begin{array}{c}\mathrm{COV}(\mathrm{kg} \\
\left.\mathrm{DQO} / \mathrm{m}^{3} \cdot \mathrm{d}\right)\end{array}$ & Recirc. \\
\hline \multirow{2}{*}{ Adaptação } & \multirow{2}{*}{22} & 1 & $2,8 \pm 1,7$ & 1,0 & \multirow{2}{*}{$\begin{array}{c}35,7 \pm \\
0,2\end{array}$} & $1,9 \pm 1,1$ & Não \\
\hline & & 2 & $3,3 \pm 1,6$ & - & & $2,2 \pm 1,1$ & Não \\
\hline \multirow{2}{*}{ I } & \multirow{2}{*}{69} & 1 & $9,8 \pm 4,4$ & 1,0 & \multirow{2}{*}{$\begin{array}{c}39,5 \pm \\
0,3\end{array}$} & $5,3 \pm 1,3$ & Sim \\
\hline & & 2 & $9,7 \pm 5,6$ & - & & $5,3 \pm 1,6$ & Sim \\
\hline \multirow{2}{*}{ II } & \multirow{2}{*}{37} & 1 & $7,6 \pm 3,6$ & 1,0 & \multirow{2}{*}{$\begin{array}{c}35,7 \pm \\
0,2\end{array}$} & $5,1 \pm 2,4$ & Sim \\
\hline & & 2 & $7,5 \pm 3,4$ & - & & $5,0 \pm 2,3$ & Sim \\
\hline
\end{tabular}

Tabela 5.3 - Resultados das análises dos parâmetros de monitoramento dos efluentes dos reatores 1 e

\begin{tabular}{cccccc}
\hline Fase & Reator & $\mathbf{p H}$ & $\begin{array}{c}\text { Alc. Parcial } \\
(\mathbf{m g C a C O} / \mathbf{l})\end{array}$ & $\begin{array}{c}\text { DQO efluente } \\
(\mathbf{m g} / \mathbf{l})\end{array}$ & $\begin{array}{c}\text { Eficiência de } \\
\text { Remoção DQO } \\
(\%)\end{array}$ \\
\hline \multirow{2}{*}{ Adaptação } & 1 & 8,76 & 813,7 & $419,4 \pm 204,9$ & $88,0 \pm 5,4$ \\
& 2 & 8,75 & 876,1 & $492,6 \pm 421,0$ & $86,4 \pm 8,0$ \\
\hline \multirow{2}{*}{ I } & 1 & $8,75 \pm 0,43$ & $4893,1 \pm 3292,5$ & $1463,3 \pm 541,0$ & $82,9 \pm 4,4$ \\
& 2 & $7,73 \pm 0,16$ & $1139,8 \pm 250,5$ & $2848,7 \pm 2546,2$ & $72,2 \pm 22,8$ \\
\hline \multirow{2}{*}{ II } & 1 & $8,23 \pm 0,44$ & $2432,5 \pm 708,9$ & $1853,7 \pm 1457,7$ & $77,5 \pm 9,4$ \\
& 2 & $7,97 \pm 0,50$ & $1659,0 \pm 297,1$ & $1539,9 \pm 1130,1$ & $79,2 \pm 9,7$ \\
\hline
\end{tabular}

Reator 1 - Controle; Reator 2 - Tratamento.

Observa-se que os desvios-padrão de DQO efluente na fase de adaptação, para os dois reatores, são 419,4 \pm 204,9 e 492,6 \pm 421,0 mg/l, respectivamente. Estes valores 
variaram bastante, pois na fase de adaptação foram empregados valores crescentes de COV no afluente. Estes valores serão discutidos no item 5.3.1.

BROWN (2012) operou um reator UASB processando vinhaça, com recirculação de parte do efluente, com aumento sucessivo da carga orgânica volumétrica que variou de 0,5 a $7,5 \mathrm{~kg} / \mathrm{m}^{3} \mathrm{~d}$. Nestas condições, obteve-se eficiência de remoção de DQO, máxima e mínima, de $97,31 \%\left(\mathrm{COV}=1,03 \mathrm{~kg} / \mathrm{m}^{3} \mathrm{~d}\right)$ e 48,88\% (COV = 7,03 kg/m³ $)$. Em comparação com os dados obtidos durante o período de operação dos dois reatores anaeróbios híbridos, percebe-se que o reator 1, que possuiu configuração similar ao reator de BROWN (2012), apresentou melhor eficiência de remoção durante o período experimental, tendo média de 82,9 $\pm 4,4 \%$ $\left(\mathrm{COV}=5,3 \pm 1,3 \mathrm{~kg} / \mathrm{m}^{3} \mathrm{~d}\right)$ na Fase I e $77,5 \pm 9,4 \%\left(\mathrm{COV}=5,1 \pm 2,4 \mathrm{~kg} / \mathrm{m}^{3} \mathrm{~d}\right)$ na Fase II.

\subsubsection{Adaptação}

A fase de adaptação da biomassa teve duração de 22 dias. Neste período decidiu-se manter uma carga orgânica volumétrica (COV) em torno de $2,5 \mathrm{~kg} / \mathrm{m}^{3} \mathrm{~d}$ e TDH de 36 horas para ambos os reatores. A Figuras 5.3 e 5.4 ilustram a variação da COV e da eficiência de remoção no período de adaptação para os reatores 1 e 2 .

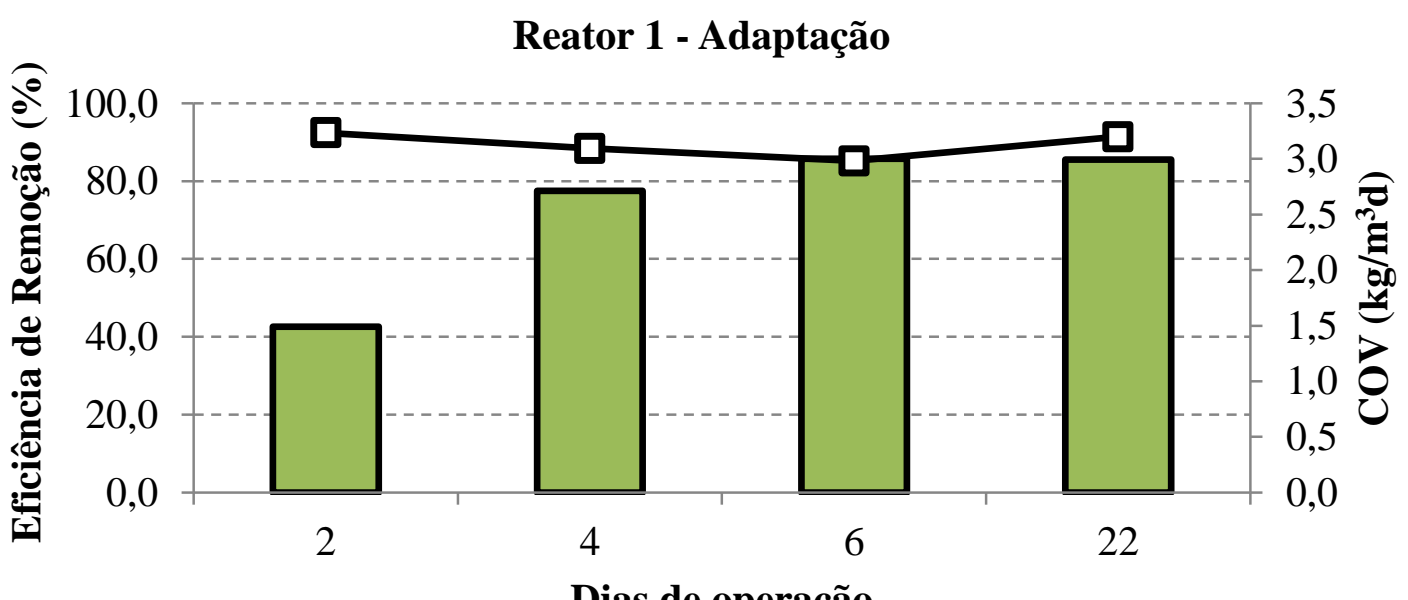

Dias de operação

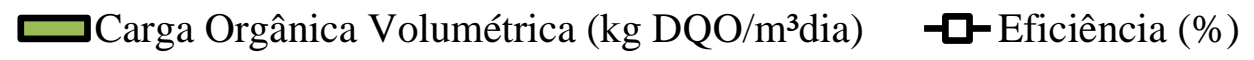

Figura 5.3 - Variação da COV e eficiência de remoção de DQO na fase de adaptação no reator 1. 


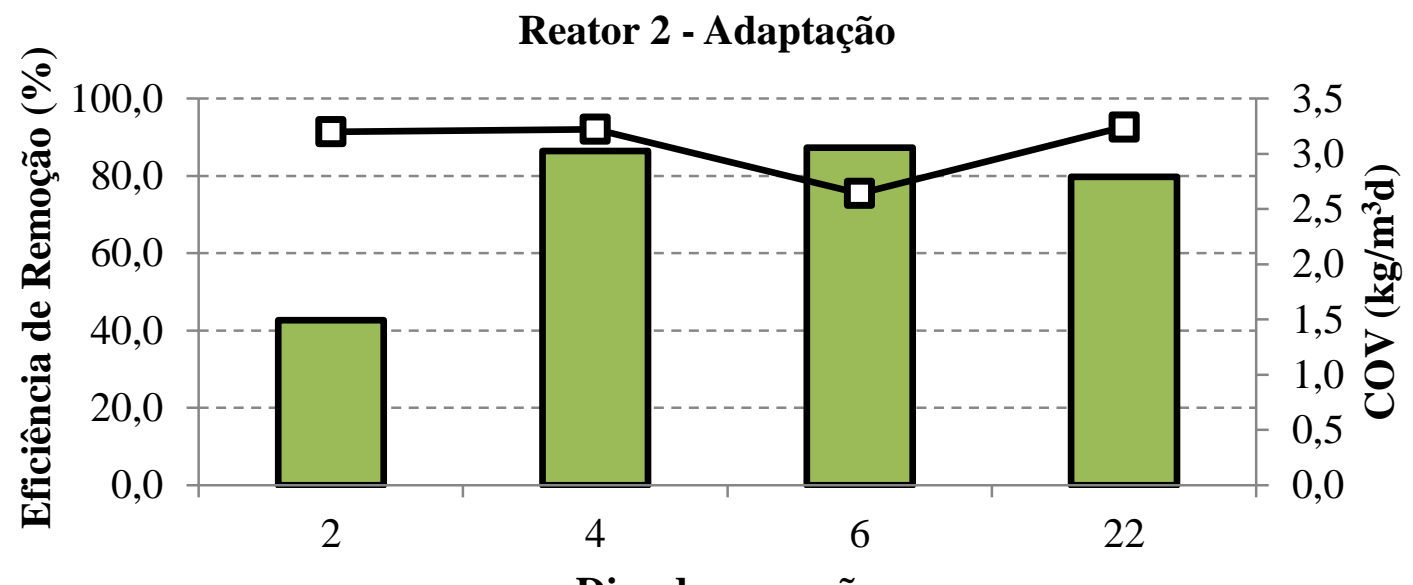

Dias de operação

$\square$ Carga Orgânica Volumétrica (kg DQO/m²dia) - - - Eficiência (\%)

Figura 5.4 - Variação da COV e eficiência de remoção de DQO na fase de adaptação no reator 2 .

No início da operação dos reatores não foram realizadas análises de todos os parâmetros do afluente e efluente, pois a intenção desta etapa foi apenas atingir a estabilidade do processo de processamento para ambos os reatores, indicado pela eficiência de remoção de DQO.

Como pode ser observado nas Figuras 5.3 e 5.4, a eficiência de remoção para ambos os reatores foram similares, ficando em média $88 \%$ para o reator 1 , e $86,4 \%$ para o reator 2 , como demonstrado na Tabela 5.3. A partir de observada a estabilidade do sistema optou-se por aumentar a COV gradativamente até atingir $10 \mathrm{~kg} / \mathrm{m}^{3} . \mathrm{d}$, dando início à Fase I, cujos resultados estão presentes no item 5.3.2.

\subsubsection{Fase I}

A Fase I teve duração de 69 dias e ocorreu após a fase de adaptação. Iniciou-se a operação dos reatores com COV inicial de aproximadamente $4,0 \mathrm{~kg} / \mathrm{m}^{3} \mathrm{~d}$ e TDH de 36 horas. A vazão de recirculação foi 3 vezes maior que a vazão de alimentação.

Esperava-se aplicar COV de $10 \mathrm{~kg} / \mathrm{m}^{3} \mathrm{~d}$, mas ao aplicar aproximadamente $7,0 \mathrm{~kg} / \mathrm{m}^{3} \mathrm{~d}$ durante uma semana, o reator 2 apresentou indícios de um possível colapso. Este foi o marco do fim da Fase I, e este fato é discutido no item 5.3.2.3. 


\subsubsection{Reator 1}

A Figura 5.5 ilustra a variação da $\mathrm{COV}$ afluente em relação à eficiência de remoção de DQO para o reator 1.

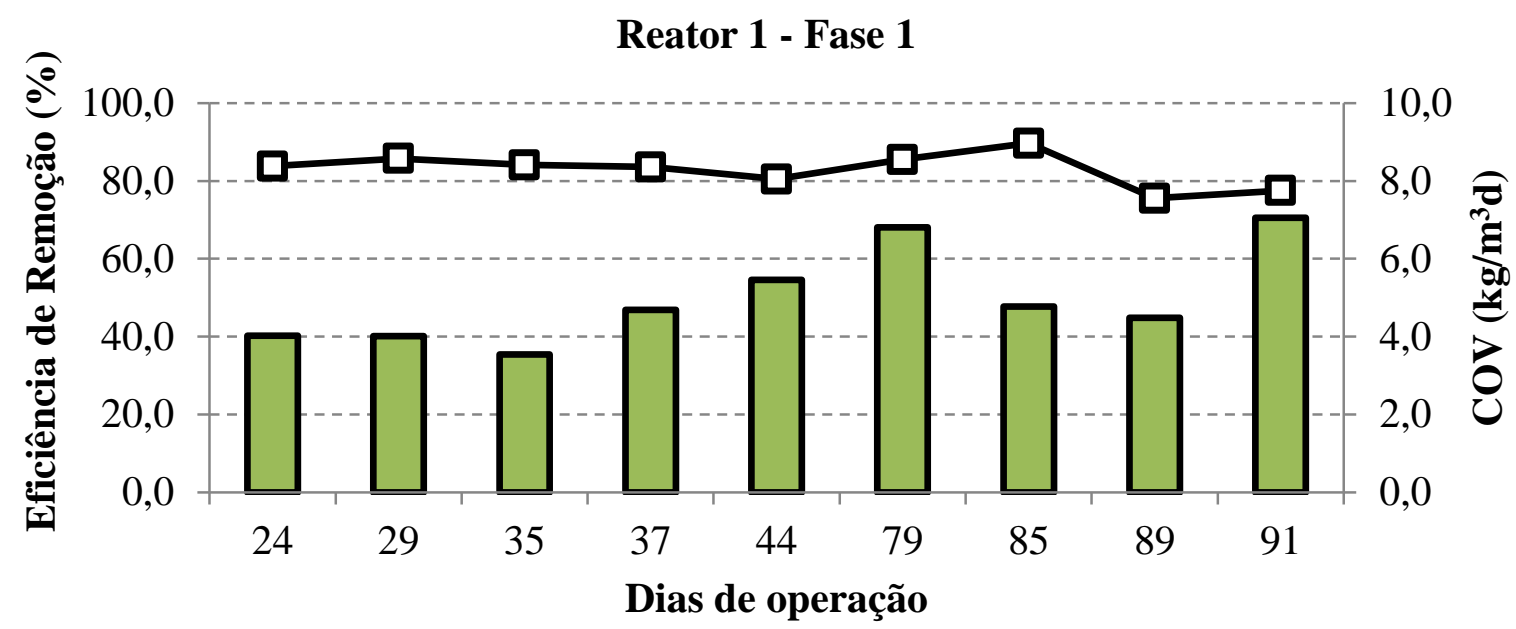

$\square$ Carga Orgânica Volumétrica (kg DQO/m³dia) - - -Eficiência (\%)

Figura 5.5 - Variação da carga orgânica volumétrica (COV) e eficiência do reator 1 durante a Fase I.

A Tabela 5.4 mostra os valores médios de COV, DQO e íon sulfato do afluente e do efluente para esta fase de operação, além da eficiência de remoção de DQO.

Tabela 5.4 - Concentrações de DQO, COV e íon sulfato do afluente e do efluente e eficiência de remoção de DQO para o Reator 1 na Fase I.

\begin{tabular}{lcccc}
\hline \multirow{2}{*}{ Parâmetros } & \multicolumn{2}{c}{ Afluente } & \multicolumn{2}{c}{ Efluente } \\
\cline { 2 - 5 } & Média & Desvio Padrão & Média & Desvio Padrão \\
\hline DQO $(\mathrm{g} / \mathrm{l})$ & 9,8 & 4,4 & 1,5 & 0,5 \\
COV $\left(\mathrm{kg} / \mathrm{m}^{3} . \mathrm{d}\right)$ & 5,3 & 1,3 & 0,7 & 0,3 \\
Sulfato $(\mathrm{mg} / \mathrm{l})$ & 373,0 & - & 74,2 & - \\
\hline
\end{tabular}

Eficiência média de remoção de DQO $82,9 \pm 4,4 \%$

Analisando a Figura 5.5 juntamente com a Tabela 5.4, observa-se que o reator 1 obteve êxito no processamento da vinhaça bruta para cargas orgânicas de até próximo de 7,0 $\mathrm{kg} / \mathrm{m}^{3} \mathrm{~d}$. A eficiência de remoção de DQO foi de $82,9 \pm 4,4 \%$, apresentando uma concentração de DQO no efluente de 1,5 \pm 0,5 g/l. Próximo ao final da Fase I observou-se 
uma queda de quase $10 \%$ da eficiência de remoção de DQO. A Figura 5.6 ilustra os valores de DQO afluente e a sua eficiência de remoção, obtidos durante a Fase I.

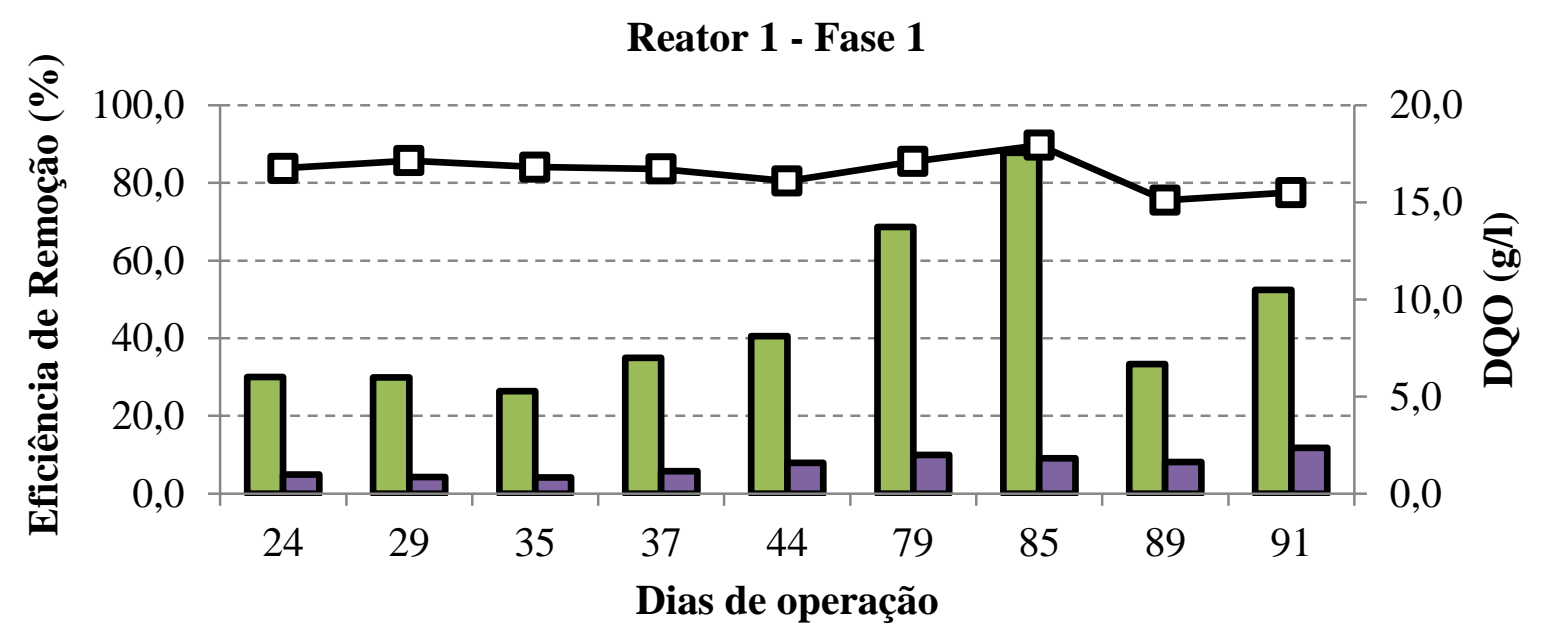

$\square$ DQO Afluente (g/l) $\square$ DQO Efluente (g/l)

Figura 5.6 - Variação da DQO afluente e efluente ao reator 1 durante a Fase I, e sua respectiva eficiência de remoção de DQO.

Nota-se pela Figura 5.6 que o reator 1 permaneceu estável durante a Fase I, como indica a baixa variação da DQO afluente em relação à efluente, juntamente com a estabilidade da eficiência de remoção. Entre o $44^{\circ}$ e o $85^{\circ}$ dia de operação aplicou-se uma DQO acima 10 $\mathrm{g} / \mathrm{l}$, porém também houve uma redução da vazão afluente, de 1,0 para 3,6 1/d. Assim, manteve-se a COV próximo aplicado normalmente $\left(5,0 \mathrm{~kg} \mathrm{DQO} / \mathrm{m}^{3} \mathrm{~d}\right)$.

O sulfato presente no afluente foi de $373,0 \mathrm{mg} / \mathrm{l}$, e no efluente foi de $74,2 \mathrm{mg} / \mathrm{l}$, resultando em uma eficiência de remoção de $80,1 \%$ do sulfato presente na vinhaça.

A Figura 5.7 ilustra os valores de $\mathrm{pH}$ obtidos durante a operação do reator 1 na Fase I. 


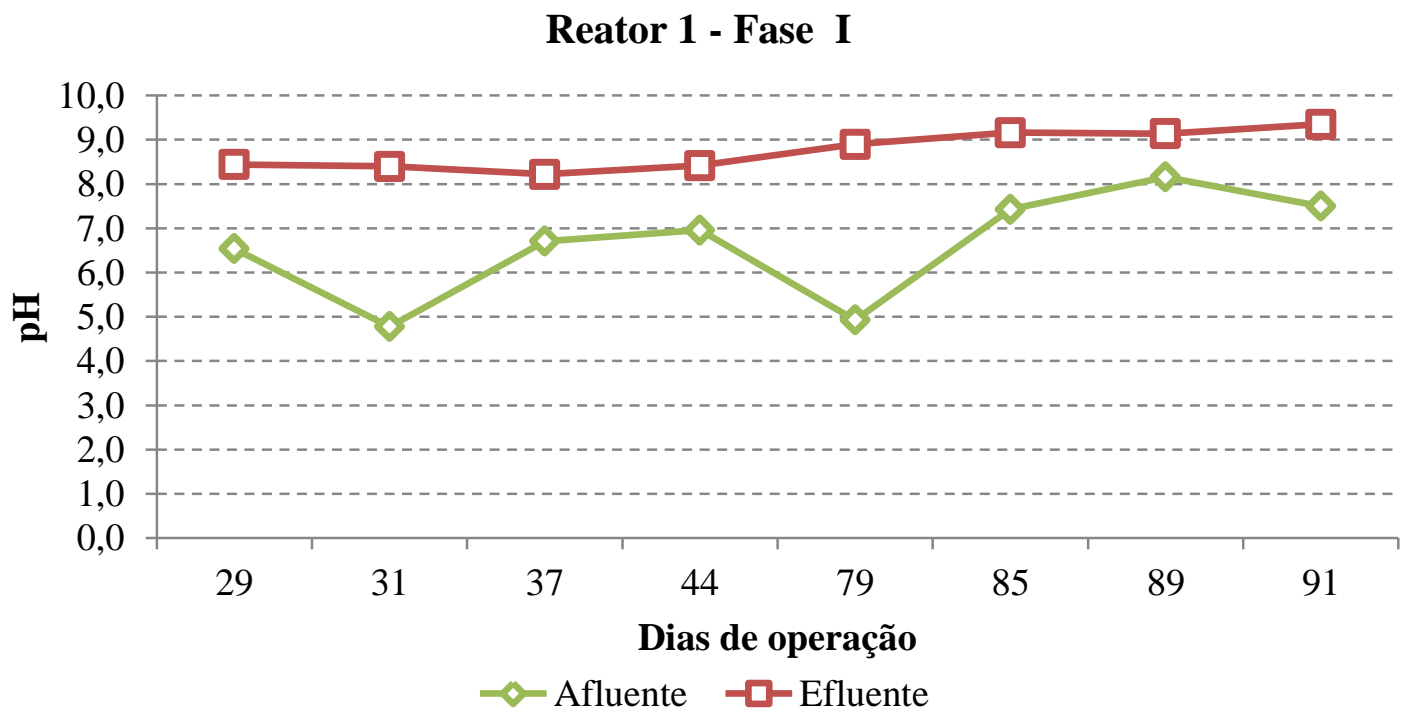

Figura 5.7 - Valores de $\mathrm{pH}$ afluente e efluente ao reator 1 na Fase I.

$\mathrm{O}$ pH no sistema permaneceu dentro de uma faixa de pouca variação, com um valor médio de 6,6 $\pm 1,2$ no afluente e 8,7 \pm 0,4 no efluente. Houve suplementação de bicarbonato de sódio na proporção de gBicarbonato:gDQO 1:1. Mesmo nos dois momentos em que o pH do afluente esteve próximo de 5,0, não houve influência no $\mathrm{pH}$ efluente, indicando estabilidade do sistema. Estes valores estão na faixa ótima de desenvolvimento dos microrganismos heterotróficos anaeróbios (POSTGATE, 1984).

O comportamento da alcalinidade total durante a Fase I do Reator 1 pode ser visualizado na Figura 5.8.

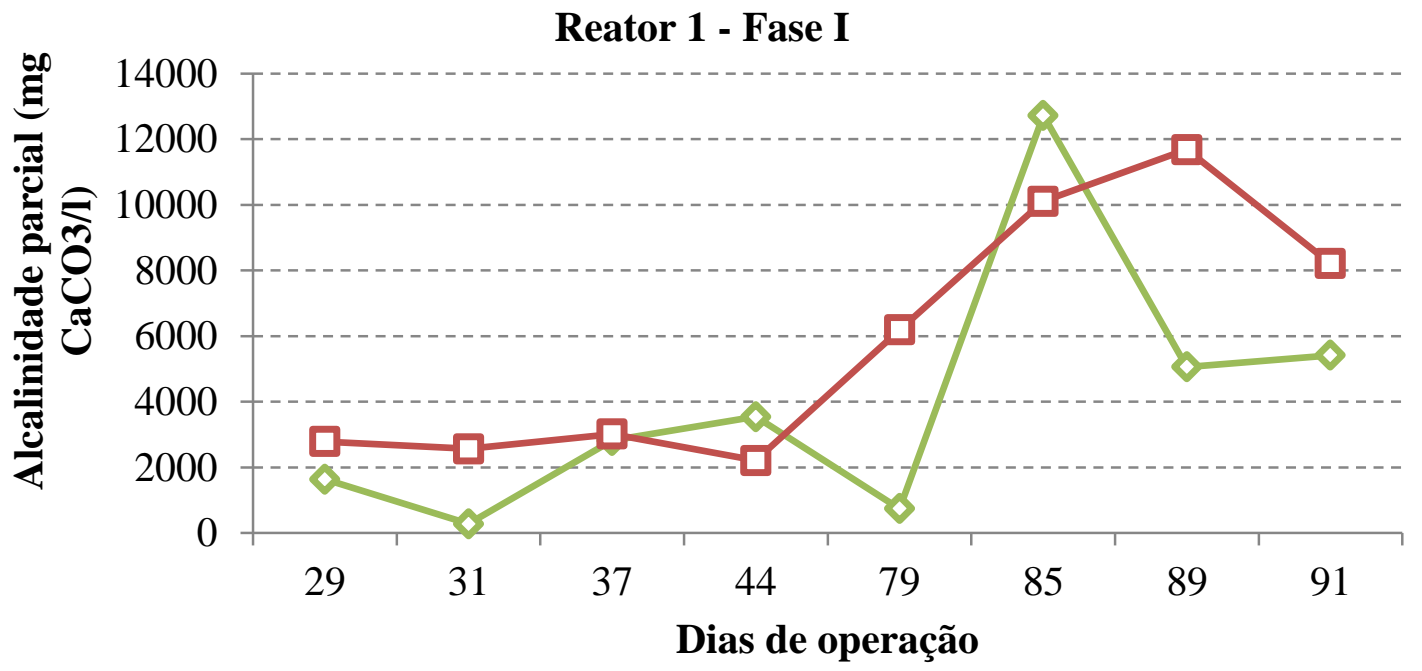

$\checkmark-$ Afluente $-\square$-Efluente

Figura 5.8 - Variação da alcalinidade total do afluente e do efluente do reator 1 durante a Fase 
Com relação à alcalinidade, não houve um comportamento fixo no afluente, sendo que este parâmetro variou desde valores tão baixos quanto $278,9 \mathrm{mg} \mathrm{CaCO}_{3} / 1$, quanto valores de até $12727,4 \mathrm{mg} \mathrm{CaCO}_{3} / 1$. Este aumento súbito na concentração de alcalinidade total pode ser justificado pelo aumento de TDH entre os $44^{\circ}$ e o $85^{\circ}$ dias de operação, chegando a 3,6 dias, como explicado anteriormente. Entretanto, a alcalinidade total do efluente sempre esteve com valores acima de $2000 \mathrm{mg} \mathrm{CaCO}_{3} / 1$, permanecendo estável durante 42 dias de operação, e após esta data há um aumento significativo, chegando a 11682,5 mg $\mathrm{CaCO}_{3} / 1$. Este aumento está ligado à tentativa de manutenção da $\mathrm{COV}$ próximo de $5,0 \mathrm{~kg} \mathrm{DQO} / \mathrm{m}^{3} \mathrm{~d}$ durante o aumento do TDH. Desta forma, para manter esta COV, foi necessário aumentar a concentração de DQO afluente, ocasionando, também, um aumento da quantidade de bicarbonato de cálcio adicionada ao reator 1 . Obedecendo a relação $1 \mathrm{~g}$ bicarbonato:1g DQO (SPEECE, 1996), foi adicionado 13,7g de bicarbonato ao afluente, pois foram aplicados 13,7 g DQO/l ao afluente.

Os valores médios de alcalinidade total para o afluente e efluente foram de 4027,0 \pm 3981,4 e 5845,3 $\pm 3766,9 \mathrm{mgCaCO}_{3} / 1$, respectivamente. A variação provavelmente se dá pelo fato de a vinhaça ser muito complexa e estar em constante atividade, mesmo armazenado em baixas temperaturas, como é o caso da vinhaça utilizada neste experimento.

De acordo com METCALF e EDDY (2003), para o bom desempenho de um sistema anaeróbio, a alcalinidade total deve ser mantida entre 1000,0 e 5000,0 $\mathrm{mgCaCO}_{3} / \mathrm{l}$, dada a possibilidade de acidificação do sistema. Contudo, estes valores são válidos para sistemas de tratamento anaeróbio para esgoto sanitário. Entretanto, é comum realizar esta analogia de valores a serem baseados para sistemas processando efluentes industriais (PEREIRARAMIREZ, et al., 2004; DIAS, et al., 2008).

Portanto, a adição de álcali ao reator 1 foi suficiente para manter o $\mathrm{pH}$ do reator $1 \mathrm{em}$ uma faixa favorável para a digestão anaeróbia.

\subsubsection{Reator 2}

A Figura 5.9 ilustra a variação da COV afluente em relação à eficiência de remoção de DQO para o reator 2. 


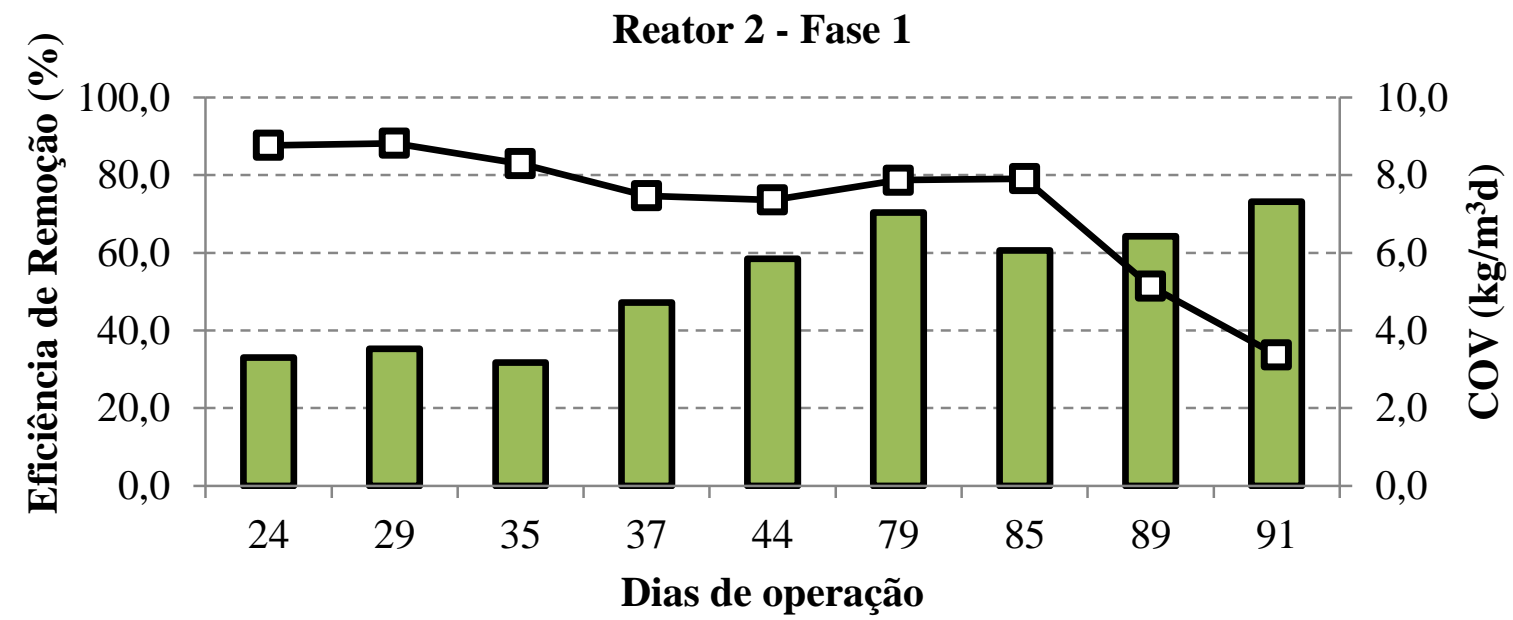

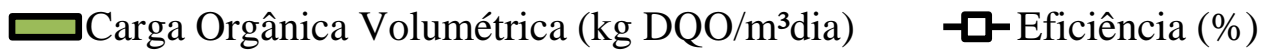

Figura 5.9 - Variação da carga orgânica volumétrica (COV) e eficiência do reator 2 durante a Fase I.

A Tabela 5.5 mostra os valores médios de COV, DQO e íon sulfato do afluente e do efluente para esta fase de operação, além da eficiência de remoção de DQO.

Tabela 5.5 - Concentrações de DQO, COV e íon sulfato do afluente e do efluente e eficiência de remoção de DQO para o reator 2 na Fase I.

\begin{tabular}{lcccc}
\hline \multirow{2}{*}{ Parâmetros } & \multicolumn{2}{c}{ Afluente } & \multicolumn{2}{c}{ Efluente } \\
\cline { 2 - 5 } & Média & Desvio Padrão & Média & Desvio Padrão \\
\hline DQO $(\mathrm{g} / \mathrm{l})$ & 9,7 & 5,6 & 2,8 & 2,3 \\
COV $\left(\mathrm{kg} / \mathrm{m}^{3} . \mathrm{d}\right)$ & 5,3 & 1,6 & 1,6 & 1,5 \\
Sulfato $(\mathrm{mg} / \mathrm{l})$ & 542,3 & - & $\mathrm{ND}$ & - \\
\hline
\end{tabular}

Eficiência média de remoção de DQO 72,2 \pm 18,1\%

A eficiência de remoção de DQO para a Fase I foi de 72,2 $\pm 18,1 \%$, apresentando uma concentração de DQO no efluente de 2,8 $\pm 2,3 \mathrm{~g} / \mathrm{l}$.

Analisando a Figura 5.9, observa-se que o reator 2 obteve êxito no processamento da vinhaça pré-tratada durante aproximadamente 2 meses de operação $\left(21^{\circ}\right.$ ao $85^{\circ}$ dia $)$, resultando em uma eficiência média de remoção, para estes 2 meses, de 80,7 $\pm 5,8 \%$. Entretanto, a partir deste período o reator 2 apresentou quedas sucessivas em sua eficiência de remoção, chegando à 33,7\%, indicando colapso do sistema.

A Figura 5.10 ilustra os valores de DQO afluente e a sua eficiência de remoção, obtidos durante a Fase I. 


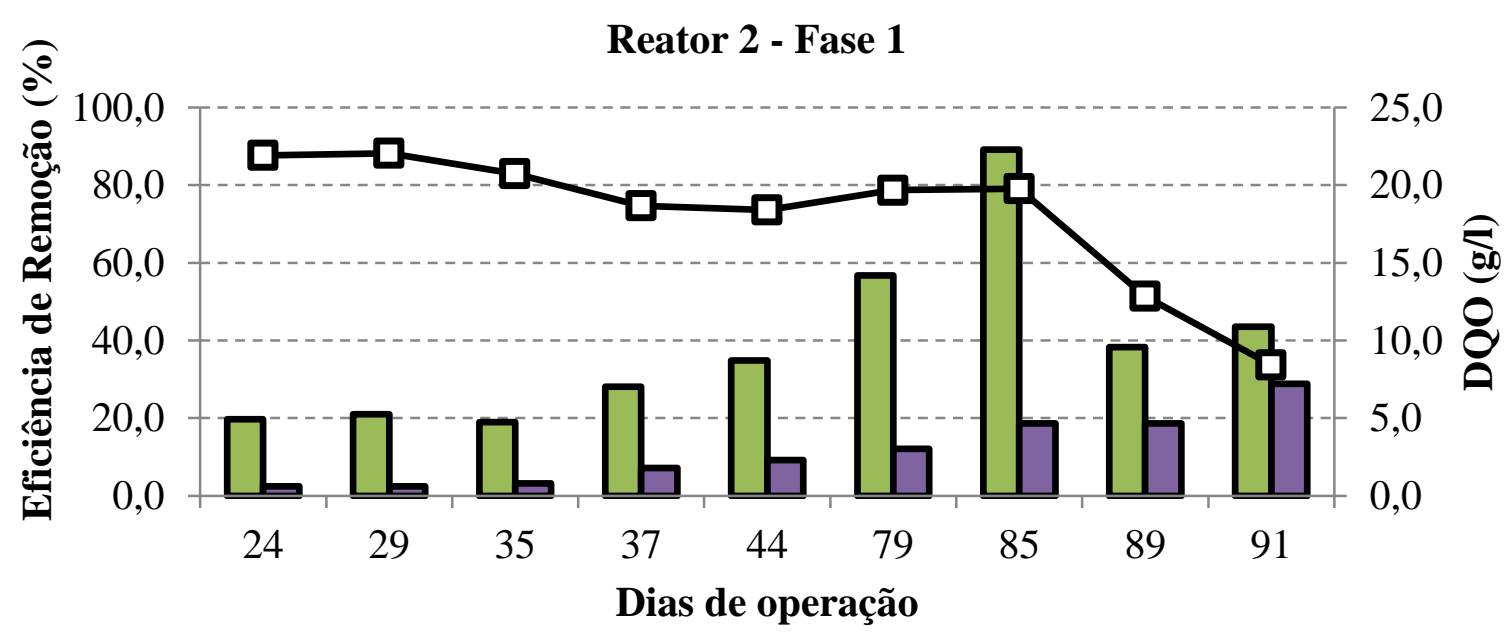

己DQO Afluente (g/l) $\square$ DQO Efluente (g/l)

Figura 5.10 - Variação da DQO afluente e efluente ao reator 2 durante a Fase I, e sua respectiva eficiência de remoção de DQO.

Nota-se pela Figura 5.10 que o reator 2 permaneceu estável até $85^{\circ}$ dia de operação, como indica a baixa variação da DQO afluente em relação à efluente, juntamente com a estabilidade da eficiência de remoção até esta data.

A partir do $85^{\circ}$ dia observou-se uma queda acentuada da eficiência de remoção, indicando colapso do reator 2 .

O sulfato presente no afluente foi de $542,3 \mathrm{mg} / \mathrm{l}$, e no efluente não foi detectado, resultando em uma eficiência de remoção de $100 \%$ do sulfato presente na vinhaça prétratada.

O Figura 5.11 ilustra os valores de pH durante a operação do reator 2 na Fase I.

Reator 2 - Fase I

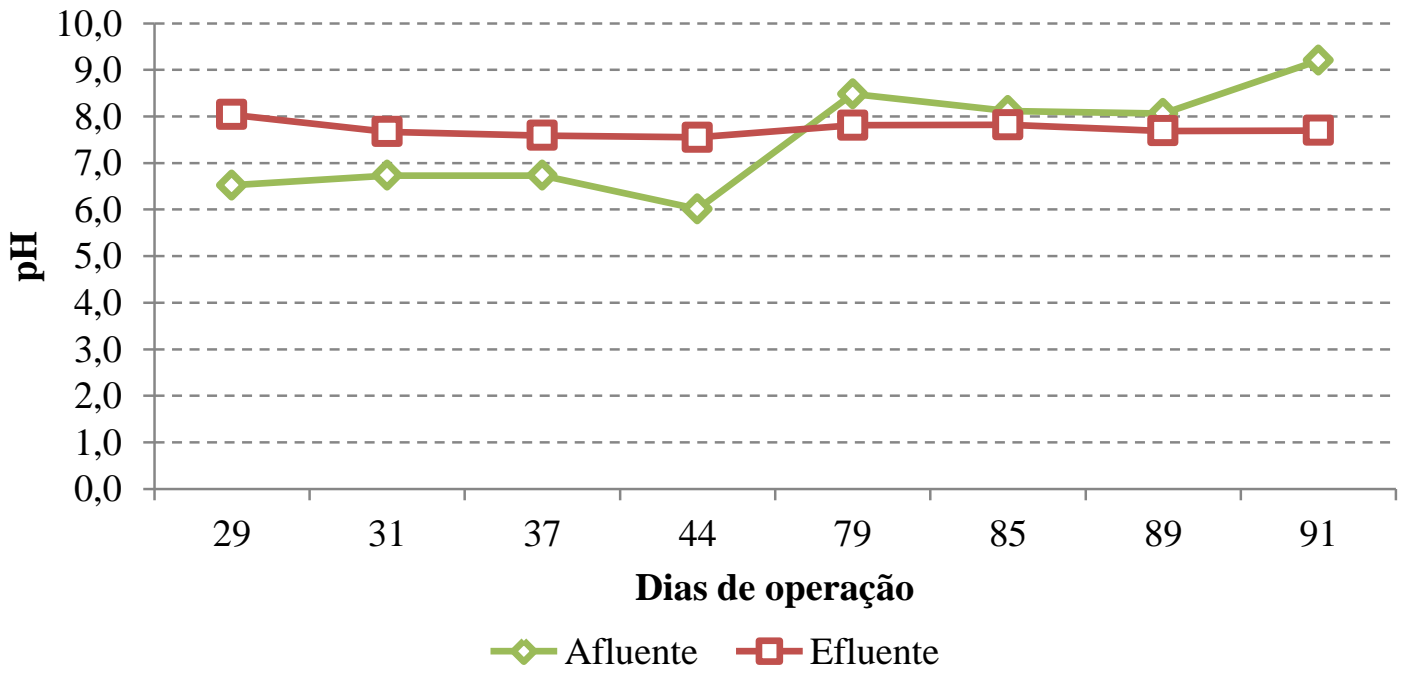

Figura 5.11 - Valores de $\mathrm{pH}$ afluente e efluente ao reator 2 na Fase I. 
$\mathrm{O}$ pH no sistema permaneceu dentro de uma faixa de pouca variação, com um valor médio de 7,5 $\pm 1,1$ no afluente e 7,7 \pm 0,2 no efluente. Não houve suplementação de bicarbonato de sódio em todo o período de operação, pois o biopolímero experimental possui característica alcalina. A partir do $77^{\circ}$ dia de operação o afluente apresentou um pH maior do que a média anterior $\left(22^{\circ}\right.$ ao $44^{\circ}$ dia), que era de $6,5 \pm 0,3$. A média a partir desta data até o fim da Fase I o pH do afluente foi de 8,5 \pm 0,5. A explicação para tal fato é simples. Como era necessário sempre corrigir o $\mathrm{pH}$ da vinhaça pré-tratada para aplicar ao reator 2, optou-se por deixar o $\mathrm{pH}$ do afluente ligeiramente maior e observar os efeitos no efluente. Como se pode constatar pela Figura 5.11, não houve alteração significativa no $\mathrm{pH}$ do efluente, $\operatorname{logo} \mathrm{o} \mathrm{pH}$ do afluente não interferiu no desempenho do reator 2. Sendo assim, pode-se afirmar que a queda de eficiência do reator 2 não foi influenciada pela variação deste parâmetro, pois os valores de pH estão na faixa ótima de desenvolvimento dos microrganismos heterotróficos anaeróbios (POSTGATE, 1984).

O comportamento da alcalinidade total durante a Fase I do Reator 2 pode ser visualizado na Figura 5.12.

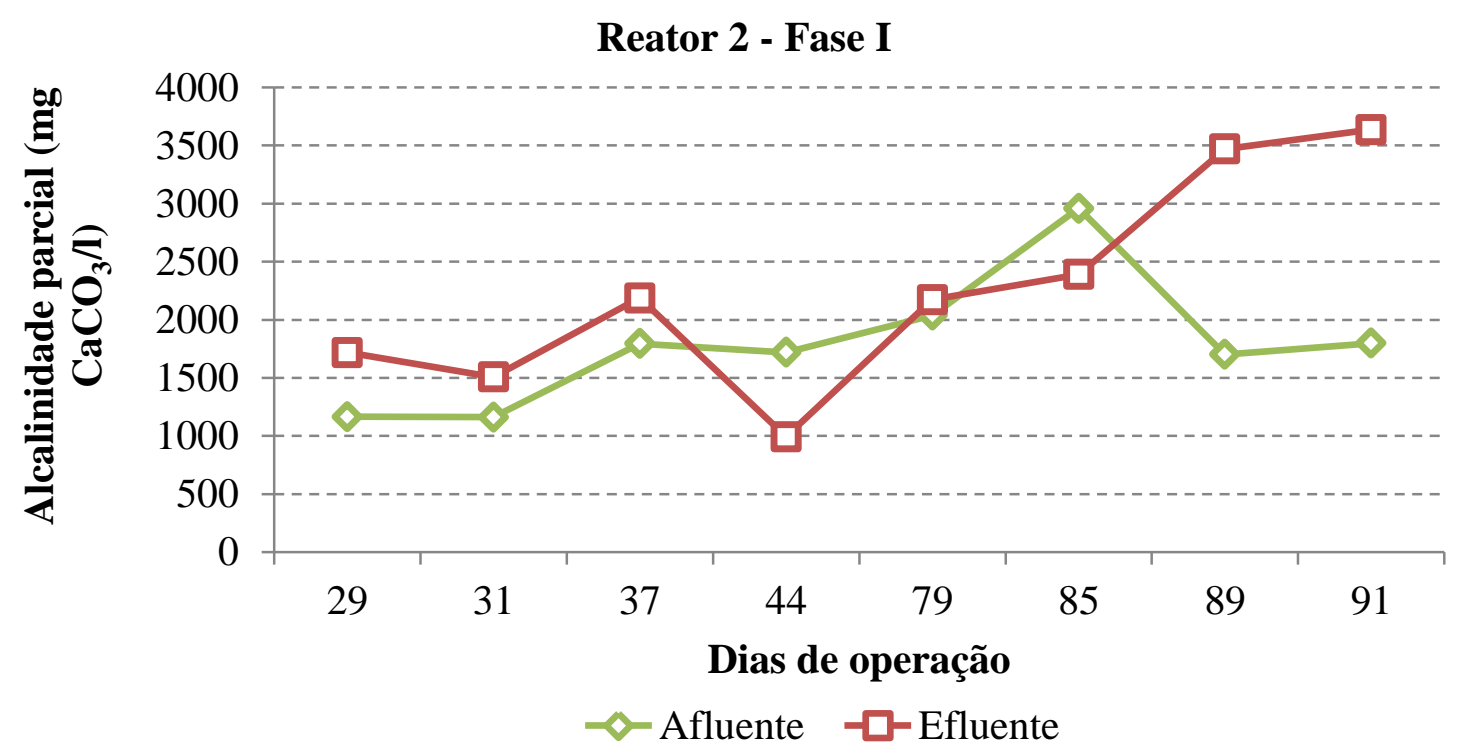

Figura 5.12 - Variação da alcalinidade total do afluente e do efluente do reator 2 durante a Fase I.

Os valores médios de alcalinidade total para o afluente e efluente foram de 1792,8 \pm 563,7 e 2260,3 $\pm 914,7 \mathrm{mg} \mathrm{CaCO}_{3} / 1$, respectivamente.

A alcalinidade fornecida pelo biopolímero no processo de coagulação foi adequada para a manutenção do processo de digestão anaeróbia. Houve um comportamento mais estável do afluente neste reator, comparado ao reator 1. Isto se deve à necessidade de correção do pH 
da vinhaça pré-tratada, conferindo assim um maior controle no $\mathrm{pH}$ do afluente. De acordo com o citado anteriormente, a alcalinidade total manteve-se na faixa recomendada por METCALF e EDDY (1991).

\subsubsection{Falha e Recuperação do Sistema}

Durante todo o monitoramento dos reatores buscou-se observar o comportamento dos reatores em relação à produção de metano e eficiência de remoção de DQO. Após 91 dias de processamento da vinhaça pré-tratada, o reator 2 apresentou uma queda brusca na eficiência de remoção de DQO, indicando um possível colapso. Optou-se, então, por tentar recuperar o sistema para continuar com o processo de processamento. Foram reduzidas as cargas orgânicas volumétricas de entrada para ambos os reatores, além de se utilizar apenas vinhaça bruta para os reatores 1 e 2 . Esta decisão foi baseada no fato de que apenas o reator 2 apresentou falha, indicando que a causa disto estava relacionada com a presença do biopolímero experimental no afluente ao reator 2. O processo foi normalizado após 29 dias de "lavagem" dos reatores, aplicando normalmente a vinhaça no reator 1 e a pré-tratada no reator 2.

\subsubsection{Fase II}

O processo de operação dos reatores 1 e 2 durante a Fase II foi idêntico à Fase I, assim, os parâmetros serão analisados de forma análoga aos itens 5.3.2.1 e 5.3.2.2, referentes aos reatores 1 e 2, respectivamente. Após um processo de readaptação, iniciou-se a operação dos reatores com COV inicial de aproximadamente $1,5 \mathrm{~kg} / \mathrm{m}^{3} \mathrm{~d}$ e TDH de 36 horas e a Fase II teve duração de 37 dias. A vazão de recirculação manteve-se a proporção de 3:1, três vezes maior que a vazão de alimentação.

A carga orgânica volumétrica média obtida nesta fase foi de $5,1 \pm 2,4 \mathrm{~kg} \mathrm{DQO} / \mathrm{m}^{3} \mathrm{~d}$ para o reator 1 , e $5,0 \pm 2,3 \mathrm{~kg} \mathrm{DQO} / \mathrm{m}^{3} \mathrm{~d}$. As COV máximas obtidas foram 8,6 e 7,2 $\mathrm{kg}$ $\mathrm{DQO} / \mathrm{m}^{3} \mathrm{~d}$ para os reatores $1 \mathrm{e} 2$, respectivamente (Figuras 5.13 e 5.16). 
A fim de se manter as mesmas características de operação para ambos os reatores, aplicaram-se as mesmas condições em ambos os reatores, mesmo tendo o reator 1 apresentado comportamento normal, em termos de eficiência de remoção de DQO.

Depois de decorridos os 37 dias de operação, observou-se uma tendência a uma nova falha no reator 2, portanto optou-se por uma interrupção do experimento.

\subsubsection{Reator 1}

A Figura 5.13 ilustra a variação da COV afluente em relação à eficiência de remoção de DQO para o reator 1.

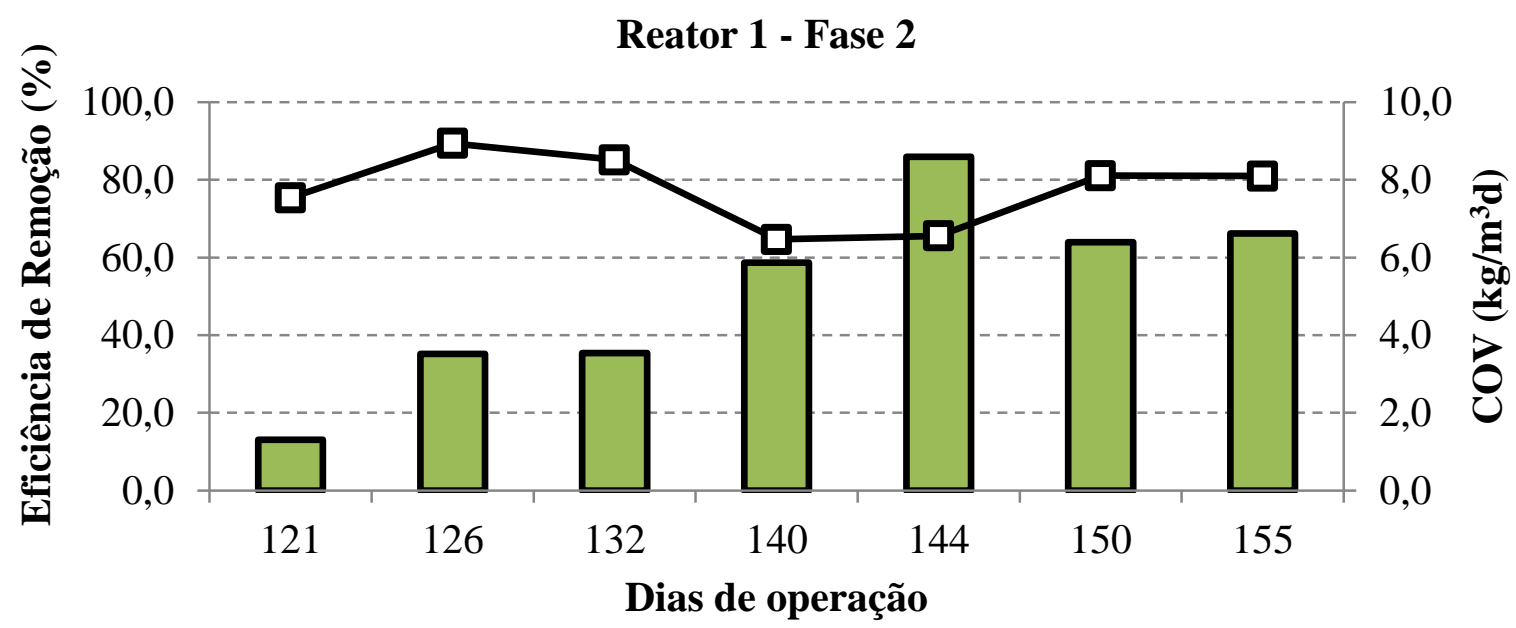

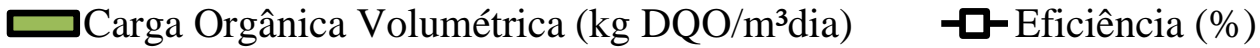

Figura 5.13 - Variação da carga orgânica volumétrica (COV) e eficiência do reator 1 durante a Fase II.

Procurou-se manter a carga em torno de $7 \mathrm{~kg} \mathrm{DQO} / \mathrm{m}^{3} \mathrm{~d}$, mas ao $144^{\circ}$ dia de operação aplicou-se uma $\mathrm{COV}$ de $8,6 \mathrm{~kg} \mathrm{DQO} / \mathrm{m}^{3} \mathrm{~d}$. Isto ocorreu, pois a vinhaça aplicada foi proveniente da terceira coleta, onde a DQO da vinhaça bruta era em torno de $40 \mathrm{~g} / \mathrm{l}$. Logo, a diluição para esta data foi menor do que esperada. Entretanto, após esta aplicação diminuiu-se a carga orgânica para $6,4 \mathrm{~kg} \mathrm{DQO} / \mathrm{m}^{3} \mathrm{~d}$.

A Tabela 5.6 mostra os valores médios de COV, DQO e íon sulfato do afluente e do efluente para esta fase de operação, além da eficiência de remoção de DQO. 
Tabela 5.6 - Concentrações de DQO, COV e íon sulfato do afluente e do efluente e eficiência de remoção de DQO para o Reator 1 na Fase II.

\begin{tabular}{lcccc}
\hline \multirow{2}{*}{ Parâmetros } & \multicolumn{2}{c}{ Afluente } & \multicolumn{2}{c}{ Efluente } \\
\cline { 2 - 5 } & Média & Desvio Padrão & Média & Desvio Padrão \\
\hline DQO $(\mathrm{g} / \mathrm{l})$ & 7,6 & 3,6 & 1,8 & 1,5 \\
COV $\left(\mathrm{kg} / \mathrm{m}^{3} . \mathrm{d}\right)$ & 5,1 & 2,4 & 1,2 & 1,0 \\
Sulfato $(\mathrm{mg} / \mathrm{l})$ & 611,7 & 1,5 & 104,6 & 3,1 \\
\hline
\end{tabular}

Eficiência média de remoção de DQO 77,5 \pm 9,4\%

Ao analisar a Figura 5.13 juntamente com a Tabela 5.6, observa-se que o reator 1 novamente obteve êxito no processamento da vinhaça bruta para cargas orgânicas de até próximo de $7 \mathrm{~kg} / \mathrm{m}^{3}$.d. A eficiência de remoção de DQO foi de 77,5 \pm 9,4\%, apresentando uma concentração de DQO no efluente de 1,8 \pm 1,4 g/l. Próximo ao final da Fase II observouse uma queda de quase 20 pontos percentuais da eficiência de remoção de DQO, de $85 \%$ para $65 \%$ de eficiência de remoção, e uma subsequente estabilização em torno de $80 \%$.

De forma análoga à Fase I, o reator 1 apresentou boa estabilidade na remoção de matéria orgânica, e os valores de DQO afluente e efluente foram relativamente estáveis, como indica a Figura 5.14.

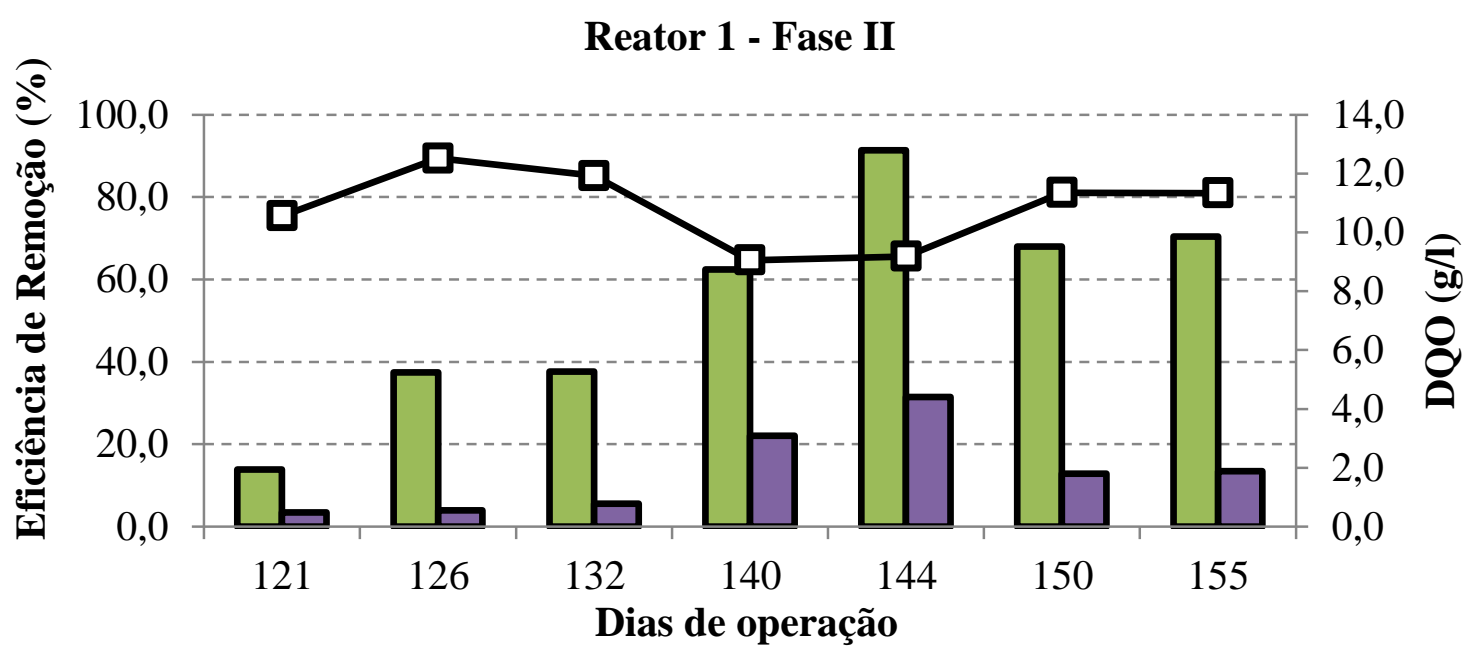

صDQO Afluente (g/l) صDO Efluente (g/l)

Figura 5.14 - Variação da DQO afluente e efluente ao reator 1 durante a Fase II, e sua respectiva eficiência de remoção de DQO.

O sulfato presente no afluente foi de $611,7 \pm 1,5 \mathrm{mg} / \mathrm{l}$, e no efluente foi de 104,6 \pm $3,1 \mathrm{mg} / 1$, resultando em uma eficiência de remoção de $82,9 \pm 0,4 \%$ do sulfato presente na vinhaça. 
O Figura 5.15 ilustra os valores de pH obtidos durante a operação do reator 1 na Fase II.

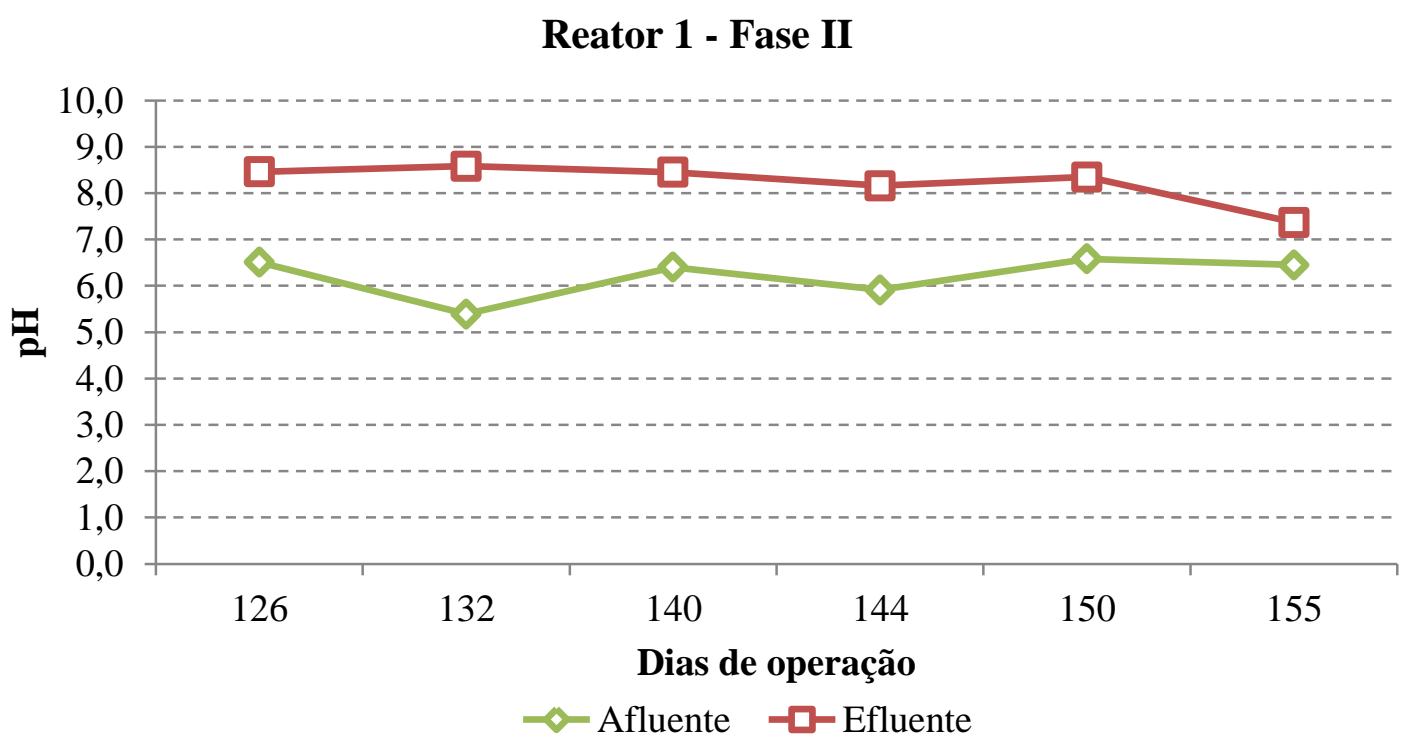

Figura 5.15 - Valores de $\mathrm{pH}$ afluente e efluente ao reator 1 na Fase II.

$\mathrm{O}$ pH no sistema nesta fase, como observado na Figura 5.14, apresentou pouca variação, com um valor médio de 6,2 $\pm 0,5$ no afluente e $8,2 \pm 0,4$ no efluente. Houve suplementação do afluente com bicarbonato de sódio na proporção de gBicarbonato:gDQO 1:1,em todo o período. Estes valores estão na faixa ótima de desenvolvimento dos microrganismos heterotróficos anaeróbios (POSTGATE, 1984).

O comportamento da alcalinidade total durante a Fase II do reator 1 pode ser visualizado na Figura 5.16.

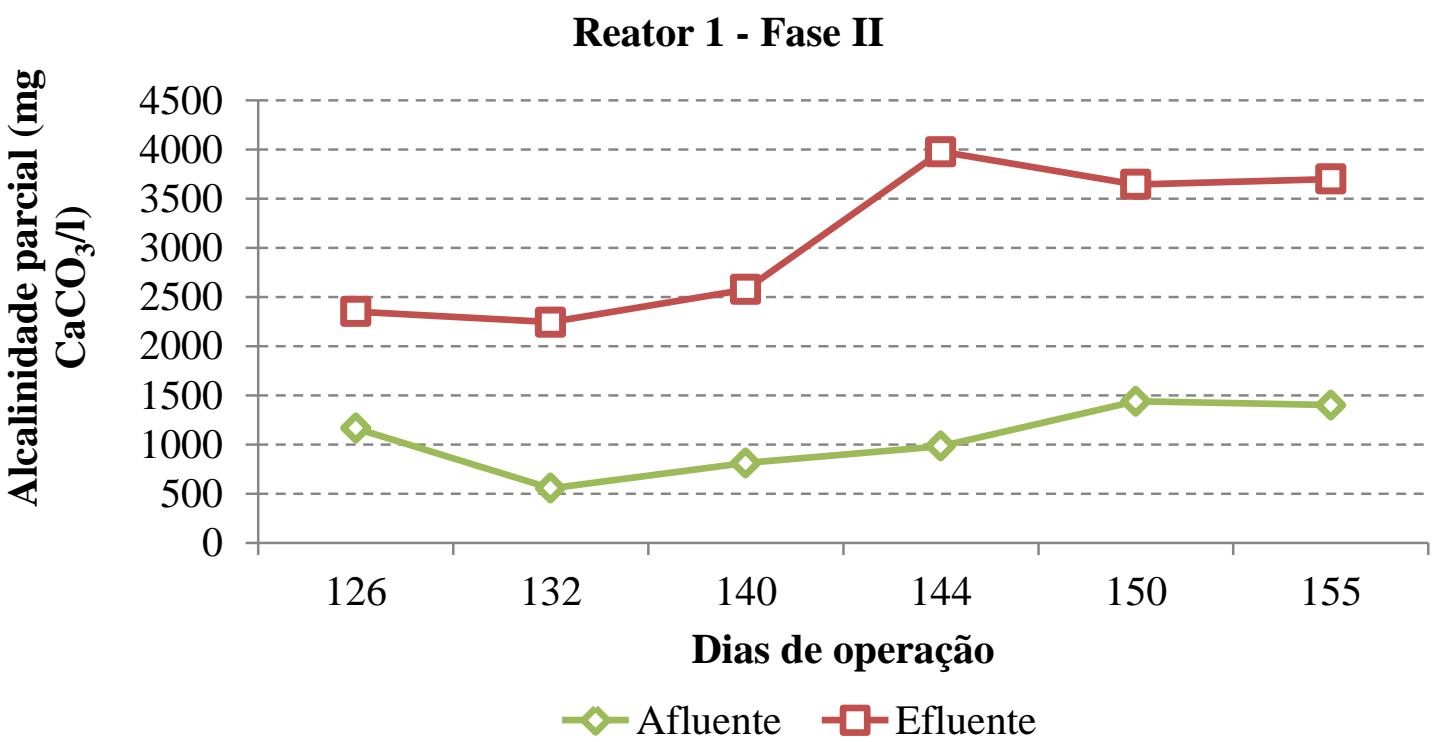

Figura 5.16 - Variação da alcalinidade total do afluente e do efluente do reator 1 durante a Fase II. 
Ao contrário do observado na Fase I, a alcalinidade do afluente manteve-se estável durante todo o período da Fase II, com uma média de 1058,4 $\pm 342,9 \mathrm{mg} \mathrm{CaCO}_{3} / \mathrm{l}$. A alcalinidade total do efluente manteve valores acima de $2000 \mathrm{mg} \mathrm{CaCO}_{3} / \mathrm{l}$, apresentando média de 3082,0 $\pm 772,8 \mathrm{mg} \mathrm{CaCO} 3 / 1$, suficiente para garantir a estabilidade do sistema.

Durante toda a Fase II, como pôde-se perceber nos resultados deste item, o reator 1 apresentou estabilidade e alto desempenho na remoção de DQO, e não apresentou indícios de falha.

\subsubsection{Reator 2}

A Figura 5.17 ilustra a variação da COV afluente em relação à eficiência de remoção de DQO para o Reator 2.

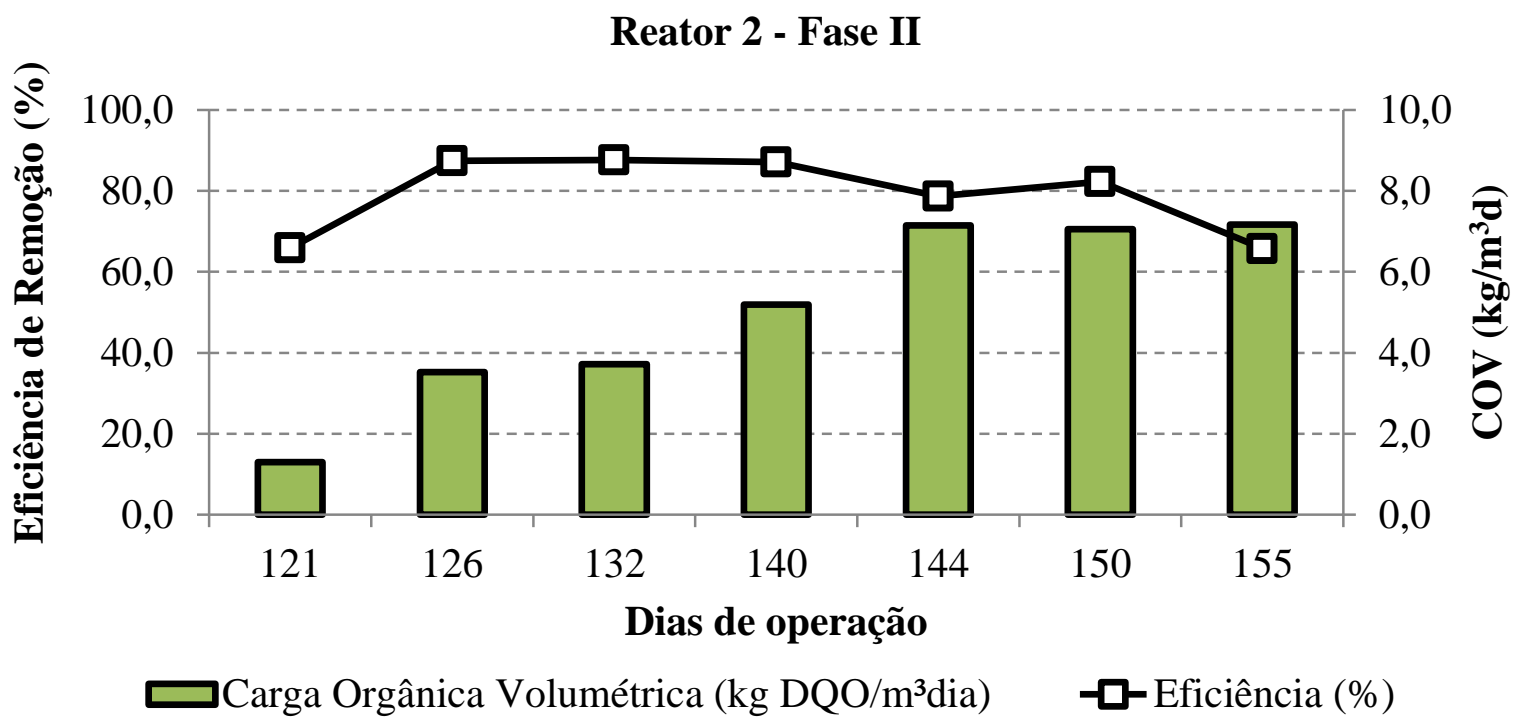

Figura 5.17 - Variação da carga orgânica volumétrica (COV) e eficiência do reator 2 durante a Fase II.

A Tabela 5.7 mostra os valores médios de COV, DQO e íon sulfato do afluente e do efluente para esta fase de operação, além da eficiência de remoção de DQO. 
Tabela 5.7 - Concentrações de DQO, COV e íon sulfato do afluente e do efluente e eficiência de remoção de DQO para o reator 2 na Fase II.

\begin{tabular}{lcccc}
\hline \multirow{2}{*}{ Parâmetros } & \multicolumn{2}{c}{ Afluente } & \multicolumn{2}{c}{ Efluente } \\
\cline { 2 - 5 } & Média & Desvio Padrão & Média & Desvio Padrão \\
\hline DQO $(\mathrm{g} / \mathrm{l})$ & 7,5 & 3,4 & 1,5 & 1,1 \\
COV $\left(\mathrm{kg} / \mathrm{m}^{3} . \mathrm{d}\right)$ & 5,0 & 2,3 & 1,0 & 0,8 \\
Sulfato $(\mathrm{mg} / \mathrm{l})$ & 814,6 & 8,5 & 204,7 & 4,2 \\
\hline
\end{tabular}

Eficiência média de remoção de DQO 79,2 \pm 9,7 \%

Ao analisar a Figura 5.17 juntamente com a Tabela 5.7, observa-se que o reator 2 apresentou uma queda leve na remoção de DQO para cargas orgânicas de até próximo de 7,0 $\mathrm{kg} / \mathrm{m}^{3} \mathrm{~d}$. Próximo ao final da Fase II observou-se uma queda de quase 15 pontos percentuais da eficiência de remoção de DQO, de aproximadamente $80 \%$ para $65 \%$ de eficiência de remoção, indicando uma nova falha do processamento da vinhaça pré-tratada.

No item 5.4 serão apresentados os resultados de produção de metano para ambos os reatores, e os dados obtidos durante esta análise reforçam o indicativo de uma possível falha no reator 2.

Os valores de DQO afluente e efluente ao reator 2 durante a Fase II são demonstrados na Figura 5.18.

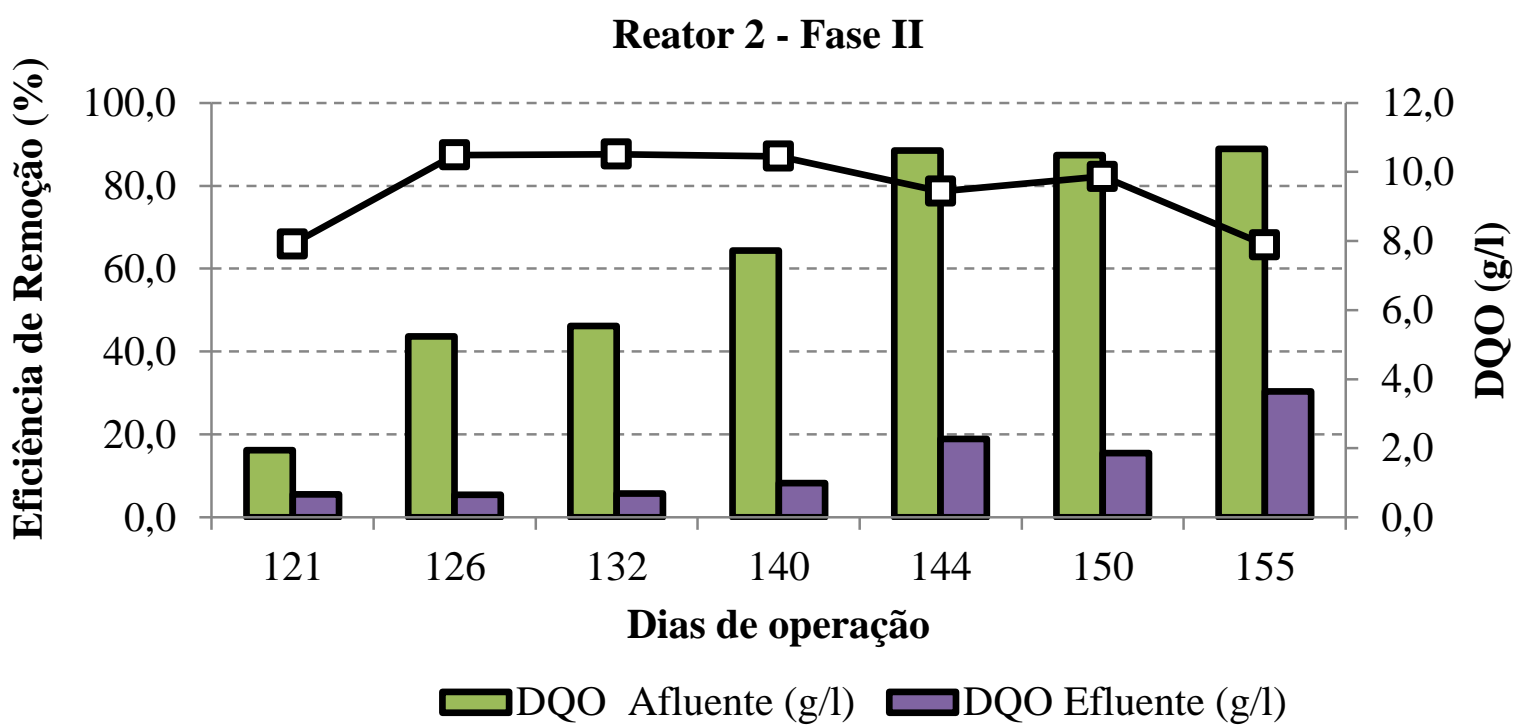

Figura 5.18 - Variação da DQO afluente e efluente ao reator 2 durante a Fase II, e sua respectiva eficiência de remoção de DQO.

A Figura 5.18 apresenta os valores de DQO afluente e efluente ao reator 2, e observa-se uma certa estabilidade do sistema durante a Fase II, entretanto, como já 
mencionado, ao final desta fase ocorre uma queda considerável de eficiência de remoção de DQO em um curto espaço de tempo, indicando novamente uma falha.

O sulfato presente no afluente foi de $614,6 \pm 8,5 \mathrm{mg} / 1$, e no efluente foi de $204,7 \pm$ $4,2 \mathrm{mg} / \mathrm{l}$, resultando em uma eficiência de remoção de $74,8 \pm 0,9 \%$ do sulfato presente na vinhaça.

A eficiência de remoção de DQO foi de 79,2 \pm 9,7 \%, apresentando uma concentração de DQO no efluente de 1,5 $\pm 1,1 \mathrm{~g} / \mathrm{l}$. O sulfato presente no afluente foi de 814,6 $\pm 8,5 \mathrm{mg} / \mathrm{l}$, e no efluente foi de $204,7 \pm 4,2 \mathrm{mg} / \mathrm{l}$, resultando em uma eficiência de remoção de $74,9 \pm 0,9 \%$ do sulfato presente na vinhaça.

O Figura 5.19 ilustra os valores de pH obtidos durante a operação do reator 2 na Fase II.

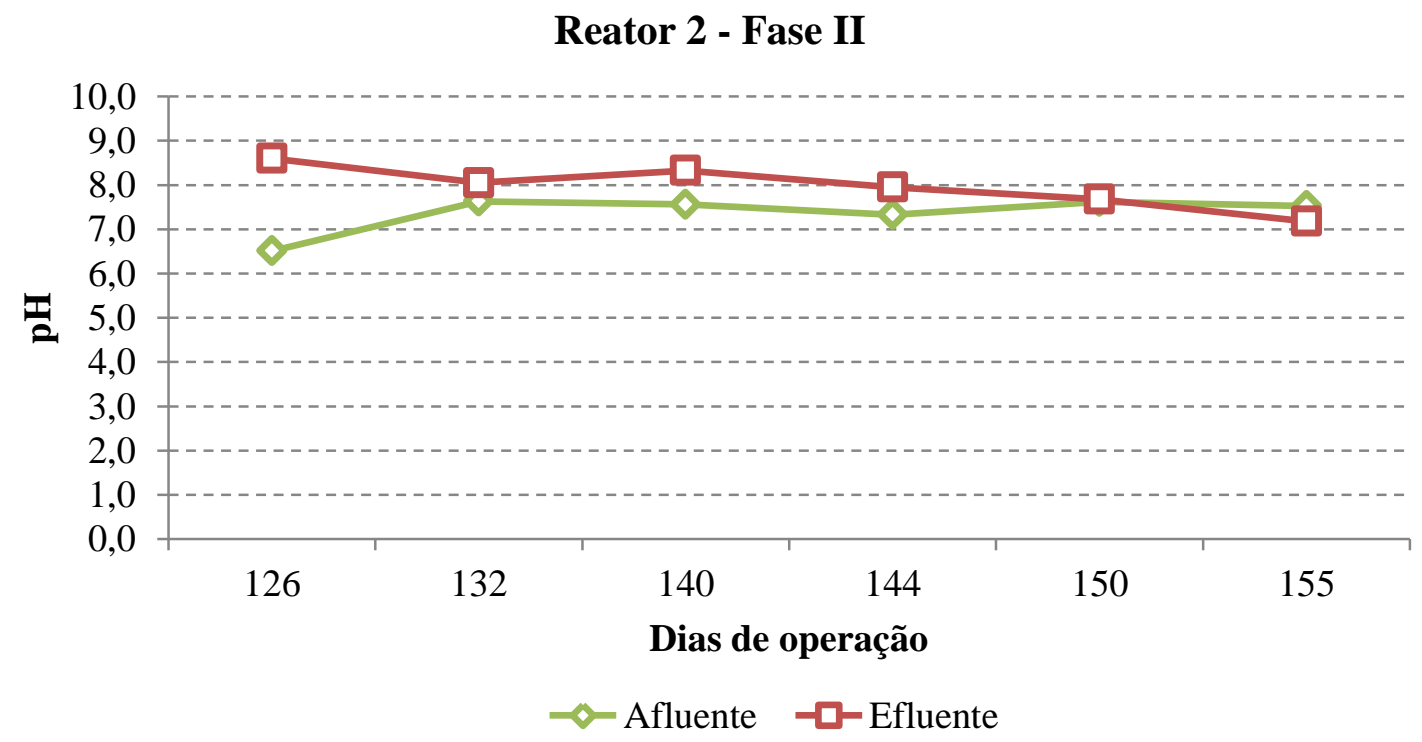

Figura 5.19 - Valores de $\mathrm{pH}$ afluente e efluente ao reator 2 na Fase II

$\mathrm{O}$ pH no sistema nesta fase, como observado na Figura 5.19, apresentou pouca variação, com um valor médio de 7,4 $\pm 0,4$ no afluente e 7,3 $\pm 0,5$ no efluente. Não houve suplementação do afluente com bicarbonato de sódio em todo o período. Estes valores estão na faixa ótima de desenvolvimento dos microrganismos heterotróficos anaeróbios (POSTGATE, 1984).

O comportamento da alcalinidade total durante a Fase II do reator 2 pode ser visualizado na Figura 5.20. 


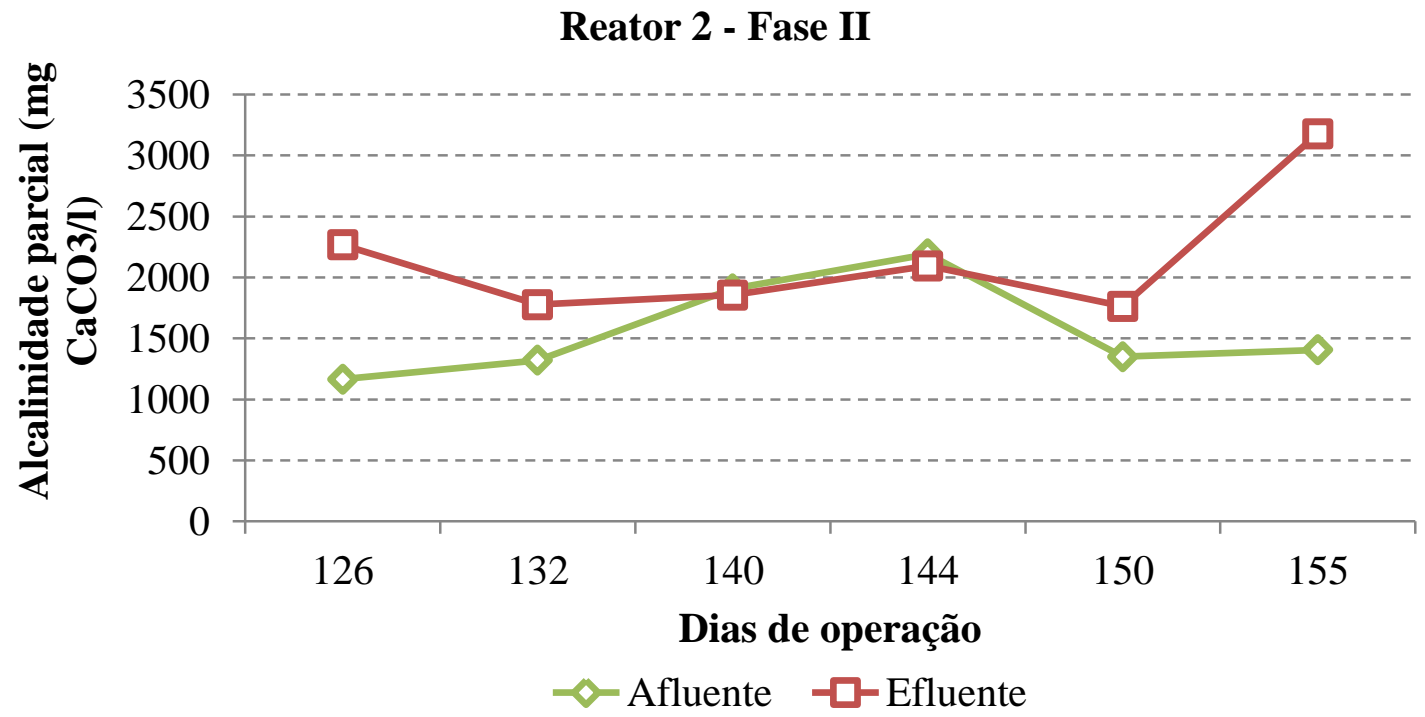

Figura 5.20 - Variação da alcalinidade total do afluente e do efluente do reator 2 durante a Fase II

A alcalinidade do afluente manteve-se estável durante todo o período da Fase II, com média de 1792,8 $\pm 563,7 \mathrm{mg} \mathrm{CaCO}_{3} / \mathrm{l}$. A alcalinidade total do efluente apresentou estabilidade durante quase toda a Fase II, entretanto ao final houve um salto de $1762,2 \mathrm{mg} \mathrm{CaCO}_{3} / 1$ para $3177,2 \mathrm{mg} \mathrm{CaCO} / 1$. Este reator apresentou alcalinidade total média de 2260,3 \pm 914,7 $\mathrm{mg}$ $\mathrm{CaCO}_{3} / 1$.

Comparando os resultados de $\mathrm{pH}$ e alcalinidade, ao final do experimento, percebe-se uma queda de $\mathrm{pH}$ e um aumento de alcalinidade total do efluente, indicando um acúmulo de ácidos graxos voláteis, ocasionando acidificação do reator. Em concordância com a queda de eficiência, estes dados ilustram o início de uma falha prestes a ocorrer no processamento anaeróbio.

\subsection{Produção de Metano}

As Figuras 5.21 e 5.22 apresentam os valores de produção de metano obtidos durantes as Fases I e II, para os reatores 1 e 2. 


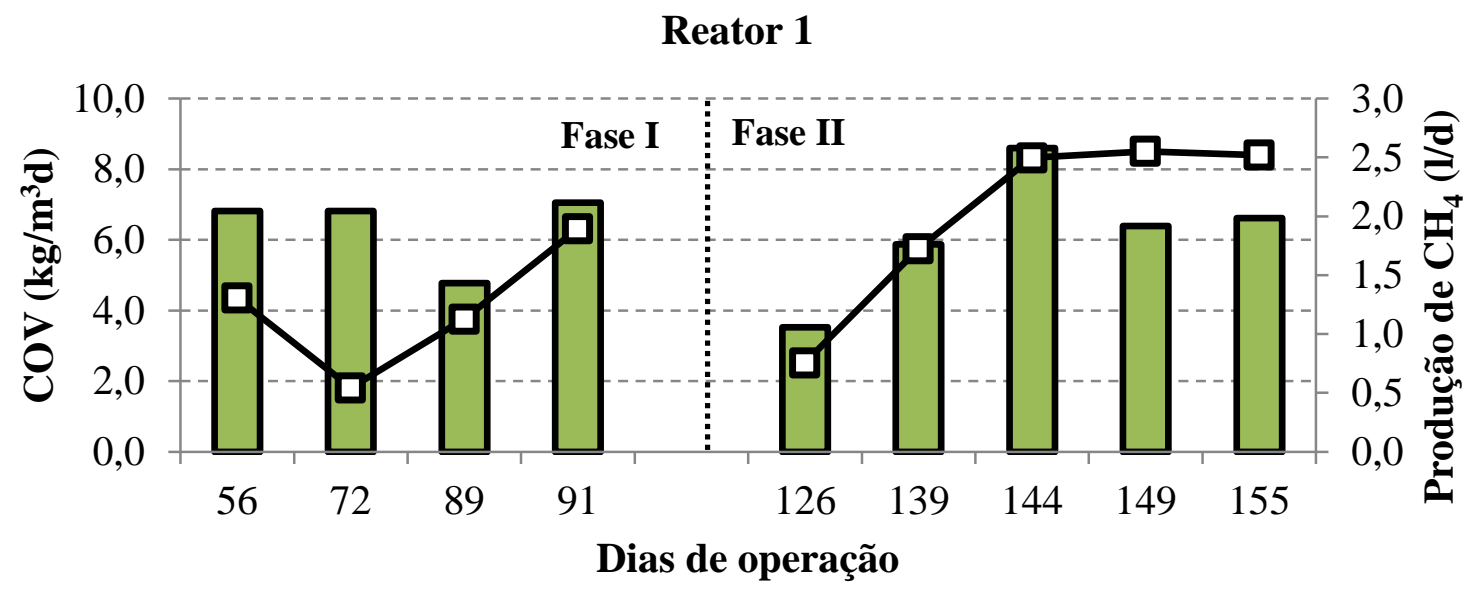

$\square \operatorname{COV}\left(\mathrm{kg} / \mathrm{m}^{3} \mathrm{dia}\right) \quad-\square-\mathrm{Q}(\mathrm{l} / \mathrm{d})$

Figura 5.21 - Produção de metano, em 1/h, em relação à COV aplicada ao reator 1 durante das Fases I e II.

Reator 2

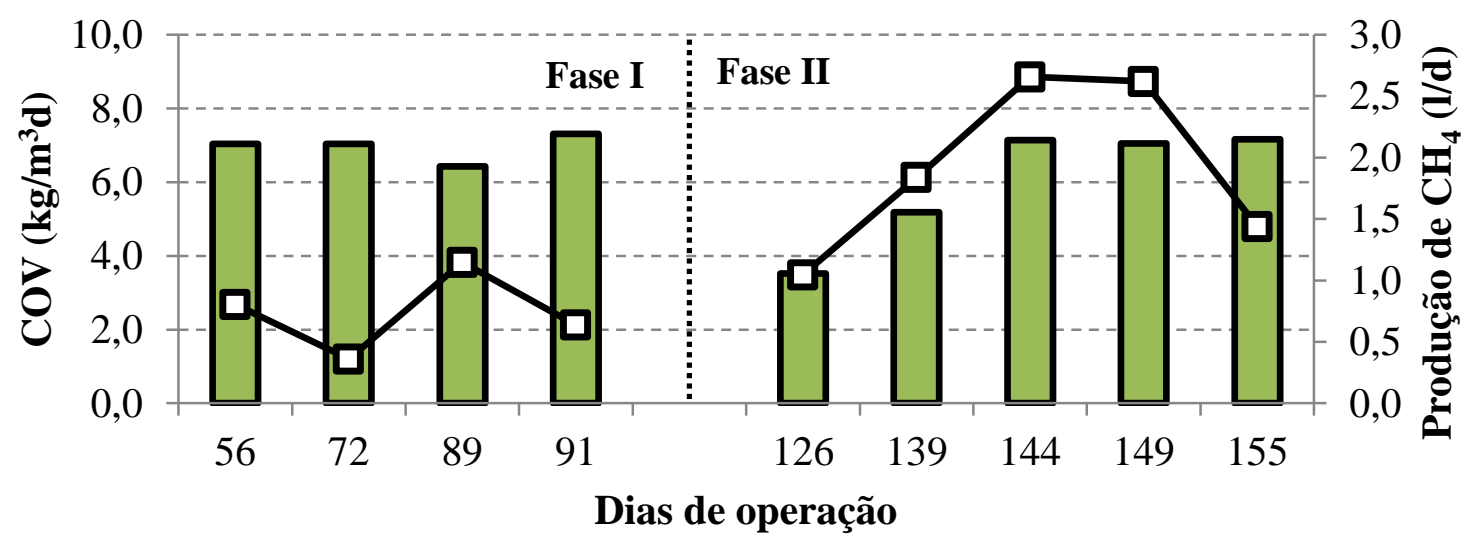

$\square \operatorname{COV}\left(\mathrm{kg} / \mathrm{m}^{3} \mathrm{dia}\right) \quad-\square-\mathrm{Q}(1 / \mathrm{d})$

Figura 5.22 - Produção de metano, em 1/h, em relação à COV aplicada ao reator 2 durante das Fases I e II.

Ao analisar o gráfico correspondente à Fase I nas Figuras 5.21 e 5.22, observa-se um comportamento similar entres os reatores 1 e 2, entretanto, ao final desta fase, a produção de metano no reator 2 apresenta queda, indicando falha no sistema.

A produção média de metano para o reator 1 na Fase I foi de $1,22 \pm 0,561 \mathrm{CH}_{4} / \mathrm{d}$, enquanto a média do reator 2 foi $0,74 \pm 0,33 \mathrm{l} \mathrm{CH}_{4} / \mathrm{d}$. Como pôde-se perceber, a produção de metano referente ao processamento anaeróbio de vinhaça bruta foi superior ao de vinhaça pré-tratada. Logo, além de ocasionar falha no processamento anaeróbio, o uso do biopolímero experimental interfere negativamente na produção de metano. 
A produção média de metano para o reator 1 na Fase II foi de 2,01 $\pm 0,781 \mathrm{CH}_{4} / \mathrm{d}$, enquanto a média do reator 2 foi $1,92 \pm 0,711 \mathrm{CH}_{4} / \mathrm{d}$.

A Figura 5.23 ilustra relação da produção de metano com a DQO de entrada (DQOa) e a DQO removida (DQOr) pelos reatores 1 e 2, em ambas as fases.

\section{Reator 1 - Relação CH4/DQO (1/g)}

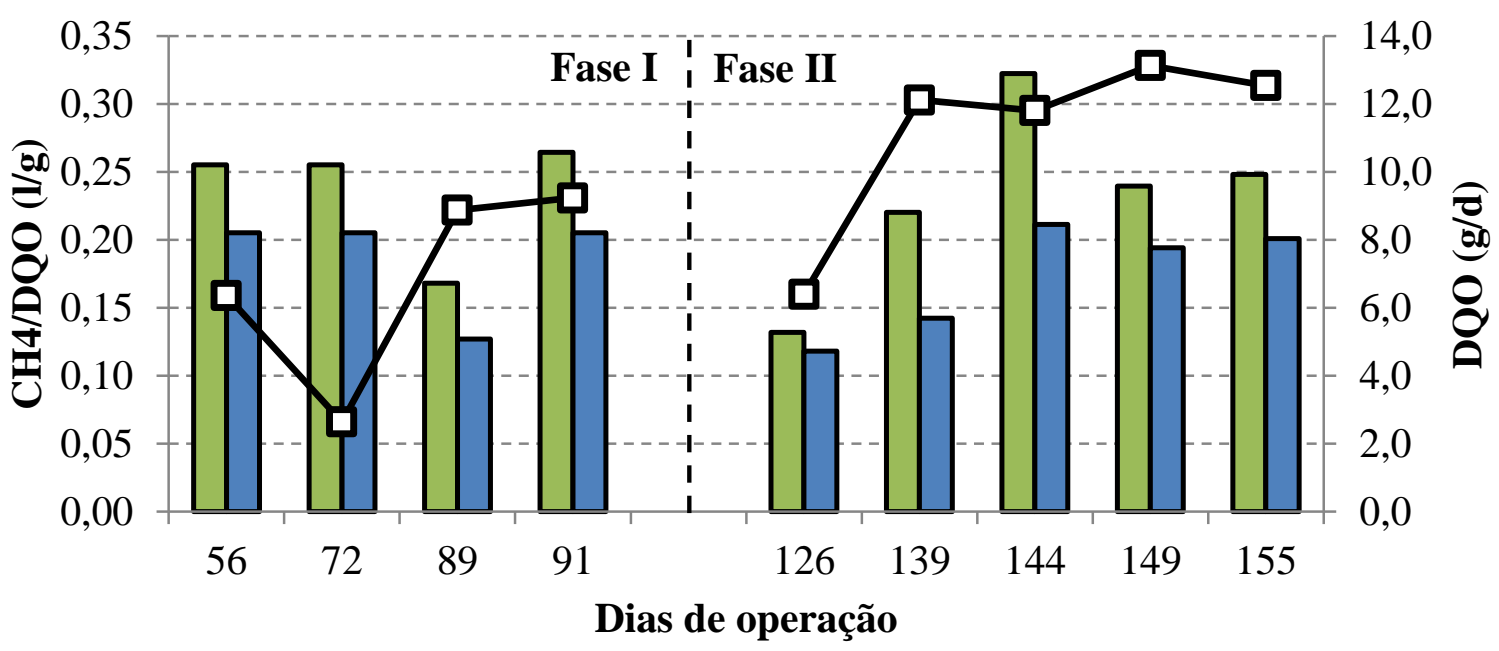

a)

Reator 2 - Relação CH4/DQO (1/g)

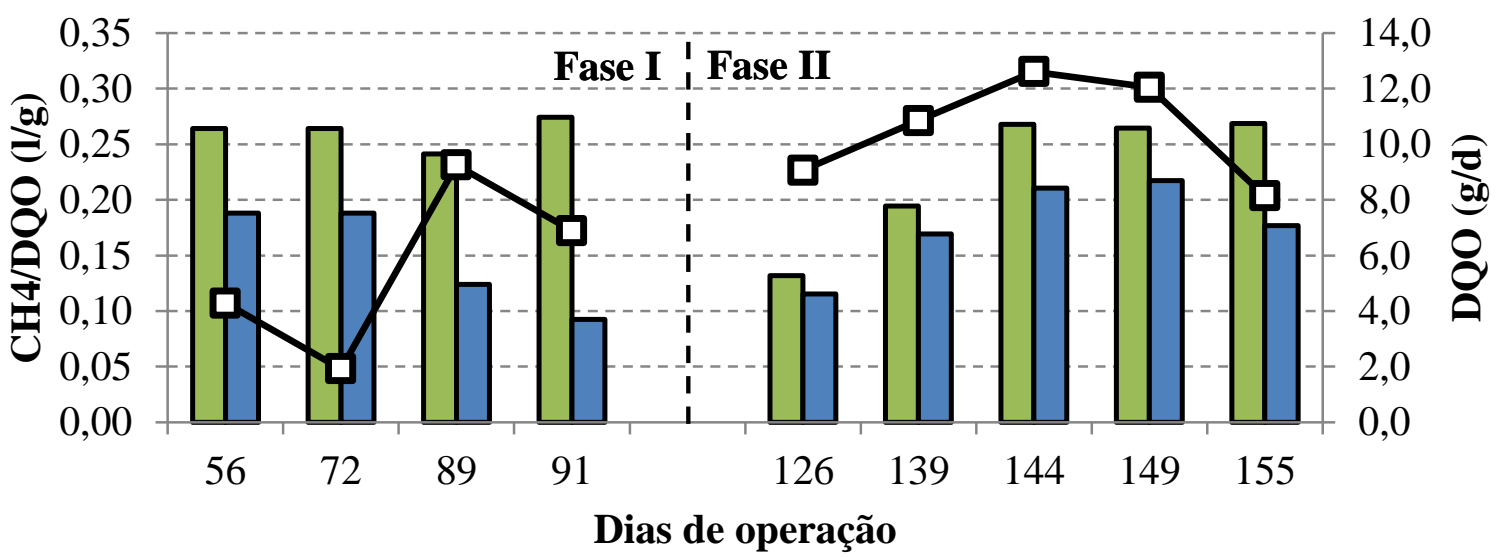

$\square D Q O a(\mathrm{~g} / \mathrm{d}) \quad \square D Q O r(\mathrm{~g} / \mathrm{d}) \quad-\mathrm{C}$ CH4/DQOr (l/g)

b)

Figura 5.23 - Produção de $\mathrm{CH}_{4}$ relacionada à DQO removida (DQOr) para os reatores 1 (a) e 2 (b), durante as Fases I e II.

A relação $\mathrm{CH}_{4} / \mathrm{DQO}$ indica a quantidade de metano com origem na DQO removida gerada pelo processo anaeróbio. Desta forma, observa-se na Figura 5.23 a estreita relação entre a produção de $\mathrm{CH}_{4}$ e a remoção de DQO, e, de fato, em ambas as fases de operação dos reatores, exceto pela amostragem feita no $72^{\circ}$ dia. Esta queda de produção, para ambos os reatores, provavelmente está ligada a algum fator externo que influenciou o sistema. 
Na Figura 5.21b é ilustrada esta relação $\mathrm{CH}_{4} / \mathrm{DQOr}$ para o reator 2. Observa-se que, para as duas fases, ao final da operação há uma queda na produção de metano juntamente com uma queda nos valores de DQO removida. Na Fase I foi observada uma falha neste reator, como já mencionado anteriormente. Entretanto, apesar de na Fase II não ser concreta a afirmação de uma falha iminente, a relação entre DQOr e $\mathrm{CH}_{4}$ indica esta possível falha. Juntamente a estas afirmações, é possível analisar pela Figura 5.23 a relação DQO afluente e removida. Para o reator 1 observa-se uma certa constância na relação DQOa/DQOr, sendo esta de 1,27 \pm 0,04 para a Fase I, e 1,33 \pm 0,19 para a Fase II. Porém, ao analisar os dados

para o reator 2, observa-se que esta relação fica maior ao final de cada Fase, sendo 1,93 \pm 0,73 para a Fase I e 1,25 \pm 0,15 para a Fase II. Apenas deste último valor ser próximo ao encontrado no reator 1 , a relação DQOa/DQOr para a última data de amostragem do reator 2 na Fase II é 1,52, maior do que a média do reator 1 em ambas as fases.

\subsection{Comparação Estatística do Desempenho dos Reatores}

No item 5.3 foram discutidos individualmente os resultados de remoção de DQO dos reatores para cada fase desta pesquisa. Contudo, para melhor entendimento de todo o processo, no presente item será feita uma discussão comparativa entre os reatores e suas fases de operação.

Nas Figuras 5.24 e 5.25 estão apresentados gráficos Box-plot de distribuição de eficiência de remoção de DQO para os dois reatores, nas duas fases desta pesquisa. A representação Box-plot é uma ferramenta estatística que possibilita a visualização da distribuição dos pontos amostrados. Apresentado no box estão a mediana (50\%), o primeiro quartil (25\%), o terceiro quartil (75\%) e a média. São discriminados também os valores máximos e mínimos desta distribuição. Para este tipo de representação, quanto maior a altura do box interior, maior será o desvio padrão, consequentemente, maior será a heterogeneidade das amostras. 


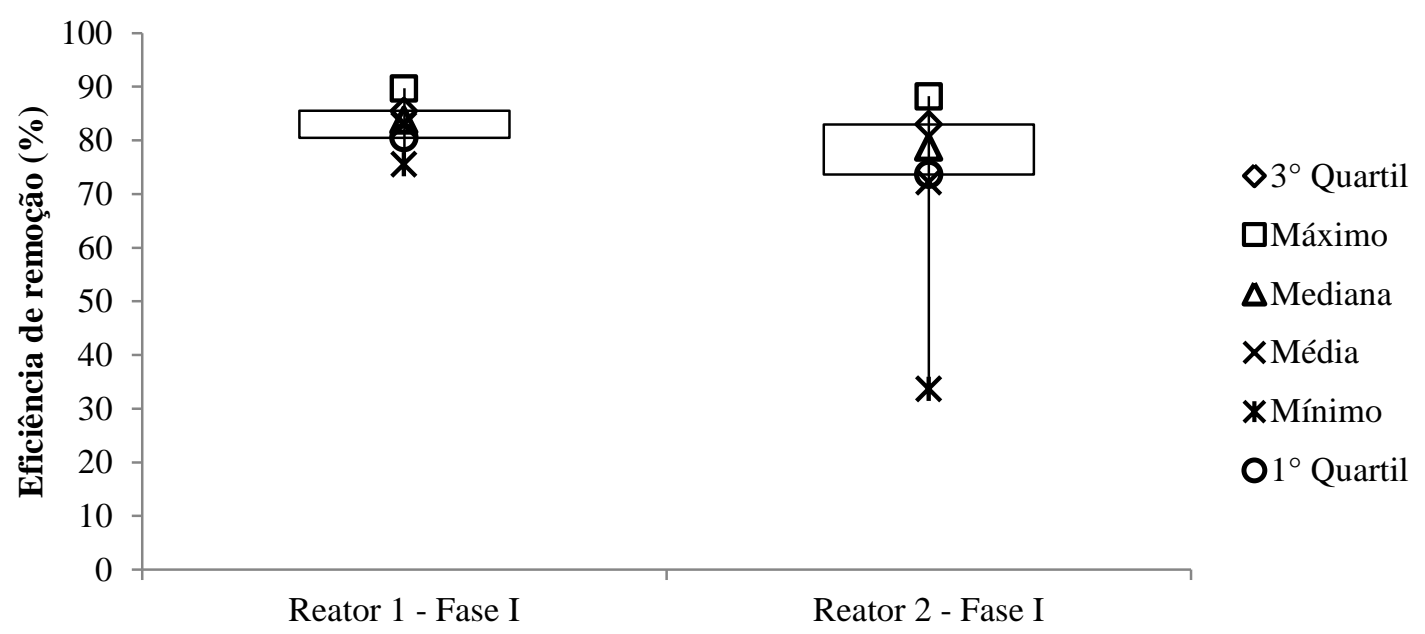

Figura 5.24 - Gráfico Box-plot de distribuição de resultados de eficiência de remoção de DQO dos reatores 1 e 2, para a Fase I.

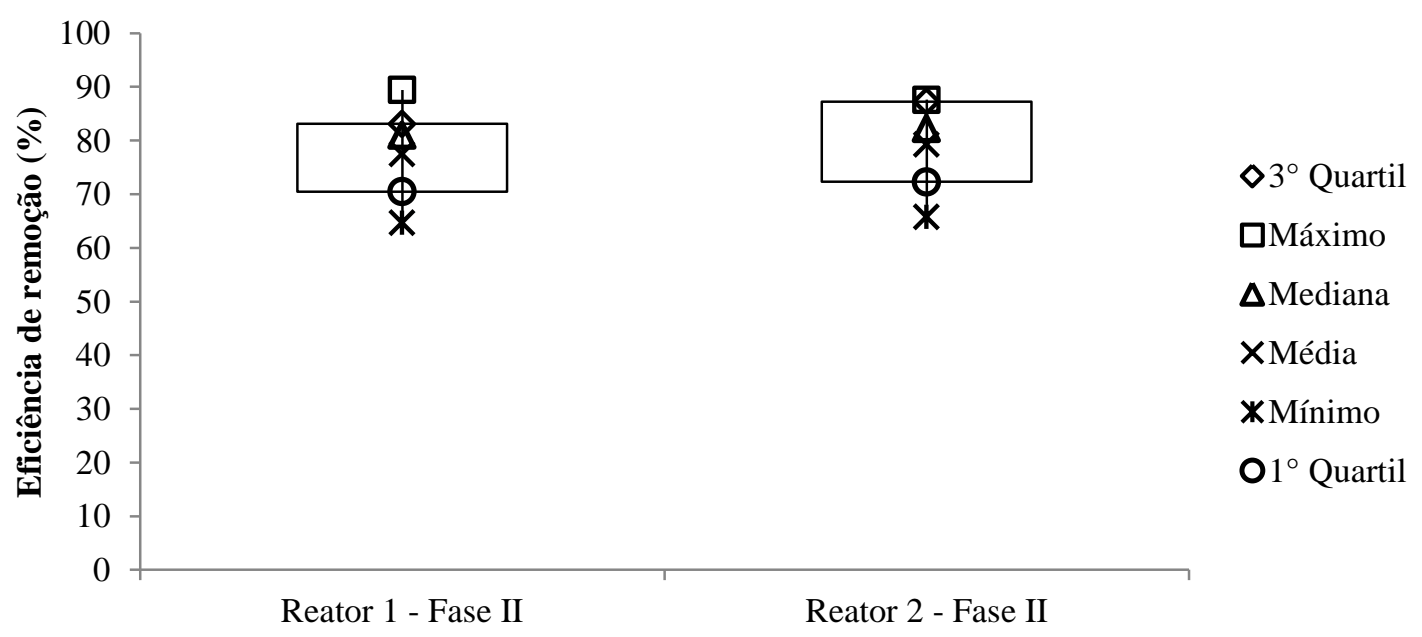

Figura 5.25 - Gráfico de Box-plot de distribuição dos resultados da eficiência de remoção de DQO dos reatores 1 e 2, para a Fase II

Observa-se que, para as duas fases desta pesquisa o reator 1 apresentou pouca variação na eficiência de remoção, representado pela altura do box. Entretanto, o reator 2 apresentou maior variação, sendo mais evidente na Fase I, onde, de fato, ocorreu a falha no sistema.

Foram feitos testes comparativos entre os reatores, em termos de eficiência de remoção, com o teste t de Student. Foi utilizado o software SigmaStat 3.5 para estas análises.

Através desta análise estatística, concluiu-se que os reatores são estatisticamente iguais, tanto para a Fase I, quanto para Fase II, isto é, enquanto estão funcionando normalmente. O problema está em relação ao reator 2, que, repentinamente entra em colapso. Isto retira o comportamento normal do reator, ocasionando uma falha inicial no teste. Mas, 
automaticamente, o software faz adaptações dos dados e realiza esta análise, retirando os dados que prejudicam a normalidade.

Os resultados das análises feitas pelo software estão contidos no Apêndice.

\subsection{Análises do Lodo Granular presente no Inóculo, reator 1 e reator 2}

Neste tópico serão discutidas aos resultados obtidos em análises do lodo granular do inóculo, reator 1 e reator 2. Foram feitas amostragem dos lodos granulares ao final do experimento, e o lodo referente ao inóculo foi preservado durante todo o monitoramento dos reatores à $4^{\circ} \mathrm{C}$. Foram feitos ensaios de resistência dos grânulos, análises de microscopia eletrônica de varredura (MEV) e da comunidade microbiana, empregando técnicas de biologia molecular.

\subsubsection{Microscopia Eletrônica de Varredura (MEV)}

Foram analisadas as imagens do lodo granular do inóculo e dos reatores monitorados. Juntamente com as imagens obtidas, foram feitas análises de espectrometria de energia dispersiva de Raios-X (EDS), fornecendo os compostos presentes nas amostras.

As Figuras 5.26, 5.27 e 5.28 demonstram imagens em micrografia eletrônica de varredura dos grânulos analisados. Também foram feitas análises de EDS correspondente a estas figuras.

Durante a análise das imagens obtidas pôde-se observar uma mudança evidente na estrutura superficial dos grânulos. A diferença mais evidente foi a elevada rugosidade na superfície dos grânulos dos reatores 1 e 2, em comparação com o inóculo. Supõe-se que esta rugosidade é devida ao depósito de substâncias inorgânicas presente na vinhaça e no biopolímero experimental.

Foram observadas diferenças na superfície entre os grânulos dos dois reatores, sendo que os grânulos do reator 2 apresentaram maior rugosidade. A substância inorgânica em maior quantidade, neste caso, provavelmente é o cálcio, pois aparentemente a rugosidade é 
devida a depósitos deste elemento na superfície dos grânulos, conforme evidenciado por análises de EDS.

Análises de Espectrometria de Energia Dispersiva de Raios-X (EDS) feitas durante a captura das imagens reforçam esta teoria do depósito de cálcio na superfície dos grânulos. A Tabela 5.8 e a Figura 5.29 ilustram os resultados destas análises.

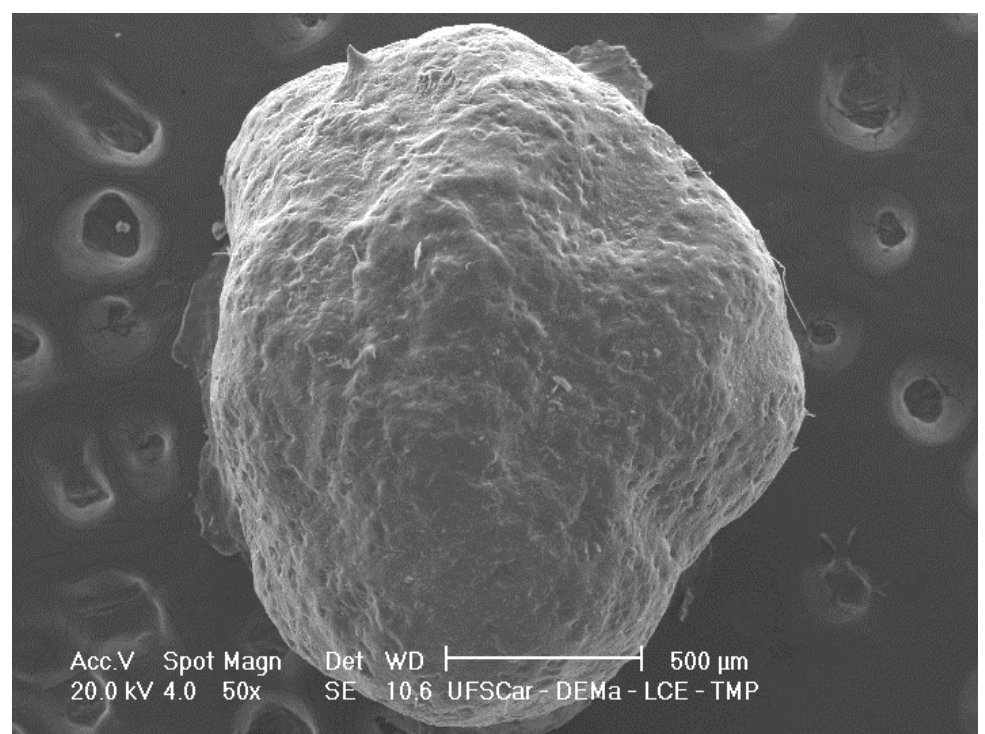

Figura 5.26 - Micrografia eletrônica de varredura de grânulo de reator UASB; Inóculo.

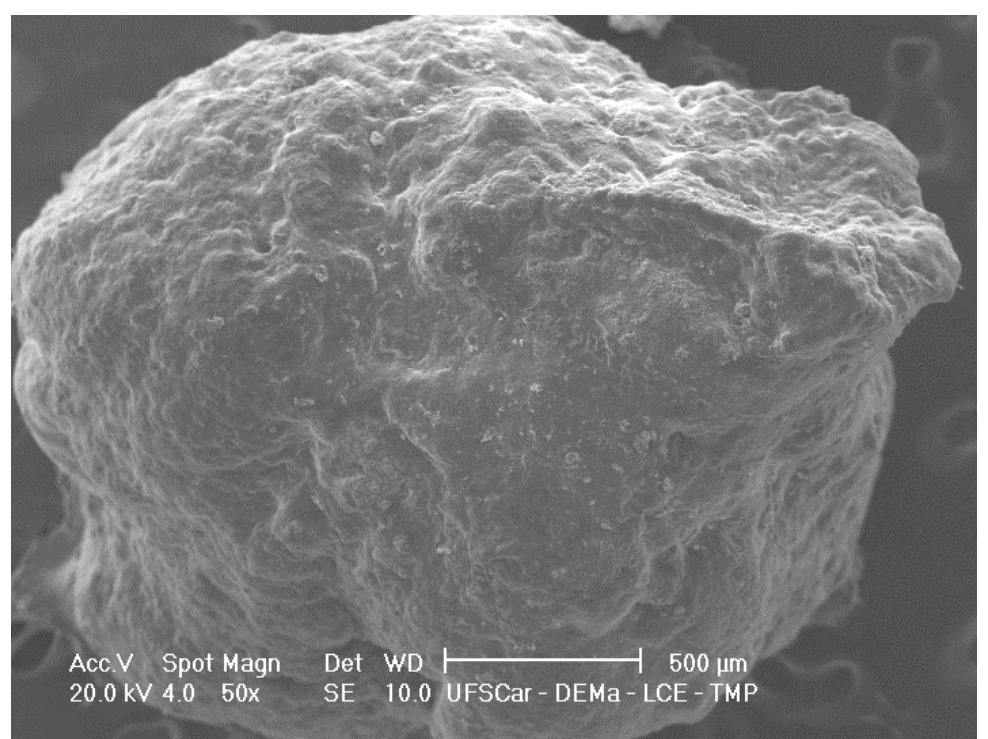

Figura 5.27 - Micrografia Eletrônica de Varredura de grânulo de reator RAHBI; Reator 1. 


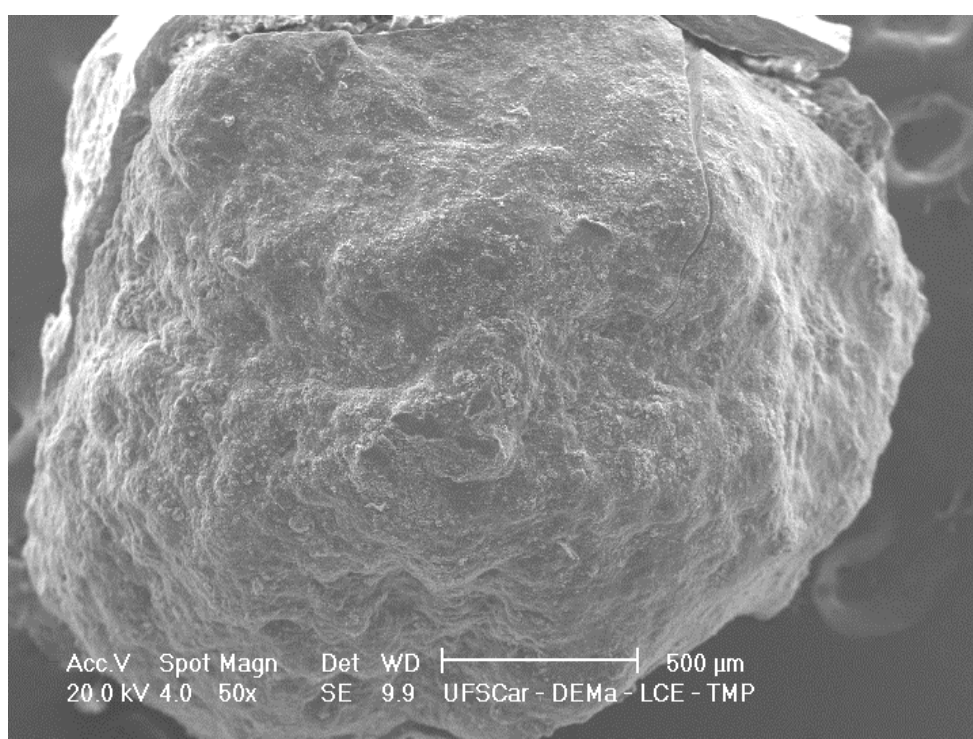

Figura 5.28 - Micrografia Eletrônica de Varredura de grânulo de reator RAHBI; Reator 2.

Tabela 5.8 - Análise de EDS para os grânulos do inóculo e reatores 1 e 2

\begin{tabular}{cccc}
\multirow{2}{*}{ Elemento } & \multicolumn{3}{c}{ Porcentagem na Amostra (\%) } \\
\cline { 2 - 4 } & Inóculo & Reator 1 & Reator 2 \\
\hline $\mathrm{Si}$ & 35,20 & 1,81 & 1,67 \\
$\mathrm{~S}$ & 12,69 & 41,70 & 16,35 \\
$\mathrm{~K}$ & 5,51 & 6,45 & 4,84 \\
$\mathrm{Ca}$ & $\mathbf{2 2 , 9 1}$ & $\mathbf{3 9 , 0 8}$ & $\mathbf{4 9 , 9 0}$ \\
$\mathrm{Fe}$ & 23,67 & 10,96 & 27,25 \\
$\mathrm{Si}=$ Silica; $\mathrm{S}=$ Enxofre; $\mathrm{K}=$ Potássio; $\mathrm{Ca}=$ Cálcio e Fe = Ferro.
\end{tabular}
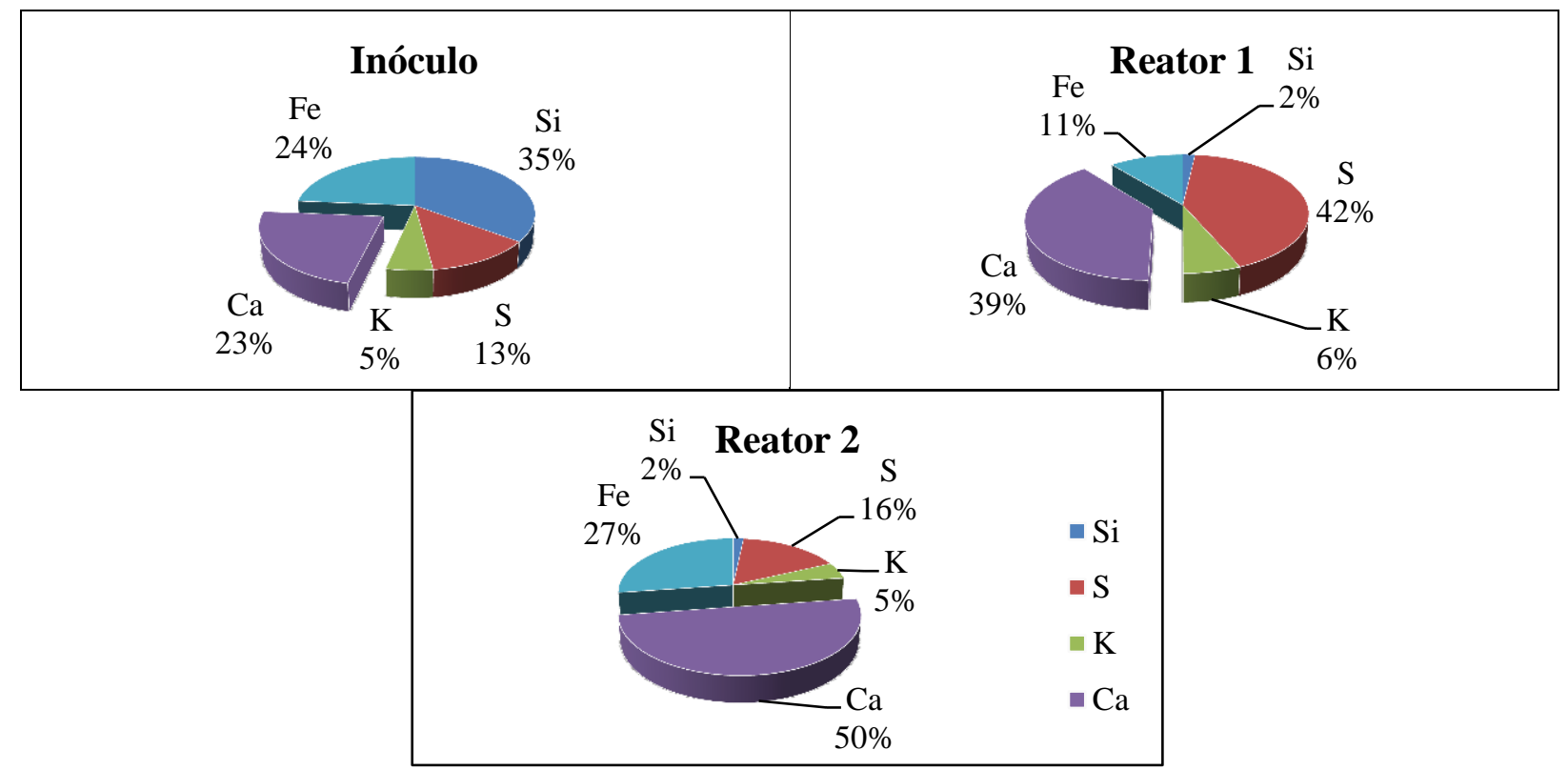

Figura 5.29 - Distribuição percentual dos elementos analisados em EDS nas amostras de lodo granular do inóculo e reatores 1 e 2. 
Destacam-se na Tabela 5.8 as diferenças de cálcio presentes nos três tipos de grânulos.

Os elementos sílica e cálcio são parte inerente da constituição de lodos granulares, pois estes possuem função de núcleo do grânulo e são suportes para a fixação das arqueias e bactérias, conferindo o formato esférico do grânulo.

A caracterização da vinhaça apresentou uma concentração média de aproximadamente $1400 \mathrm{mg} \mathrm{Ca} / \mathrm{l}, \operatorname{logo}$ era de se esperar um aumento da concentração de cálcio nas amostras retiradas dos reatores. Além de a vinhaça possuir uma alta concentração de cálcio, o elemento básico do biopolímero experimental é o óxido de cálcio $(\mathrm{CaO}), \log$ a vinhaça pré-tratada possui uma concentração ainda maior de cálcio. Portanto, era previsível um aumento da concentração de cálcio nos grânulos do reator 2 .

É possível verificar nas Figuras 5.30 e 5.31 a deposição de um composto a base de cálcio nos grânulos do reator 2. As setas indicam algumas das deposições de cálcio.

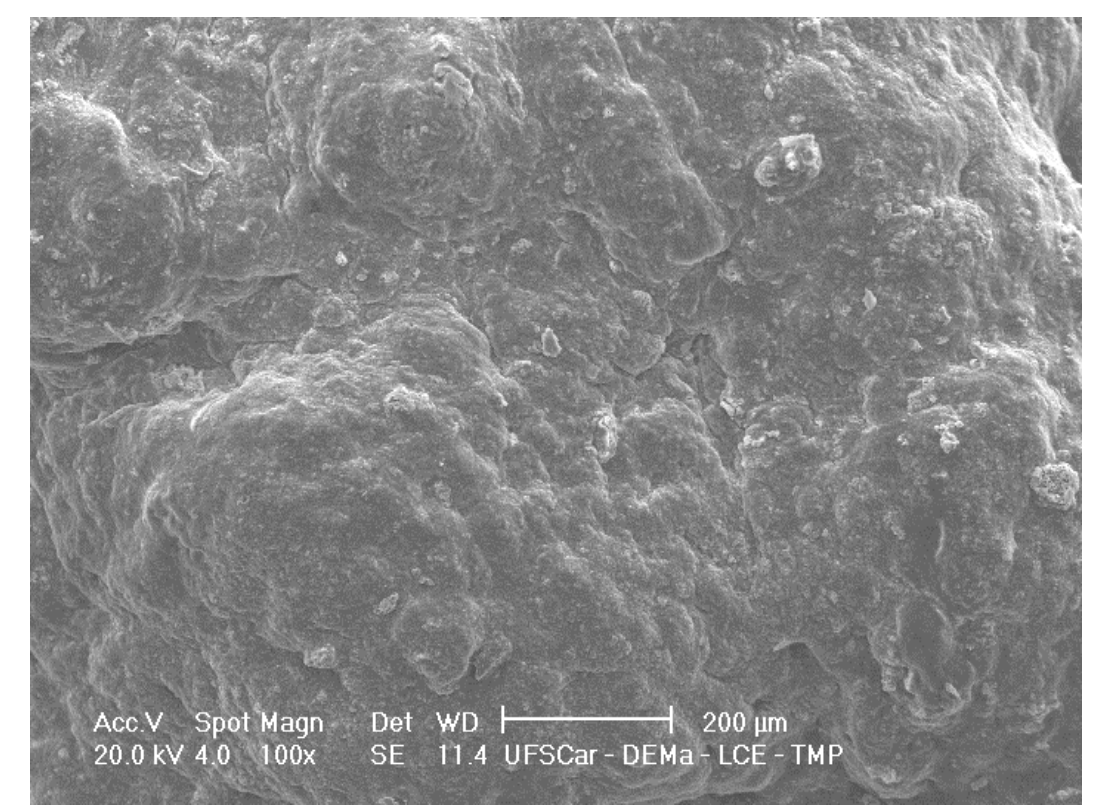

Figura 5.30 - Micrografia Eletrônica de Varredura da superfície de um grânulo retirado do reator 1 . 


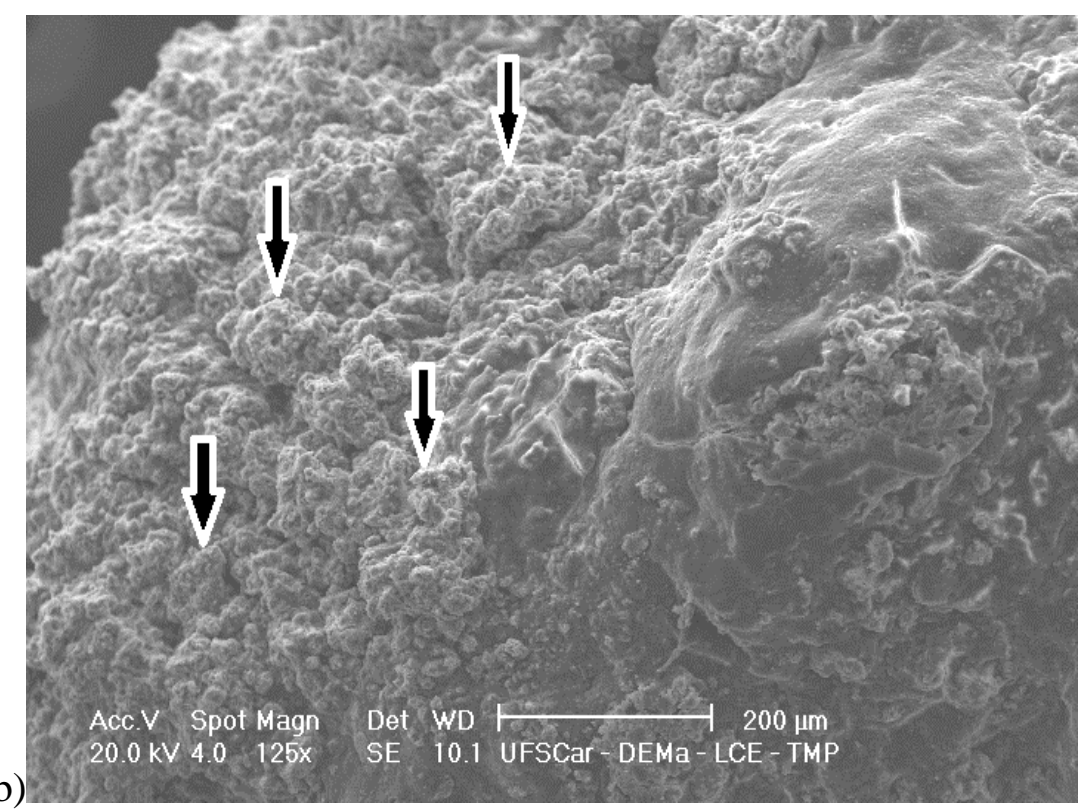

Figura 5.31 - Micrografia Eletrônica de Varredura da superfície de um grânulo retirado do reator 2 .

Observa-se que o grânulo do reator 1 possui superfície menos rugosa quando comparado ao grânulo do reator 2. Esta rugosidade elevada provavelmente está relacionada com a deposição de cálcio proveniente do biopolímero. Esta constatação reforça a hipótese de que o motivo da falha observada no reator 2 foi o excesso de cálcio, que agiu como composto inibidor do processamento anaeróbio da vinhaça.

VAN LANHERAK et al. (1998) consideraram que a precipitação de carbonato de cálcio pode influenciar na atividade da biomassa. Esta precipitação está relacionada na concentração do íon $\mathrm{Ca}^{+2}$ e na eficiência de remoção de DQO. O impacto do precipitado na biomassa é complexo, e a influência deste nos grânulos está relacionado na queda de atividade causado pela limitação na transferência de massa. Entretanto, a biomassa ativa pode ser formada em camadas finas de biofilmes na superfície do precipitado. Portanto, a atividade líquida (total) da biomassa seria a média destes dois efeitos. (VAN LANHERAK, 1998).

Desta forma, pode-se basear a falha ocorrida no reator 2, nas duas fases de operação, na deposição de cálcio na superfície da biomassa, dificultando a transferência de massa entre os grânulos e o substrato (vinhaça). 


\subsubsection{Análise Qualitativa da Comunidade Microbiana presente no Inóculo, reator 1 e reator 2}

Foram coletadas amostras do inóculo e do lodo na parte inferior e superior do reator no final da operação do reator. O lodo da parte inferior apresentou-se com características floculenta, enquanto o lodo na parte superior possuía forma granular, para ambos os reatores. A partir dessas alíquotas foi realizada a extração do DNA genômico (GRIFFITHS et al., 2000) para o exame de PCR (Reação em Cadeia Polimerase) e DGGE (Eletroforese em Gel com Gradiente de Desnaturante), com o objetivo de caracterizar-se a microbiota dos Domínios Bacteria (MUYZER et al, 1996) e Archaea (KUDO et al, 1997), presentes no reator.

Para a comparação entre os diferentes perfis de bandas foram construídos dendrogramas (programa Bionumerics, versão 2.5), para ambos os domínios e analisados pelo índice de similaridade de Jaccard (GOODALL, 1966), que considera a presença e ausência de bandas.

As Figuras 5.32 e 5.33 contêm os dendrogramas obtidos durante esta análise.
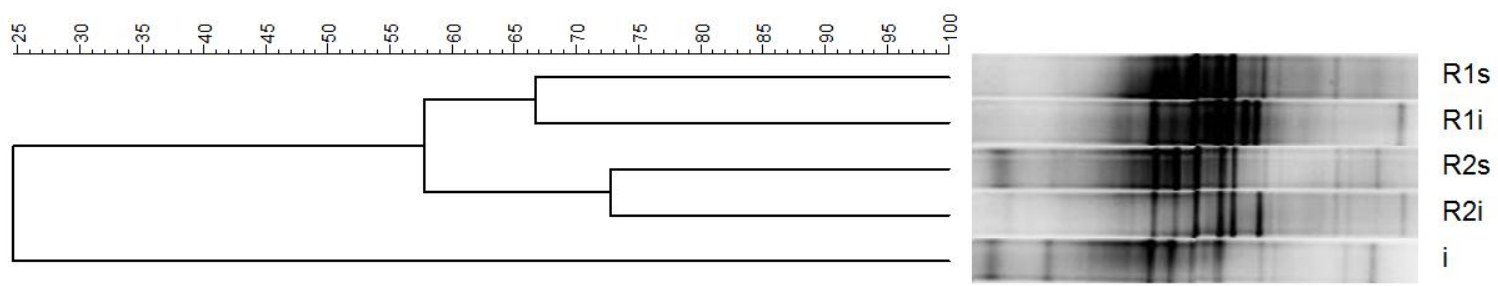

Figura 5.32 - Dendrograma relativo aos perfis de bandas do Domínio Archaea e os respectivos índices de similaridade em porcentagem (Jaccard).
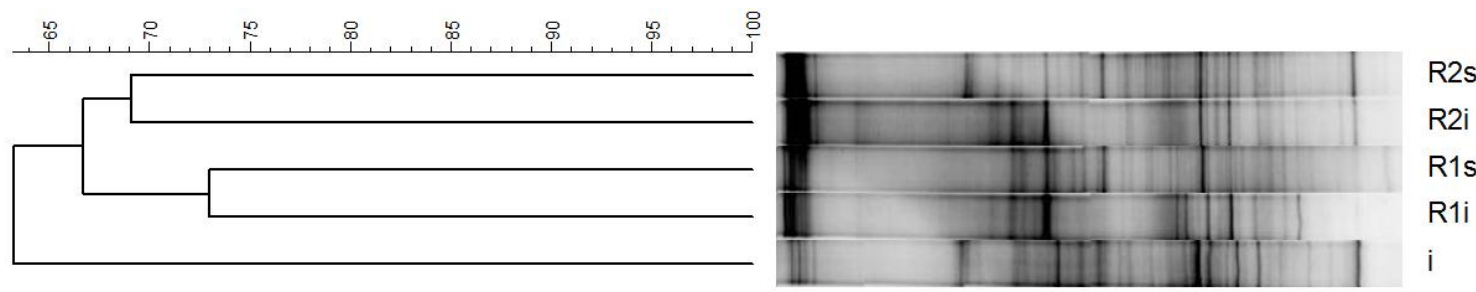

Figura 5.33 - Dendrograma relativo aos perfis de bandas do Domínio Bacteria e os respectivos índices de similaridade em porcentagem (Jaccard).

$\mathrm{R} 1 \mathrm{~s}=$ Região superior do Reator $1 ; \mathrm{R} 1 \mathrm{i}=$ Região inferior do Reator 1 ; R2s $=$ Região superior do Reator 2; R2i = Região inferior do Reator 2; e i = inóculo. 
Para ambos os domínios houve alteração nos perfis de bandas do gel de DGGE entre a microbiota do inóculo e dos inóculos adaptados, ou seja, a comunidade microbiana diferiu em 37\% para domínio Archaea (Figura 5.27) e em 75\% para o domínio Bacteria (Figura 5.28), quando submetido à vinhaça com e sem pré-tratamento, R2 e R1, respectivamente.

Com relação ao domínio Archaea, podem-se observar similaridades de:

- $25 \%$ entre os perfis i e R1/R2;

- $58 \%$ entre os perfis R1 e R2;

- $66,5 \%$ entre os perfis R1i e R1s; e

- $72,5 \%$ entre os perfis R2i e R2s.

Estes resultados indicam que houve uma diferença entre os reatores, tal alteração possivelmente é devida à diferença entre as características dos substratos, ou seja, vinhaça pura e vinhaça coagulada com o biopolímero experimental. Em relação às amostragens em diferentes regiões dos reatores, nota-se um alto índice de semelhança entre elas, indicando que não há muita diferença entre a biota presente na parte superior do reator e parte inferior.

Com relação ao domínio Bacteria o agrupamento entre os perfis de bandas para as biomassas analisadas, mostrou-se diferente com relação ao domínio Bacteria. Os índices de similaridade para o domínio Archaea foram significativamente menores do que os índices calculados para o domínio Bacteria.

Observam-se similaridades de:

- $63 \%$ entre os perfis i e R1/R2;

- $66,5 \%$ entre os perfis i e R1 e R2;

- $73 \%$ entre os perfis i e R1i e R1s, e;

- $69 \%$ entre os perfis i e R2i e R2s.

Observa-se que a comunidade de arqueias mostrou-se mais estável para todas as condições operacionais estudadas. A maior estabilidade das arqueias metanogênicas quando comparadas com a comunidade bacteriana, pode estar relacionada com o fato de que são as bactérias que têm o primeiro contato com a água residuária. No processo de degradação da matéria orgânica são as bactérias fermentativas e acidogênicas as que têm que realizar toda a transformação e preparar o substrato utilizável para as arqueias metanogênicas. Dependendo do tipo e origem da água residuária, da concentração de matéria orgânica, as bactérias precisam alterar sua estrutura e quantidade para conseguir se adaptar. 


\subsubsection{Resistência Mecânica dos Grânulos}

Foram coletados grânulos dos dois reatores operados nesta pesquisa e do inóculo, e a partir de um teste de força mecânica de cisalhamento chegaram-se aos valores contidos nas Tabelas 5.9 e 5.10 .

Considerando que os grânulos são esferas perfeitas, para fins de melhor visualização dos dados, converteu-se as unidades área $\left(\mathrm{mm}^{2}\right)$ em diâmetro $(\mathrm{mm})$, apresentados pela Tabela 5.9. Entretanto, para fins de comparação entre os dados obtidos e as análises estatísticas, mantiveram-se os dados de área $\left(\mathrm{mm}^{2}\right)$.

Tabela 5.9 - Valores médios do diâmetro dos grânulos antes e após o teste de resistência mecânica.

\begin{tabular}{ccccccc}
\hline Diâmetro & \multicolumn{2}{c}{ Inóculo } & \multicolumn{2}{c}{ Reator 1 } & \multicolumn{2}{c}{ Reator 2 } \\
\cline { 2 - 7 }$(\mathbf{m m})$ & $\mathbf{0}$ & $\mathbf{1}$ & $\mathbf{0}$ & $\mathbf{1}$ & $\mathbf{0}$ & $\mathbf{1}$ \\
\hline Média & 4,92 & 4,31 & 4,43 & 4,27 & 4,67 & 4,31 \\
Desvio & 0,54 & 0,92 & 0,43 & 0,47 & 0,48 & 0,50 \\
Padrão & \multicolumn{3}{r}{$\mathbf{0}$ - Antes do teste de resistência; $\mathbf{1}$ - Depois do teste de resistência. }
\end{tabular}

Tabela 5.10 - Dados estatísticos descritivos obtidos no cálculo das áreas médias dos grânulos, em $\mathrm{mm}^{2}$.

\begin{tabular}{rcccccc}
\hline & \multicolumn{2}{c}{ Inóculo } & \multicolumn{2}{c}{ Reator 1 } & \multicolumn{2}{c}{ Reator 2 } \\
\cline { 2 - 7 } & $\mathbf{0}$ & $\mathbf{1}$ & $\mathbf{0}$ & $\mathbf{1}$ & $\mathbf{0}$ & $\mathbf{1}$ \\
\hline Média & 19,21 & 15,63 & 15,58 & 14,48 & 17,31 & 14,80 \\
Desvio Padrão & 4,22 & 4,26 & 2,99 & 3,19 & 3,55 & 3,38 \\
Erro Padrão & 0,68 & 0,68 & 0,49 & 0,49 & 0,55 & 0,56 \\
Mínimo & 11,37 & 6,43 & 10,35 & 8,68 & 10,52 & 8,06 \\
Máximo & 29,73 & 28,33 & 21,77 & 21,60 & 25,95 & 23,15 \\
\hline \multicolumn{0}{c}{ 0 Antes do teste de resistência; $\mathbf{1}-$ Depois do teste de resistência. }
\end{tabular}

Os resultados contidos na Tabela 5.10 indicam que para todas as condições ensaiadas não houve desintegração dos grânulos. Observa-se, também, pelos dados obtidos que as médias antes e depois do teste de resistência ao cisalhamento apresentam queda em todos os grânulos amostrados. Nota-se que os valores mínimos encontrados sempre foram menores nos grânulos submetidos ao teste de força de cisalhamento, indicando uma redução do tamanho dos grânulos. 
Os grânulos do inóculo possuem área média de 19,21 \pm 4,22 mm², e após a aplicação da força de cisalhamento houve uma redução para 15,63 $\pm 4,26 \mathrm{~mm}^{2}$. Observa-se que os grânulos dos reatores 1 e 2 tiveram comportamentos parecidos em relação ao teste de resistência. Os grânulos do reator 1 apresentaram média de 15,58 \pm 2,99 $\mathrm{mm}^{2}$ e 14,48 \pm 3,19 $\mathrm{mm}^{2}$, antes e após o teste, respectivamente. Os grânulos do reator 2 tiveram média de 17,31 \pm $3,55 \mathrm{~mm}^{2}$ antes do teste, e $14,80 \pm 3,38 \mathrm{~mm}^{2}$ depois do teste.

\subsubsection{Análise estatística dos dados obtidos no teste de resistência mecânica dos grânulos}

Os resultados do teste t de Student realizado nas amostras dos grânulos do inóculo, reator 1 e reator 2 são mostrados a seguir. As Figuras 5.32, 5.34 e 5.36 apresentam gráficos do tipo Box-plot para cada amostragem.

- Inóculo

De acordo com o teste $\mathrm{t}$ de Student realizado para as amostras de grânulos do inóculo, foi encontrado o seguinte resultado:

- a diferença entre os valores médios dos dois grupos é maior do que o esperado, logo, as amostras são estatisticamente diferentes, em um nível de 95\% de confiança.

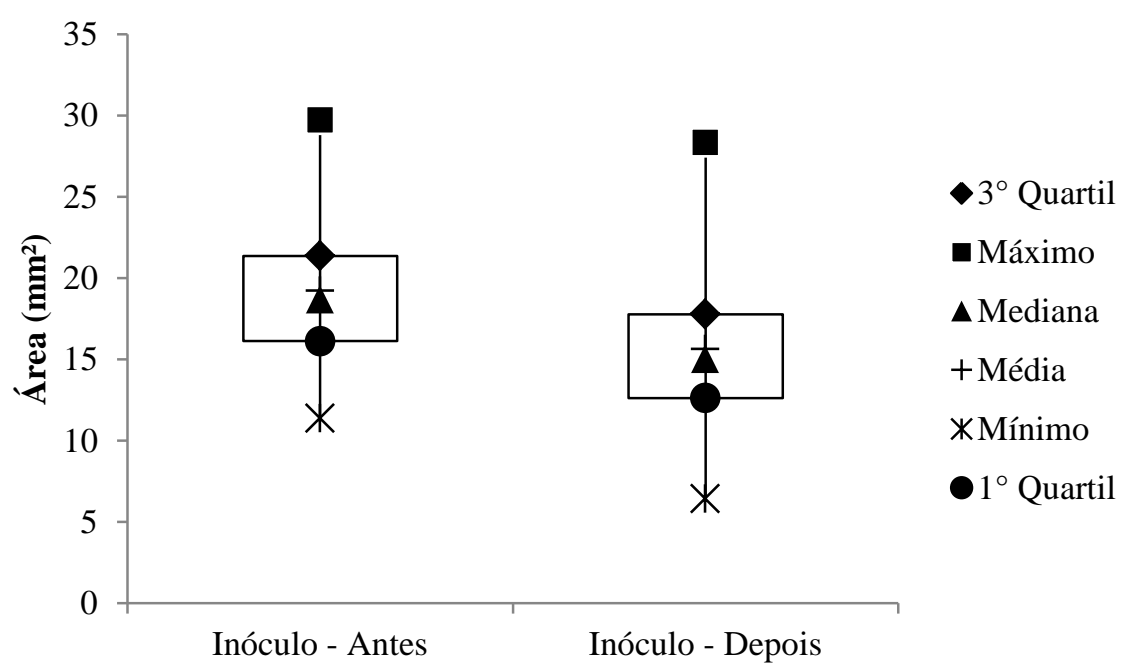

Figura 5.34 - Gráfico tipo Box-plot dos dados obtidos no teste de resistência ao cisalhamento dos grânulos do Inóculo.

Observa-se pela Figura 5.34 um deslocamento da média da área dos grânulos antes e depois do teste de resistência, mostrando uma diminuição da área. Também é visível uma maior variação da área medida dos grânulos após os testes, isto indica uma maior 
heterogeneidade dos grânulos submetidos à força mecânica. Tal fato se deve ao desprendimento da camada de exopolímero presente nos grânulos, sendo que alguns grânulos tiveram mais desbastamento da camada externa do que outros.

A Figura 5.35 contém as imagens utilizadas na medição da área média dos grânulos do inóculo, antes e depois do teste de resistência mecânica.

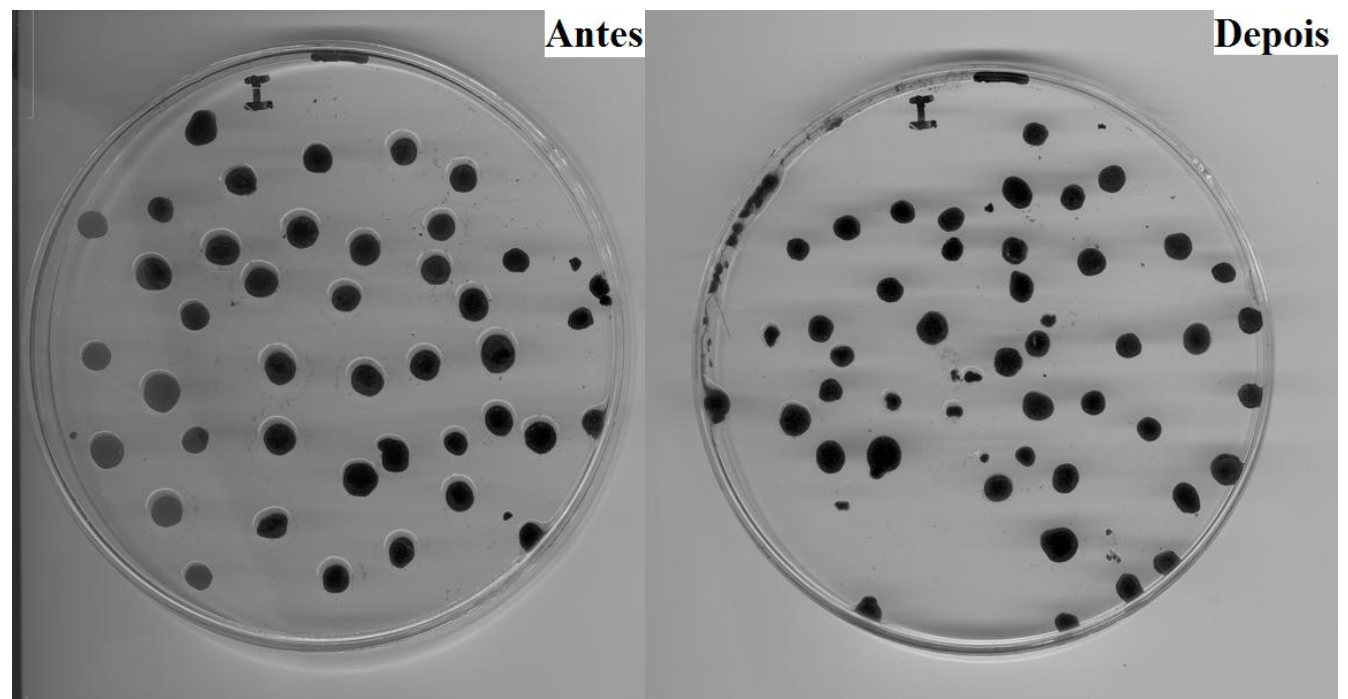

Figura 5.35 - Imagens utilizadas para medição das áreas médias dos grânulos do inóculo.

Observa-se que a placa que contém os grânulos depois do teste de resistência possui maior quantidade de pequenas partículas, indicando um desprendimento de material dos grânulos, ocasionando a diminuição da área média. Entretanto, mesmo que a diminuição das áreas médias dos grânulos do inóculo aponte que eles sejam estatisticamente diferentes, não foram observados grânulos completamente destruídos, indicando que estes grânulos são resistentes a deformações ou desintegrações.

- Reator 1

De acordo com o teste t de Student realizado para as amostras de grânulos do reator 1, foi encontrado o seguinte resultado:

- a diferença entre os valores médios dos dois grupos não é maior do que o esperado, logo, as amostras não são estatisticamente diferentes, em um nível de $95 \%$ de confiança. 


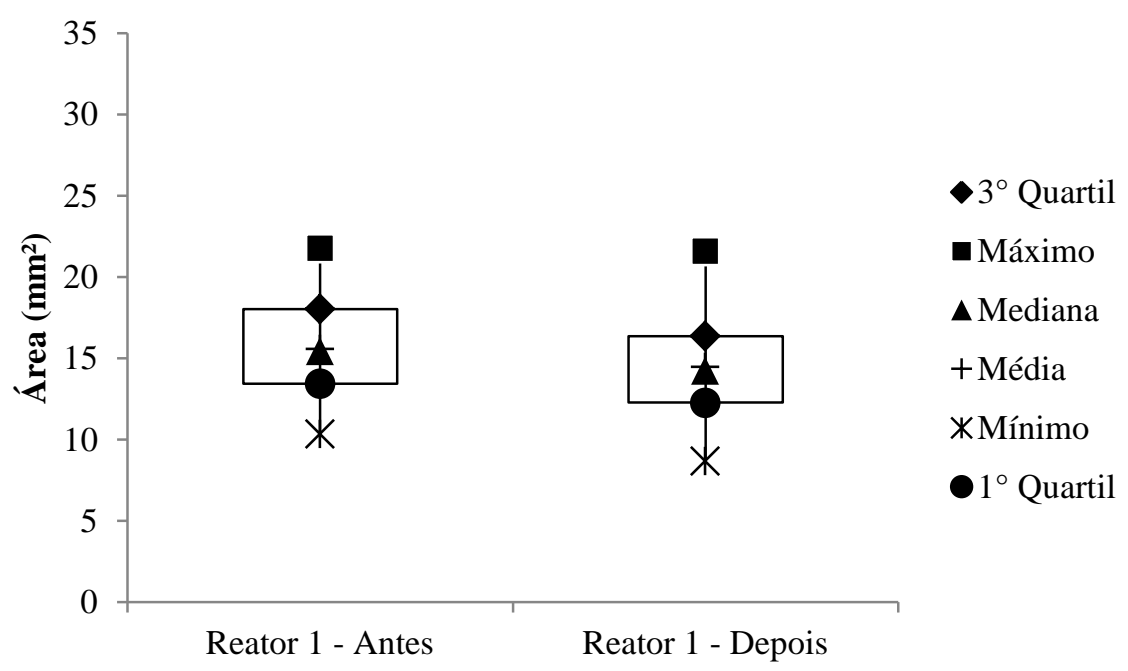

Figura 5.36 - Gráfico tipo Box-plot dos dados obtidos no teste de resistência ao cisalhamento dos grânulos do reator 1 .

Observa-se pela Figura 5.36 um pequeno deslocamento da média da área dos grânulos antes e depois do teste de resistência, mostrando que as áreas medidas foram bem próximas.

A Figura 5.37 contém as imagens utilizadas na medição da área média dos grânulos do inóculo, antes e depois do teste de resistência mecânica.

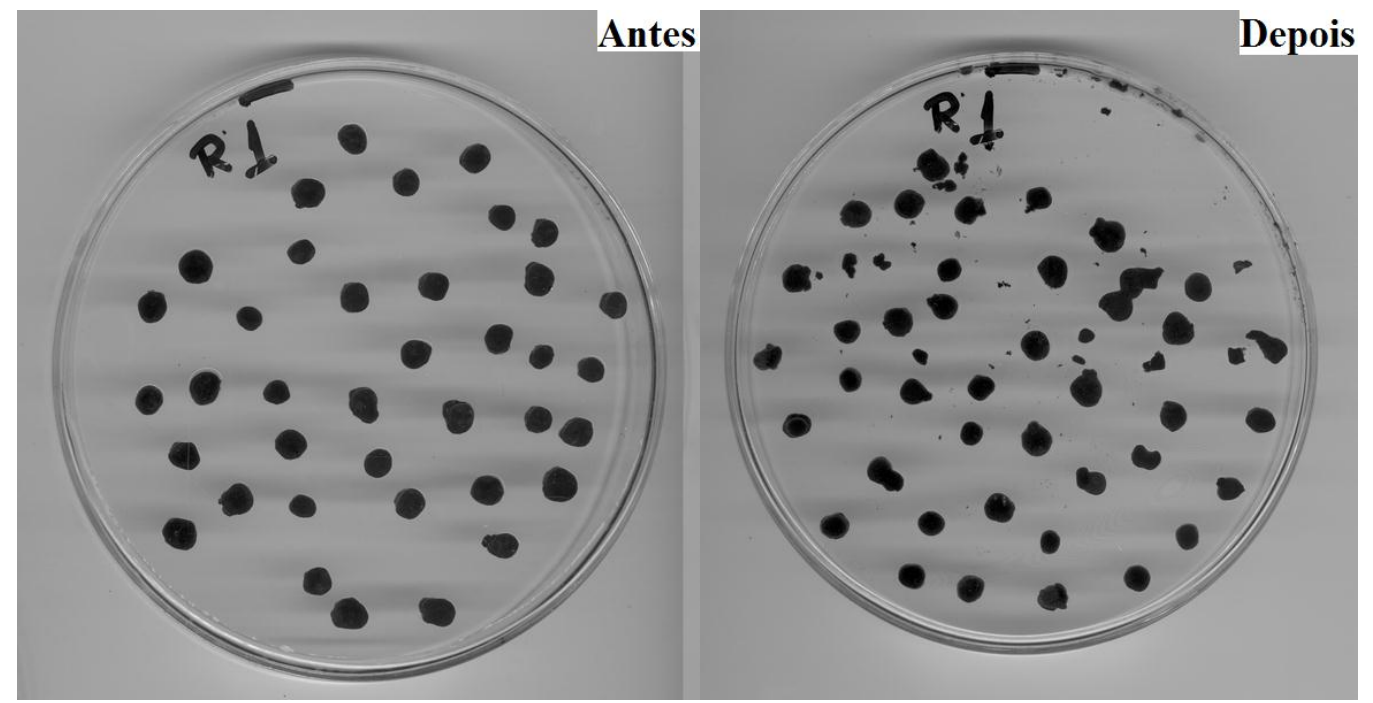

Figura 5.37 - Imagens utilizadas para medição das áreas médias dos grânulos do reator 1.

Observa-se, assim com no inóculo, que a placa que contém os grânulos depois do teste de resistência possui maior quantidade de pequenas partículas, indicando um desprendimento de material dos grânulos, ocasionando a diminuição da área média. Entretanto, a diminuição das áreas médias dos grânulos do reator 1 não foi estatisticamente 
diferente, indicando que estes grânulos são mais resistentes a deformações ou desintegrações, do que os grânulos do inóculo.

- Reator 2

De acordo com o teste t de Student realizado para as amostras de grânulos do reator 2, foi encontrado o seguinte resultado:

- a diferença entre os valores médios dos dois grupos é maior do que o esperado, logo, as amostras são estatisticamente diferentes, em um nível de 95\% de confiança.

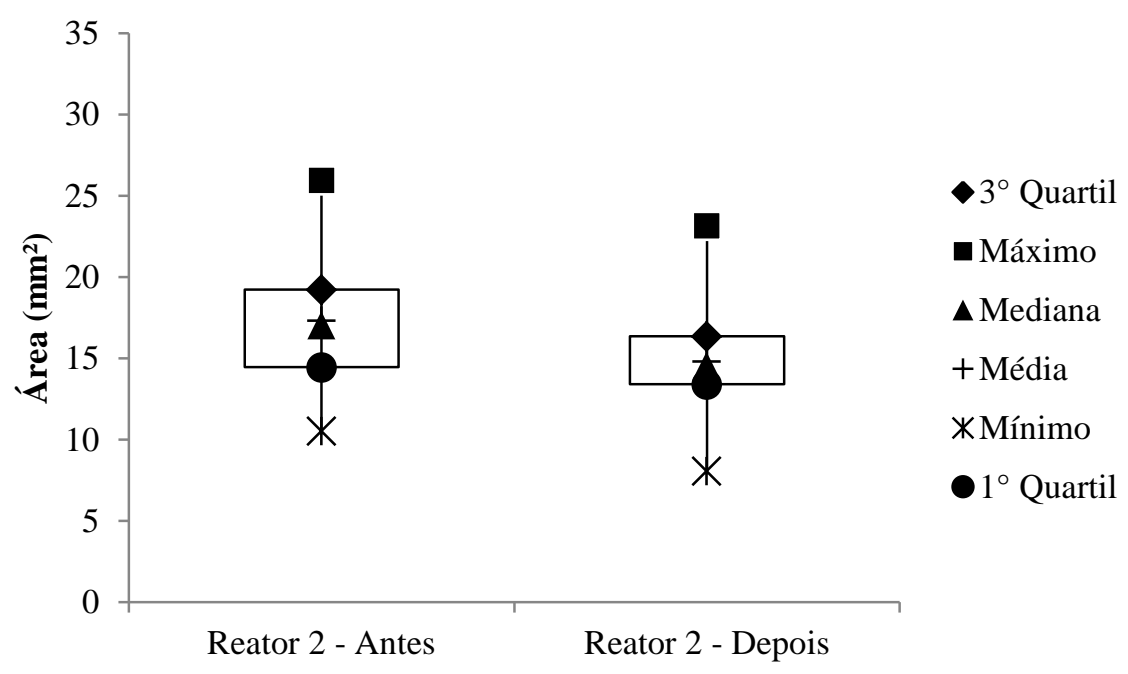

Figura 5.38 - Gráfico tipo Box-plot dos dados obtidos no teste de resistência ao cisalhamento dos grânulos do reator 2 .

Observa-se pela Figura 5.38 um deslocamento da média da área dos grânulos antes e depois do teste de resistência, mostrando uma diminuição da área. Também é visível um menor desvio padrão e uma menor variação da área medida dos grânulos após os testes, isto indica uma menor heterogeneidade dos grânulos submetidos à força mecânica. Tal fato se deve ao desprendimento da camada de exopolímero presente nos grânulos, sendo que os grânulos apresentaram desbastamento uniforme da camada externa.

A Figura 5.39 contém as imagens utilizadas na medição da área média dos grânulos do inóculo, antes e depois do teste de resistência mecânica. 


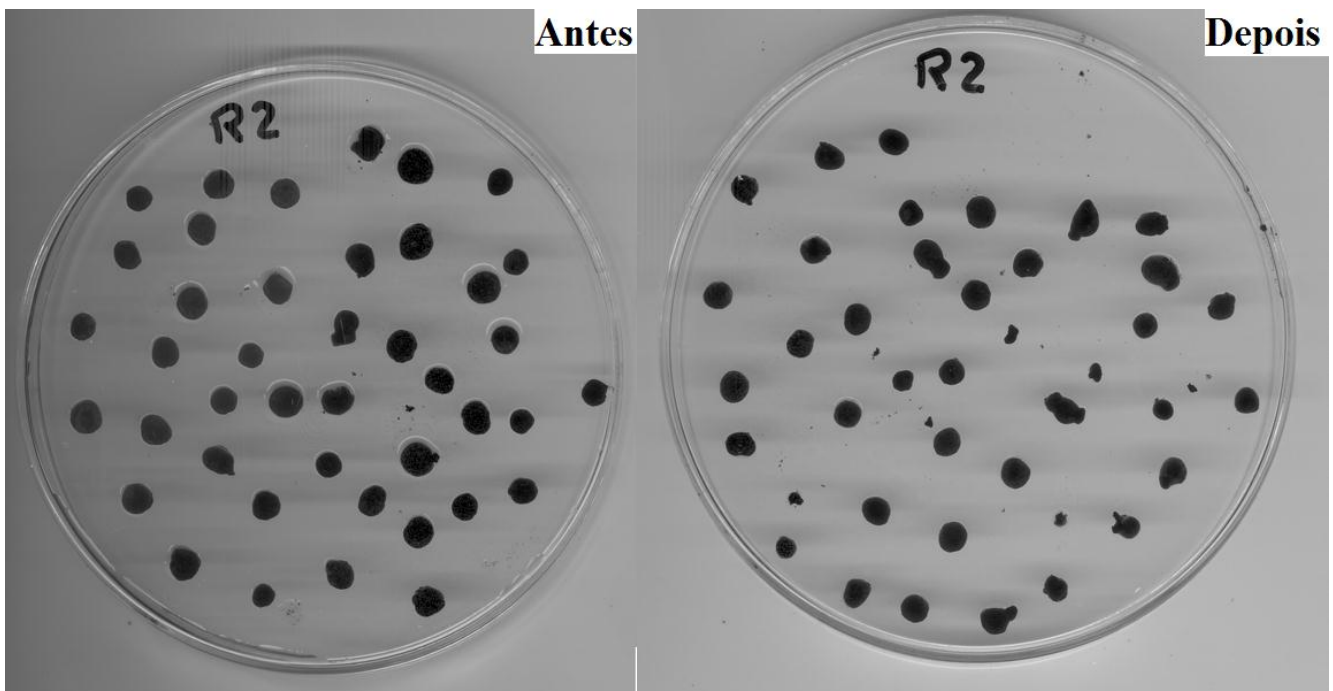

Figura 5.39 - Imagens utilizadas para medição das áreas médias dos grânulos do reator 2.

Observa-se, assim como o inóculo e o reator 1, que a placa que contém os grânulos depois do teste de resistência possui maior quantidade de pequenas partículas, indicando um desprendimento de material dos grânulos, ocasionando a diminuição da área média. Entretanto, mesmo que a diminuição das áreas médias dos grânulos do inóculo aponte que eles sejam estatisticamente diferentes, não foram observados grânulos completamente destruídos, indicando que estes grânulos são resistentes a deformações ou desintegrações.

Os resultados das análises estatísticas feitas pelo software estão apresentados no Apêndice. 


\section{CONCLUSÕES}

Baseando-se nos dados obtidos e na experiência de conduzir um monitoramento com o intuito de avaliar o efeito do biopolímero experimental no pré-tratamento da vinhaça à digestão anaeróbia, pode-se concluir que:

$\mathrm{O}$ aumento de $\mathrm{pH}$ conferido à vinhaça após a coagulação se mostrou como ponto negativo deste tratamento, considerando a etapa de processamento anaeróbio logo após o tratamento físico-químico. Para adequar a vinhaça afluente ao reator anaeróbio foi preciso corrigir o pH com ácido clorídrico, acarretando em um custo adicional ao sistema.

A coagulação da vinhaça através do biopolímero experimental como pré-tratamento ao processamento anaeróbio não se mostrou vantajosa, pois após três meses de operação notou-se uma queda brusca da eficiência de remoção de DQO, provavelmente um colapso inicial do sistema. Após o reestabelecimento das condições iniciais do tratamento anaeróbio, também foi observado uma tendência de queda da eficiência e possível colapso do sistema, ao se completar pouco mais de um mês de operação.

A produção de metano em ambos os reatores, durante as Fases I e II, esteve em concordância com a eficiência de remoção de DQO, sendo um indicar de qualidade da digestão anaeróbia. Assim, este parâmetro foi importante para indicar falhas no sistema, no caso, o reator 2 durantes as duas fases de operação.

O processamento da vinhaça, através dos reatores 1 e 2 , não apresentou indícios de que os reatores estivessem se acidificando, pois as análises de alcalinidade a bicarbonato durante toda o monitoramento indicaram valores que representam estabilidade do sistema. Com exceção do reator 2 ao fim da Fase II, que apresentou ligeira queda de pH e alta concentração de alcalinidade total, indicando uma possível acidificação.

As análises de biologia molecular indicaram similaridades entre os reatores 1 e 2 de 66,5 e 58\%, para os domínios Bacteria e Archaea, respectivamente. Desta forma, supõe-se que esta diferença da biota entre os reatores não estaria contribuindo para a falha conferida no reator 2 .

As análises de Espectrometria de Energia Dispersiva de Raios-X indicam a presença do elemento cálcio com aproximadamente $22 \%$ para o inóculo, 39\% para o reator 1 e $50 \%$ para o reator 2 da massa dos elementos analisados das amostras de grânulos. Em conjunto com as micrografias realizadas por meio de Microscopia Eletrônica de Varredura puderam-se 
observar depósitos de algum tipo de composto na superfície dos grânulos adaptados para a vinhaça, principalmente nas amostras do reator 2. Há indícios de que estes depósitos sejam de compostos providos de cálcio, e que estes estejam interferindo na capacidade de assimilação de substrato por parte da biota presente na estrutura granular, sendo esta a possível causa da falha no reator 2. Desta forma, o cálcio estaria agindo como composto inibidor da digestão anaeróbia.

Os testes de resistência mecânica dos grânulos indicam que os grânulos contidos no inóculo, reatores 1 e 2 possuem resistência à desintegração.

Em uma análise global sobre a conduta deste experimento, pode-se concluir que o uso de um biopolímero à base de cálcio como coagulante em um pré-tratamento ao processamento anaeróbio de vinhaça não foi benéfico, portanto, não recomendado. 


\section{REFERÊNCIAS BIBLIOGÁFICAS}

ALVES, R. G. C. M. E. A. Digestores anaeróbios para tratamento de dejetos suínos avaliação de partida para diferentes configurações de reatores. In: 23 CONG. BRAS. ENG. SANITÁRIA E AMBIENTAL, Anais., Campo Grande, 2005.

APHA. Standard Methods for the Examination of Water and Wastewater, 2005. 20th edition.

AQUINO, S. F. et al. METODOLOGIAS PARA DETERMINAÇÃO DA ATIVIDADE METANOGÊNICA (AME) ESPECÍFICA EM LODOS ANAERÓBIOS. Engenharia Sanitária e Ambiental, v. 12, n. 2, p. 192-201, abr/jun 2007.

BONGIOVANI, M. C. et al. Os benefícios da utilização de coagulantes naturais para a obtenção de água potável. Acta Scientiarum. Technology, Maringá, 2010. 167-170.

BRITZ, T. J.; VAN DER MERWE, M.; RIEDEL, K.-H. Influence of phenol additions on the efficiency of an anaerobic hybrid digester treating landfill leachate. Biotechnology Letters, 1992. 14:323-8.

BROWN, A. Y. T. et al. Influência do Carregamento Orgânico, hidrárulico e recirculação sobre o desempenho de reator UASB empregado no tratamento da vinhaça. $\mathbf{X}$ Latin American Workshop and Symposium on Anaerobic Digestion, Ouro Preto, October 2011.

CABELlO, P. E.; SCOGNAMIGLIO, F. P.; TERÁN, F. J. C. TRATAMENTO DE VINHAÇA EM REATOR ANAERÓBIO DE LEITO FLUIDIZADO. Engenharia Ambiental (online), Espírito Santo do Pinhal, jan/abr 2009. v.6, n.1, p.321-338.

CAMBUIM, F. A. A ação da vinhaça sobre a retenção de umidade, pH, acidez total, acumulação e lixiviação de nutrientes, em solo arenoso., Universidade Federal Rural de Pernambuco - Dissertação de Mestrado - Recife, 1983. 133.

CAMILO, R. et al. Avaliação da Potencialidade de Geração de Energia Elétrica pela Biodegradação Anaeróbia da Vinhaça em Reator UASB. $\mathbf{2 4}^{\circ}$ Congresso Brasileiro de Engenharia Sanitária e Ambiental , Belo Horizonte, Setembro 2007.

CENTURIÓN, R. E. B. et al. Destinação final da vinhaça produzida por destilarias autônomas e anexas, enquadradas no programa nacional do álcool. In: Congresso Brasileiro de Engenharia Sanitária, Fortaleza, novembro 1989. 07.

CHERNICHARO, C. A. D. L. REATORES ANAERÓBIOS. 2. ed. Belo Horizonte: Ed. UFMG, 2008.

CONAB. Acompanhamento de safra brasileira : cana-de-açúcar, segundo levantamento, agosto 2011. Companhia Nacional de Abastecimento. Brasília, p. 19. 2011.

COPERSUCAR. Aproveitamento da vinhaça, viabilidade técnica-econômica.. Centro de Tecnologia da Cooperativa Central dos Produtores de Açúcar e Álcool do Estado de São Paulo. Piracicaba. 1979. 
CORAZZA, R. I. Reflexões sobre o papel das políticas ambientais e de ciência e tecnologia na modelagem de opções produtivas 'mais limpas' numa perspectiva evolucionista: um estudo sobre o problema da disposição da vinhaça. In: III Encontro Nacional da Sociedade Brasileira de Economia Ecológica, Refice, 1999. p.18.

CORAZZA, R. I.; SALLES-FILHO, S. L. M. Opções produtivas mais limpas: uma perspectiva evolucionista a partir de um estudo de trajetória tecnológica na agroindústria canavieira. XXI SIMPÓSIO DE GESTÃO DA INOVAÇÃO TECNOLÓGICA , São Paulo, 7 - 10 Novembro 2000. 15.

CRAVEIRO, A. M. Desempenho e estudos cinéticos de biodigestores híbridos com diferentes porcentagens de enchimento. Tese (doutorado), São Paulo - Escola Politécnica Universidade de São Paulo, 1994.

CRUZ, R. L. Efeito da aplicação de vinhaça sobre o solo e água subterrânea. EESC-USP. Dissertação (Mestrado) - São Carlos. 1991.

DEFOUR, D. et al. Field experience with different system for biomass accumulation in anaerobic reactor technology. Water Science \& Technology, 30: 12,181-191., 1994.

DIAS, J. et al. COMPORTAMENTO DO pH E DA ALCALINIDADE NO PROCESSO DE DIGESTÃO ANAERÓBIA DE EFLUENTES OLEOSOS. $1^{\circ}$ Encontro Nacional de Tecnologia Química, Fortaleza, 9-11 Julho 2008.

DUARTE, I. C. S. Caracterização microbiológica da remoção e degradação de alquilbenzeno linear sulfonado (LAS) em reatores anaeróbios com biofilme e células planctônicas. Tese (Doutorado) - Escola de Engenharia de São Carlos, Universidade de São Paulo. São Carlos. 2006.

FREITAS, G. L. D. USO DA ÁGUA NO PROCESSO de PRODUÇÃo DE ÁlCOOL: ESTUDO DE CASO. Trabalho de Conclusão de Curso. (Graduação em Engenharia Ambiental) - Universidade Católica de Goiás. Orientador: Osmar Mendes Ferreira. Goiânia, p. 20.2006.

GONÇALVES, C. A. S.; SILVA, E. L. TRATAMENTO FÍSICO-QUÍMICO DA VINHAÇA. XXVII Congresso Interamericano de Engenharia Sanitária e Ambiental, Porto Alegre, Dezembro 2000. p.8.

GOODALL, D. W. A New Similarity Index Based on Probability. Biometrics, 1966. v. 22, n. 4, p. 882-907.

GRANATO, E. F. GERAÇÃO DE ENERGIA ATRAVÉS DA BIODIGESTÃo ANAERÓBICA DA VINHAÇA. Dissertação (Mestrado) - Faculdade de Engenharia, Campus de Bauru, Universidade Estadual Paulista. Bauru, p. p.103. 2003.

GRIFFITHS, R. I. et al. Rapid method for coextraction of DNA and RNA from natural environments for analysis of ribosomal DNA and rRNA-based microbial community compositon. Applied and Environmental Microbiology. 66:5488-5491. 
GUIOT, S. R. E. V. D. B. Performance and biomass retention of upflow anaerobic reactor combining a sludge blanket and a filter. Biotechnology Letters, v. 6, p. 161 - 164, 1984.

HIRASAWA, J. S. Avaliação da comunidade microbiana anaeróbia em reator sulfetogênico utilizando a hibridação in situ com sondas fluorescentes (FISH). Dissertação (Mestrado) - Escola de Engenharia de São Carlos, Universidade de São Paulo. São Carlos, p. 82. 2003.

HIRASAWA, J. S. Avaliação da metanogênese e sulfetogênese na presença de oxigênio, sob diferentes relações etanol/sulfato, utilizando técnicas de Biologia Molecular. Tese (Doutorado) - Escola de Engenharia de São Carlos, Universidade de São Paulo. São Carlos. 2007.

IVESTE SP. Agência Paulista de Investimentos e Competitividade, 2011. Disponivel em: <http://www.investe.sp.gov.br>. Acesso em: 27 janeiro 2012.

JIMÉNEZ, A. M.; BORJA, R.; MARTÍN, A. Aerobic-anaerobic biodegradation of beet molasses alcoholic fermentation wastewater. Process Biochemistry, 2003. 38:1275-1284.

KUDO, Y. et al. Methanogen flora of paddy soils in Japan. FEMS Microbiology Ecology, 1997. 23:39-48.

LENS, P. N. L. et al. Perspectives of sulfate reducing bioreactors in environmental biotechnology. Environmental Science \& Bio/Technology, 2002. 1: 311-325.

LOPES, P. D. R.; RIBEIRO, C. L. J.; TERAN, F. J. C. ESTUDO DO DESEMPENHO DE UM SISTEMA HÍBRIDO NO TRATAMENTO DE ESGOTO SANITÁRIO. HOLOS Environment, v. 9, n. 2, p. 202-218, 2009. ISSN ISSN:1519-8634 (ON-LINE).

LYRA, M. R. C. C.; ROLIM, M. M.; SILVA, J. A. A. D. Toposseqüência de solos fertigados com vinhaça: contribuição para a qualidade das águas do lençol freático. Revista Brasileira de Engenharia Agrícola e Ambiental, Campina Grande, PB, 15 Outubro 2003. v.7, n.3, p.525-532.

MACHADO, O. J.; FREIRE, F. B. Tratamento de Vinhaça em Reator Anaeróbio de Fluxo Ascendente e Manta de Lodo. IV Semana do Meio Ambiente da Universidade Tecnológica Federal do Paraná / Campo Mourão , OLAM - Ciência \& Tecnologia, Rio Claro, SP, Brasil, Setembro 2009. n.2, n. especial, p.170-188.

MAXHAM, J. V.; WAKAMIYA, W. Innovative biological wastewater treatment technologies applied to the treatment for biomass gasification wastewater.. In: Proceedings of 35th conference, Purdue University, 80-94., 1981.

METCALF; EDDY. Wastewater engineering: treatment, disposal and reuse. 4. ed. New York: McGraw-Hill. 1334p., 2003.

MUYZER, G.; RAMSING, N. B. Molecular methods to study the organization of microbial communities. Water Science and technology, 1995. 32(8):1-9. 
PEARSON, F.; SHIUN-CHUNG, C.; GAUTIER, M. Toxic inhibition of anaerobic biodegradation. Journal of Water Pollution Control Federation, 1980. 52:472-82.

PEREBOOM, J. H. F. Strength Characterisation of Microbial Granules. Water Science and Technology, v. 36. No. 6-7, p. 141-148, 1997.

PEREIRA-RAMIREZ, O. et al. INFLUÊNCIA DA RECIRCULAÇÃO E DA ALCALINIDADE NO DESEMPENHO DE UM REATOR UASB NO TRATAMENTO DE EFLUENTE DE SUINOCULTURA. Revista Brasileira de Agrociência, v. 10 - n. 1, p. 103110, jan-mar 2004.

PINTO, C. P. Tecnologia da Digestão Anaeróbia da Vinhaça e Desenvolvimento Sustentável. Dissertação (Mestrado) - Faculdade de Engenharia Mecânica - Universidade Estadual de Campinas. Campinas, p. 145. 1999.

POMPERMAYER, R. S.; PAULA JR, D. R. Estimativa do potencial brasileiro de produção de biogás através da biodigestão da vinhaça e comparação com outros energéticos. Anais - 3. Encontro de. Energia no Meio Rural, Setembro. 2000.

POSTGATE, J. R. The sulphate-reducing bacteria. $2^{\text {a }}$ Ed. 2. ed. 208p. London: Cambridge University, 1984.

RAPHAEL, E. G. et al. DEGRADAÇÃO FOTOCATALÍTICA DE VINHAÇA: AVALIAÇÃO DE CATALISADORES. VIII Congresso Brasileiro de Engenharia Química em Iniciação Científica , Uberlândia, Julho 2009. p.7.

RIBAS, M. M. F. Tratamento de Vinhaça em Reator Anaeróbio Operado em Batelada Sequencial Contendo Biomassa Imobilizada Sob Condições Termofílicas e Mesofílicas. Tese (Doutorado) - Escola de Engenharia de São Carlos, Universidade de São Paulo. São Carlos. 2006.

ROCHA, M. A. G. . E. A. Avaliação e comparação entre a atividade metanogênica específi ca de esgotos doméstico e industrial.,. In: ANAIS $21^{\circ}$ CONGRESSO BRASILEIRO DE ENG. SANITÁria E AMBIENTAL, J. Pessoa, 2001.

ROSSETTO, A. J. Utilização Agronômica Dos Subprodutos E Resíduos Da Indústria Açucareira E Alcooleira. Paranhos, S.B. (ed.). Cana-de-açúcar: cultivo e utilização, Campinas: Fundação Cargill, 1987. 435-504.

SAAVEDRA, N. K. Avaliação de bactérias fototróficas em lagoas de estabilização: diversidade, purificação e identificação. Tese (Doutorado) - Escola de Engenharia de São Carlos, Universidade de São Paulo. São Carlos. 2007.

SAKAMOTO, I. K. et al. Avaliação da comunidade microbiana do domínio Bacteria e Archaea em reatores anaeróbios tratando esgoto sanitário. Anais do IV Seminário do Projeto Temático Fapesp: "Desenvolvimento, análise, aprimoramento e otimização de reatores anaeróbios para tratamento de águas residuárias", EESC/USP - São Carlos,SP, p. 336-345, 2005. 
SANTIAGO, R. M.; GIRARDI, F.; GIMENES, M. L. TRATAMENTO DE VINHAÇA COM OS COAGULANTES NATURAIS: QUITOSANA, TANINO E MORINGA. VIII Congresso Brasileiro de Engenharia Química em Iniciação Científica, Uberlândia, Julho 2009. 6 - www.cobeqic2009.feq.ufu.br/uploads/media/89620731.pdf - Acesso em 04/02/2011.

SANTOS, M. B. D. Proposta Metodológica para o Planejamento do Uso Agrícola da Vinhaça, Considerando Seus Aaspectos Ambientais, por Meio de Sistemas de Informação Geográfica. Dissertação (Mestrado) - Escola de Engenharia de São Carlos, Universidade de São Paulo. São Carlos, p. p.123. 2000.

SAPLA, R. B. Tratamento físico-químico da vinhaça de destilaria de etanol de cana-deaçúcar com biopolímero experimental. Dissertação (Mestrado) - Escola de Engenharia de São Carlos. Universidade de São Paulo. São Carlos (Em elaboração). 2012.

SARTI, et al. TRATAMENTO DE ESGOTO SANITÁRIO UTILIZANDO REATORES ANAERÓBIOS OPERADOS EM BATELADAS SEQUENCIAIS (ESCALA PILOTO). Engenharia Sanitária e Ambiental, jan/mar 2006. 73-82.

SILVA, G. M. A.; ORLANDO FILHO, J. Carcterização da Composição Química dos Diferentes Tipos de Vinhaça do Brasil. Boletim Técnico Planalsucar, 1981. v.8, p.5-22.

SILVA, M. A. S. D.; GRIEBELER, N. P.; BORGES, L. C. Uso de vinhaça e impactos nas propriedades do solo e do lençol freático. Revista Brasileira de Engenharia Agrícola e Ambiental, Campina Grande, PB, 25 Outubro 2007. v.11, n.1, p.108-114.

SMA. Secretaria do Meio Ambiente, 2012. Disponivel em: <http://www.ambiente.sp.gov.br/>. Acesso em: 27 janeiro 2012.

SOUZA, P. H. T. D. O. E. Rede neural artificial para monitoramento em tempo real da concentração de potássio na vinhaça in natura. Dissertação (Mestrado) - Escola de Engenharia de São Carlos, Universidade de São Paulo. São Carlos, p. 85. 2010.

SPEECE, R. E. Anaerobic Biotechnology for Industrial Wastewaters. Nashville: Tennesse, 1996.

SUBTIL, E. L. Avaliação da redução de sulfato e produção de sulfeto dissolvido em reator anaeróbio de manta de lodo (UASB) tratando esgoto sanitário em escala real. Centro Tecnológico, Universidade Federal do Espírito Santo. Dissertação (Mestrado) - Vitória - ES, p. 100. 2007.

TOLEDO, L. R. Energia Reciclada \& Máquinas para Acelerar o Tempo. TECNOLOGIA/PESQUISA - STAB, 2001. vol.33 - p.43-47.

UDOP. União dos Produtores de Bioenergia, 2012. Disponivel em: 〈www.udop.com.br〉. Acesso em: 27 janeiro 2012.

UNICA. União da Indústria de Cana-de-Açúcar, 2012. Disponivel em: <http://www.unica.com.br>. Acesso em: 28 Janeiro 2012. 
VAN LANGERAK, E. P. A. et al. Effects Of High Calcium Concentrations On The Development Of Methanogenic Sludge In Upflow Anaerobic Sludge Bed (UASB) Reactors. Wat. Res., Great Britain, v. 32 no. 4, p. 1255-1263, 1998.

VIANA, A. B. Tratamento anaeróbio de vinhaça em reator UASB operado em temperatura na faixa termofílica $\left(5^{\circ} \mathrm{c}\right)$ e submetido ao aumento progressivo de carga orgânica. Dissertação (Mestrado). Escola de Engenharia de São Carlos, Universidade de São Paulo. São Carlos, p. 102. 2006.

VIEIRA, M. C. A. Setor Sucroalcooleiro Brasileiro: Evolução e Perspectivas. BNDES. Rio de Janeiro, p. 209-245. 2007.

VON SPERLING, M. Introdução à qualidade das águas e ao tratamento de esgotos. 3. ed. Belo Horizonte: UFMG, v. I, 2005.

WILKIE, A. C.; RIEDESEL, K. J.; OWENS, J.. Stillage characterization and anaerobic treatment of ethanol stillage from conventional and cellulosic feedstocks. Biomass and Bioenergy, 2000. p.63-102. 


\section{APÊNDICE}

Neste item são demonstrados os resultados emitidos pelo software SigmaStat 3.5 para cada análise estatística realizada nesta pesquisa.

\subsection{Comparativo entre as eficiências de remoção de DQO dos reatores 1 e 2 (Item 5.5)}

t-test

Friday, March 30, 2012, 08:27:56

Data source: Data 1 in Dados Gerais

Normality Test: $\quad$ Failed $(\mathrm{P}<0,050)$

Test execution ended by user request, Rank Sum Test begun

Mann-Whitney Rank Sum Test

Friday, March 30, 2012, 08:27:56

Data source: Data 1 in Dados Gerais

$\begin{array}{lccccc}\text { Group } & \text { N } & \text { Missing } & \text { Median } & \mathbf{2 5 \%} & \mathbf{7 5 \%} \\ \text { Eficiencia R1 } & 20 & 0 & 83,943 & 79,028 & 87,103 \\ \text { Eficiencia R2 } & 20 & 0 & 80,687 & 74,174 & 87,644\end{array}$

Mann-Whitney U Statistic $=174,000$

$\mathrm{T}=436,000 \mathrm{n}($ small $)=20 \mathrm{n}(\mathrm{big})=20(\mathrm{P}=0,490)$

The difference in the median values between the two groups is not great enough to exclude the possibility that the difference is due to random sampling variability; there is not a statistically significant difference $(P=0,490)$ 
8.2. Comparativo entre as áreas dos grânulos do inóculo no teste de resistência mecânica ao cisalhamento (item 5.6.3.1)

t-test sexta-feira, março 30, 2012, 11:38:31

Data source: Data 1 in Notebook 1

Normality Test: $\quad$ Passed $(P=0,331)$

Equal Variance Test: $\quad$ Passed $(\mathrm{P}=0,848)$

$\begin{array}{lccccc}\text { Group Name } & \text { N } & \text { Missing } & \text { Mean } & \text { Std Dev } & \text { SEM } \\ \text { Inóculo - Antes } & 39 & 0 & 19,210 & 4,224 & 0,676 \\ \text { Inóculo - Depois } & 39 & 0 & 15,632 & 4,257 & 0,682\end{array}$

Difference $\quad 3,578$

$t=3,725$ with 76 degrees of freedom. $(\mathrm{P}=<0,001)$

95 percent confidence interval for difference of means: 1,665 to 5,490

The difference in the mean values of the two groups is greater than would be expected by chance; there is a statistically significant difference between the input groups $(\mathrm{P}=<0,001)$.

Power of performed test with alpha $=0,050: 0,959$ 


\subsection{Comparativo entre as áreas dos grânulos do reator 1 no teste de resistência mecânica ao cisalhamento (item 5.6.3.1)}

t-test

Data source: Data 1 in Notebook 1

Normality Test: $\quad$ Passed $(\mathrm{P}=0,582)$

Equal Variance Test: $\quad$ Passed $(\mathrm{P}=0,675)$

$\begin{array}{lccccc}\text { Group Name } & \text { N } & \text { Missing } & \text { Mean } & \text { Std Dev } & \text { SEM } \\ \text { Reator 1 - Antes } & 38 & 0 & 15,582 & 2,987 & 0,485 \\ \text { Reator 1 - Depois } & 42 & 0 & 14,479 & 3,192 & 0,493\end{array}$

Difference $\quad 1,104$

$\mathrm{t}=1,592$ with 78 degrees of freedom. $(\mathrm{P}=0,115)$

95 percent confidence interval for difference of means: $-0,277$ to 2,484

The difference in the mean values of the two groups is not great enough to reject the possibility that the difference is due to random sampling variability. There is not a statistically significant difference between the input groups $(\mathrm{P}=0,115)$.

Power of performed test with alpha $=0,050: 0,216$

The power of the performed test $(0,216)$ is below the desired power of 0,800 .

Less than desired power indicates you are less likely to detect a difference when one actually exists. Negative results should be interpreted cautiously. 
8.4. Comparativo entre as áreas dos grânulos do reator 2 no teste de resistência mecânica ao cisalhamento (item 5.6.3.1)

t-test sexta-feira, março 30, 2012, 11:39:27

Data source: Data 1 in Notebook 1

Normality Test: $\quad$ Passed $(P=0,464)$

Equal Variance Test: $\quad$ Passed $(\mathrm{P}=0,440)$

$\begin{array}{lccccc}\text { Group Name } & \text { N } & \text { Missing } & \text { Mean } & \text { Std Dev } & \text { SEM } \\ \text { Reator 2 - Antes } & 42 & 0 & 17,312 & 3,549 & 0,548 \\ \text { Reator 2 - Depois } & 36 & 0 & 14,801 & 3,378 & 0,563\end{array}$

Difference $\quad 2,510$

$t=3,184$ with 76 degrees of freedom. $(P=0,002)$

95 percent confidence interval for difference of means: 0,940 to 4,081

The difference in the mean values of the two groups is greater than would be expected by chance; there is a statistically significant difference between the input groups $(\mathrm{P}=0,002)$.

Power of performed test with alpha $=0,050: 0,865$ 